LBNL-63557

\title{
HYDROGEOLOGY AND TRITIUM TRANSPORT IN CHICKEN CREEK CANYON, LAWRENCE BERKELEY NATIONAL LABORATORY, BERKELEY, CALIFORNIA
}

\author{
Preston D. Jordan \\ Iraj Javandel \\ Earth Sciences Division \\ Lawrence Berkeley National Laboratory
}

October, 2007

The work in this report was a part of Lawrence Berkeley National Laboratory's Environmental Restoration Program, which was supported by the Office of Environmental Management of the U.S.

Department of Energy. Lawrence Berkeley National Laboratory is operated by the University of California for the U. S. Department of Energy under contract DE-AC02-05CH11231. 
This page intentionally left blank. 


\section{TABLE OF CONTENTS}

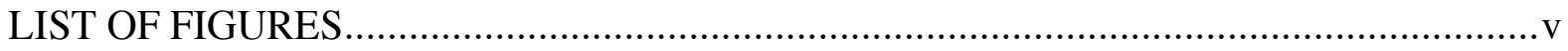

ABBREVIATIONS AND ACRONYMS ................................................................ vii

ACKNOWLEDGMENTS ...................................................................................

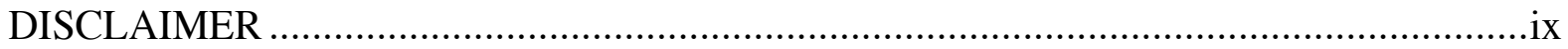

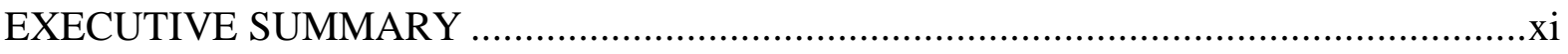

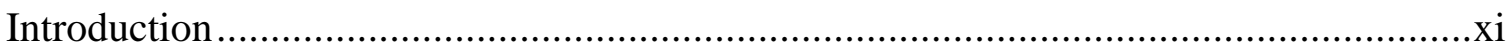

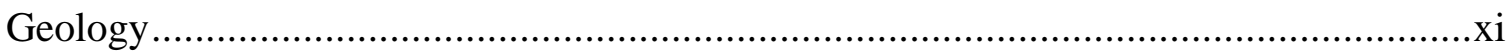

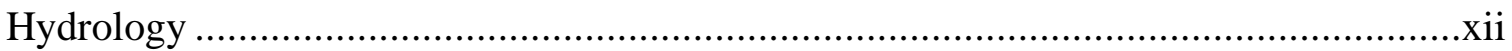

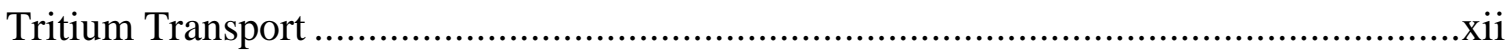

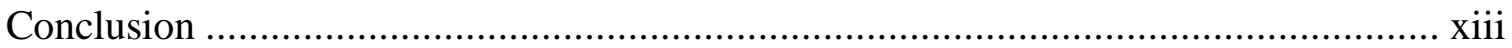

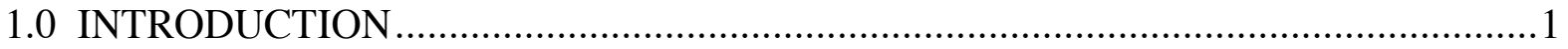

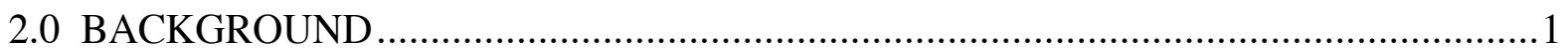

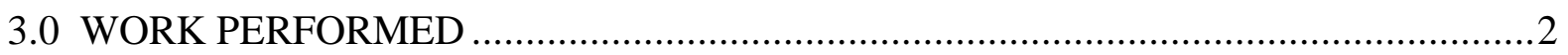

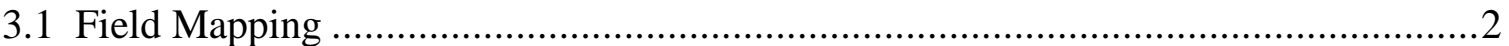

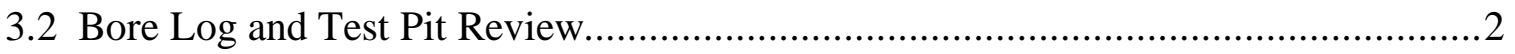

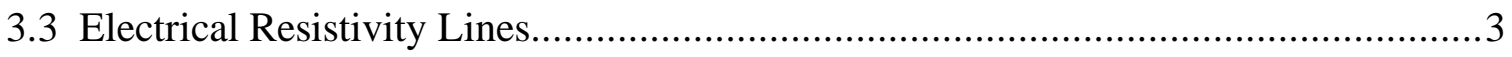

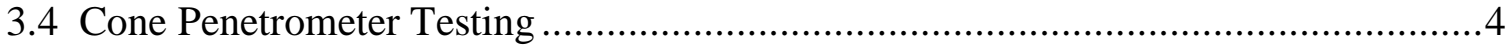

3.5 Auger Drilling and Temporary Well Installation .......................................... 4

3.6 Drain Outfall, Creek and Seep Sampling............................................................5

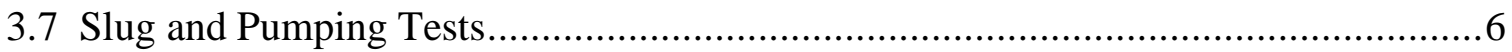

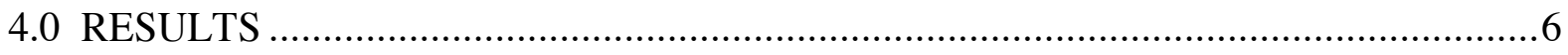

4.1 Undivided Quaternary Soil Distribution ........................................................ 6

4.2 Bedrock in Chicken Creek Canyon .................................................................... 8

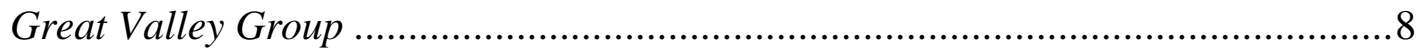

Great Valley Group/Orinda Formation Fault Contact ........................................8

Orinda Formation ........................................................................................ 9

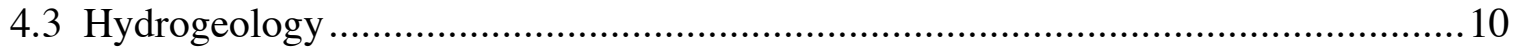

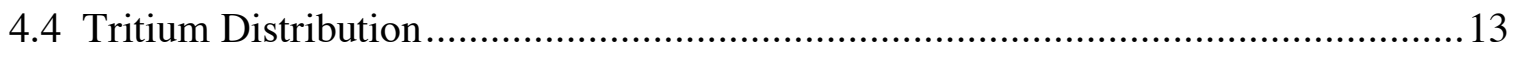

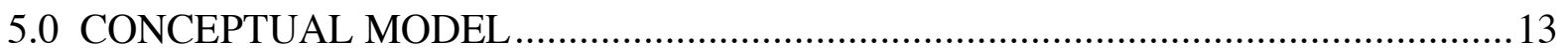

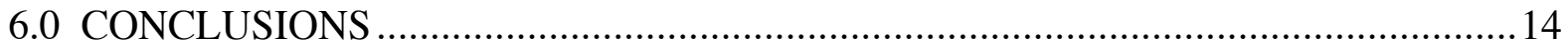

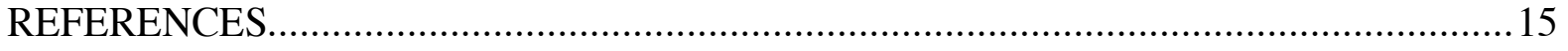

APPENDIX 1: Resistivity Profiles

APPENDIX 2: Cone Penetrometer Test Logs

APPENDIX 3: Boring Logs for Temporary Groundwater Sampling Points SB31-02-1 to SB31-02-7 and SB64-03-1 to SB64-03-4 
This page intentionally left blank. 


\section{LIST OF FIGURES}

Figure 1-1. Location of study area.

Figure 2-1. Location of the tritium plume based upon 3rd quarter, 2002 results.

Figure 3-1. Map of bedrock exposures in upper Chicken Creek Canyon.

Figure 3-2a. Borings and test pits in Chicken Creek Canyon.

Figure 3-2b. Borings, test pits, and cone penetrometer tests in the northwestern portion of upper Chicken Creek Canyon.

Figure 3-2c. Borings and test pits in the central lower portion of Chicken Creek Canyon.

Figure 3-3. Electrical resistivity lines and previous borings in upper Chicken Creek Canyon shown. Resistivity anomalies shown with initial interpretation of geologic structure.

Figure 3-4. Potential sand body trends based upon electrical resistivity lines. Cone penetrometer test locations shown.

Figure 3-5. Tritium activities ( $\mathrm{pCi} / \mathrm{L}$ ) in surface water samples from drain outfalls, Chicken Creek and a seep in upper Chicken Creek Canyon. "ND" indicates no tritium detected.

Figure 3-6. Drawdowns at the end of the October 21, 2002 pump test.

Figure 4-1a. Isopach map of undivided Quaternary soil deposits in Chicken Creek Canyon.

Figure 4-1b. Isopach map of undivided Quaternary soil deposits in upper Chicken Creek Canyon.

Figure 4-2a. Structure map of the top of bedrock in Chicken Creek Canyon. Contouring includes the top of bedrock elevation along the east bank of Chicken Creek.

Figure 4-2b. Structure map of the top of bedrock in upper Chicken Creek Canyon. Contouring includes the top of bedrock elevation along the east bank of Chicken Creek.

Figure 4-3. Borings that encountered coarse-grained soils within the Quaternary soil deposits shown in green along with descriptions of the coarse-grained soils. Some, but not all, sites not encountering only fine-grained soils are shown.

Figure 4-4. Bedrock geology in upper Chicken Creek Canyon with top of bedrock structure map. The key to the bedrock units is in the caption for Figure 4-5. The heavy line represents a fault; the dashed line is an approximately located geologic contact. Stippling represents likely fault-sheared Kgv.

Figure 4-5. Section A-A' with April, 2003, water table. Qf = artificial fill, Qu = natural soil deposits, QTls $(\mathrm{o})=$ paleolandslide deposits derived from the Orinda Formation, To = Orinda Formation, Kgv = Great Valley Group. The heavy line represents a fault; dashed lines represent approximately located contacts. 
Figure 4-6. Section B-B' with April, 2003, water table. The key to the geologic units is in the caption for Figure 4-5. The heavy line represents a fault; the dotted line represents a possible anticline.

Figure 4-7. Variation of hydraulic conductivity in the Great Valley Group with distance from the Great Valley Group/Orinda Formation contact.

Figure 4-8. Water table in western upper Chicken Creek Canyon using April, 2003, water levels. Bedrock geology shown. Water surface elevation in creek at base flow used for contouring. Water level with asterisk not used for contouring.

Figure 4-9. Hydrographs for SB31-02-6 and SB31-03-3.

Figure 4-10. Hydrographs for SB31-03-1, SB31-03-2 and SB31-03-4.

Figure 4-11. Hydrographs for MW31-97-17 and nearby wells with daily precipitation overlain.

Figure 4-12. Groundwater tritium activities (pCi/L) in upper Chicken Creek Canyon in the fourth quarter, fiscal year 2003 (July through September, 2003). Bedrock geology shown. "ND" indicates no tritium detected.

Figure 4-13. Groundwater tritium activities and water table elevation in MW31-97-17.

Figure 4-14. Hydrograph for MW77-97-11 with the top of the Orinda Formation shown.

Figure 5-1. A plan view of the conceptual model of groundwater flow in upper Chicken Creek Canyon. Bedrock contacts and April, 2003, water table shown along with fourth quarter, fiscal year 2003 groundwater and February, 2003 surface water tritium activities. "ND" indicates no tritium detected.

Figure 5-2. A cross-section view of the conceptual model of groundwater flow in upper Chicken Creek Bedrock. Geologic contacts and April, 2003, water table shown. The key to the geologic units is in the caption for Figure 4-5. The heavy line represents a fault; the dotted line represents a possible anticline. 


\section{ABBREVIATIONS AND ACRONYMS}

bgs

below ground surface

CPT cone penetration test

ERP Environmental Restoration Program

LBNL Lawrence Berkeley National Laboratory

MCL Maximum Contaminant Level

$\mathrm{m} / \mathrm{s} \quad$ meters/second

NTLF National Tritium Labeling Facility

$\mathrm{pCi} / \mathrm{L} \quad$ picocuries/liter

USCS Unified Soil Classification System 
This page intentionally left blank. 


\section{ACKNOWLEDGMENTS}

The LBNL Environmental Restoration Program (ERP) staff contributed greatly to collecting the data upon which the findings of this report are based. Jim Chiu, Steve Louie and Henry Pietropaoli developed the wells, manually measured hundreds of water levels and collected tens of water samples. Jim Chiu conducted the pumping tests. Chao Shan collected water level data via pressure transducers and data loggers. David Baskin provided useful suggestions for streamlining this report. David Diamond contributed to the understanding of the overall geologic framework of the Laboratory through his work on previous reports for the ERP as well as through numerous conversations. This understanding was critical to the authors' development of the geologic findings in this report. The authors thank all of these individuals for their contributions, and for their long service to the ERP. Reviews by Stefan Finsterle and Karsten Pruess resulted in greater clarity in the description of the context for this report as well as many other improvements. Of course, all of the conclusions in this report are the sole responsibility of the authors.

\section{DISCLAIMER}

This document was prepared as an account of work sponsored by the United States Government. While this document is believed to contain correct information, neither the United States Government nor any agency thereof, nor The Regents of the University of California, nor any of their employees, makes any warranty, express or implied, or assumes any legal responsibility for the accuracy, completeness, or usefulness of any information, apparatus, product, or process disclosed, or represents that its use would not infringe privately owned rights. Reference herein to any specific commercial product, process, or service by its trade name, trademark, manufacturer, or otherwise, does not necessarily constitute or imply its endorsement, recommendation, or favoring by the United States Government or any agency thereof, or The Regents of the University of California. The views and opinions of authors expressed herein do not necessarily state or reflect those of the United States Government or any agency thereof or The Regents of the University of California. 
This page intentionally left blank. 


\section{EXECUTIVE SUMMARY}

\section{Introduction}

This study of the hydrogeology of Chicken Creek Canyon was conducted by the Environmental Restoration Program (ERP) at Lawrence Berkeley National Laboratory (LBNL). This canyon extends downhill from Building 31 at LBNL to Centennial Road below. The leading edge of a groundwater tritium plume at LBNL is located at the top of the canyon. Tritium activities measured in this portion of the plume during this study were approximately 3,000 picocuries/liter ( $\mathrm{pCi} / \mathrm{L}$ ), which is significantly less than the maximum contaminant level (MCL) for drinking water of $20,000 \mathrm{pCi} / \mathrm{L}$ established by the Environmental Protection Agency.

There are three main pathways for tritium migration beyond the Laboratory's boundary: air, surface water and groundwater flow. The purpose of this report is to evaluate the groundwater pathway. Hydrogeologic investigation commenced with review of historical geotechnical reports including 35 bore logs and 27 test pit/trench logs as well as existing ERP information from 9 bore logs. This was followed by field mapping of bedrock outcrops along Chicken Creek as well as bedrock exposures in road cuts on the north and east walls of the canyon. Water levels and tritium activities from 6 wells were also considered. Electrical-resistivity profiles and cone penetration test (CPT) data were collected to investigate the extent of an interpreted alluvial sand encountered in one of the wells drilled in this area. Subsequent logging of 7 additional borings indicated that this sand was actually an unusually well-sorted and typically deeply weathered sandstone of the Orinda Formation. Wells were installed in 6 of the new borings to allow water level measurement and analysis of groundwater tritium activity. A slug test and pumping tests were also performed in the well field.

\section{Geology}

Analysis of the geologic data resulted in delineation of the bedrock structure and the soil deposit geometry and texture in Chicken Creek Canyon. The bedrock structure consists primarily of Orinda Formation sandstones faulted over Great Valley Group shales and sandstones. The dip of strata in both units is moderately $\left(25^{\circ}-40^{\circ}\right)$ to the northeast, with an apparent fold in the Orinda Formation near its fault contact with the Great Valley Group. This fold forms an anticline with a nearly horizontal axis. The southwestern limb dips moderately to the southwest. The Orinda Formation in the center of the upper portion of the canyon is overlain primarily by brecciated and slickensided siltstone. These materials are interpreted as a paleolandside deposit derived from Orinda Formation materials. This deposit likely extends a considerable distance upslope. The bedrock along the axis of the canyon is overlain by up to 70 feet of soil composed primarily of clay. The soil fills a deep incision into the underlying bedrock. 


\section{Hydrology}

Analysis of the geologic and hydrologic data resulted in characterization of the hydrogeology of Chicken Creek Canyon. No permeable pathways consisting of coarse-grained soils were found in the soil deposits, with one exception. This exception is coarse-grained alluvium filling a bedrock incision in the northwestern portion of the canyon. The bedrock incision appears to be a former alignment of Chicken Creek. The alluvial channel fill apparently terminates where Chicken Creek is incised into bedrock. Slug testing of Orinda Formation sandstones and Great Valley Group shales and sandstones such as those in Chicken Creek Canyon indicates that these materials generally have relatively high permeability throughout the LBNL site. The relatively high permeability of Orinda Formation sandstones in Chicken Creek Canyon was confirmed by slug testing. No wells were screened exclusively in the Great Valley Group in the canyon, so slug testing this unit was not possible. Based upon the similarities in lithology and fracturing between the Great Valley Group in the canyon and the rest of LBNL, the presumption is that this unit is relatively permeable in the canyon as well.

The Orinda Formation and the Great Valley Group are separated by a low permeability zone consisting of sheared and unsheared Great Valley Group rock 10's of feet thick at and parallel to the main fault contact. The low permeability of this zone has been characterized by slug tests in wells throughout LBNL. The similarity of this zone as it exists in Chicken Creek Canyon to that elsewhere at LBNL was confirmed by geologic logging in Chicken Creek Canyon. Therefore this zone is presumed to have low permeability in Chicken Creek Canyon as well. Pump testing in the Orinda Formation adjacent to the fault zone confirmed it forms a hydrologic boundary. Pump testing also indicated that the paleolandslide deposit of Orinda siltstone has low permeability. This was further supported by water level responses to discrete precipitation events.

\section{Tritium Transport}

Based upon the hydrogeologic characterization, the groundwater tritium plume appears to be stable. This is due to the lack of permeable pathways either in bedrock or surficial soils downgradient of the existing plume. Analysis of tritium activities in groundwater from all the wells and borings in the canyon, which are or were screened in the Great Valley Group, the Orinda Formation, the paleolandslide debris, and soil deposits, indicates tritiated groundwater occurs only in the coarse-grained alluvial channel fill in the northwestern portion of the canyon and the Orinda Formation sandstones down slope, both of which are located within the Laboratory's boundary.

Results from a surface water sample indicated that tritiated groundwater was seeping to Chicken Creek. The tritium activity in this seepage water $(1,756 \mathrm{pCi} / \mathrm{L})$ was significantly less than the maximum contaminant level (MCL) for drinking water of 20,000 pCi/L, and no tritium was detected in two water samples collected from Chicken Creek downstream of the seep. 


\section{Conclusion}

This study characterized the geology and hydrogeology of Chicken Creek Canyon. Based upon this work, the extent of tritium contamination in groundwater is not expected to expand, and so the tritium groundwater plume is expected to remain within the Laboratory's boundary. 
This page intentionally left blank. 


\subsection{INTRODUCTION}

This document reports on hydrogeologic studies by the Lawrence Berkeley National Laboratory's (LBNL's) Environmental Restoration Program (ERP) in Chicken Creek Canyon. The study area is shown on Figure 1-1. These studies were conducted to evaluate the potential for tritium migration beyond the Laboratory's boundary via groundwater flow. Migration of tritium beyond this boundary via surface water and air flow is discussed in other documents (such as LBNL 2003 for surface water flow and LBNL 2006 for air flow).

The study area consists of the lower portion of the original Chicken Creek Canyon. The upper portion of the canyon was extensively altered by grading for buildings, roads and parking lots at LBNL. For the purpose of this report, the term Chicken Creek Canyon refers to the area from Cyclotron Road on the north to Centennial Drive on the south, and from Chicken Creek on the west to the eastern side of the canyon floor. The upper portion of this area is managed by LBNL and the lower portion by the University of California, Berkeley.

The operation of a former facility at the Lab led to the formation of a tritium plume in the groundwater. The scope of work reported upon in this document was to determine if the hydrogeologic setting in Chicken Creek Canyon was likely to allow tritiated groundwater to migrate off site.

\subsection{BACKGROUND}

Results of more than a decade of study have identified a groundwater tritium plume that extends from the vicinity of Building 75 to the southern areas of Building 31 in the Chicken Creek Canyon. The source of this plume was a tritium labeling facility that was closed in December 2001. The extent of the tritium plume in the 3rd quarter of (federal fiscal) year 2002 is shown on Figure 2-1 (LBNL, 2002). The farthest downgradient monitoring well in which tritium has been detected in groundwater prior to this study was MW31-97-17. The downgradient end of the tritium plume is defined by a consistent lack of tritium detections in groundwater from wells MW31-97-18 and MW31-98-17 at a detection limit of $300 \mathrm{pCi} / \mathrm{L}$. Both of these wells are screened at least in part in saturated, undifferentiated Quaternary soil deposits.

The bedrock beneath the tritium plume consists entirely of the sedimentary Orinda Formation. The Orinda Formation consists of siltstones, sandstones, and lesser amounts of conglomerate within the study area. Sandstones and shales of the Great Valley Group occur just downhill of MW31-97-17. Wherever observed, the contact between these two geologic units is slickensided, brecciated, and contains fault gouge indicating these two units were brought into juxtaposition by faulting. LBNL 2000 reports this fault dips shallowly to moderately $\left(20^{\circ}\right)$ to the northwest, subparallel to the bedding in the Orinda Formation and Great Valley Group. 


\subsection{WORK PERFORMED}

\subsection{Field Mapping}

Bedrock exposures in upper Chicken Creek Canyon were mapped to provide some constraints on the extent of Quaternary soil deposits and to assist in understanding the bedrock structure beneath the canyon. Bedrock exposed in four locations along road cuts were mapped as well as bedrock exposures along Chicken Creek west of Building 31, as shown on Figure 3-1.

\subsection{Bore Log and Test Pit Review}

Geologic data collected from borings and test pits in Chicken Creek Canyon as of November, 2002, were analyzed to determine the extent of the Quaternary soils and the structure of the bedrock. The data were further utilized to determine if extensive coarsegrained deposits within the Quarternary soils existed which might be capable of transmitting water.

Data from 50 borings and 27 test pits, shown on Figures 3-2a, 3-2b, and 3-2c, were examined. A total of 35 borings were previously drilled for geotechnical data collection. These include 32 borings approximately evenly divided among three reports by two consulting firms. One report focused primarily on upper Chicken Creek Canyon (Harza Kaldveer, 1993), another on lower Chicken Creek Canyon (Geomatrix, 1994), and a third on all of Chicken Creek Canyon (Harza, 1995). The other three geotechnical borings were performed under the direction of two other geotechnical consultants (Dames and Moore, 1962a, and Harding, Miller, Lawson and Associates, 1969). The 15 remaining borings were drilled by LBNL's ERP for characterizing the tritium plume and the bedrock structure in the area. These include 7 borings drilled in 2002 as a part of this study. Logs for 21 of the test pits are in the report on lower Chicken Creek Canyon (Geomatrix, 1994). Logs for the other six test pits are in the report on all of Chicken Creek Canyon (Harza, 1995).

Analyzing the extent of coarse-grained deposits in the Quaternary soils in Chicken Creek Canyon as a whole requires consistency between the different data sets with regard to the textural composition. To determine consistency between data sets, logs from borings in different data sets but close spatial proximity were compared. Borings MW31-98-17 and EB-4_352, approximately 15 feet apart, both encountered silty clay below 8 feet below ground surface (bgs) and clay below 15 to 20 feet bgs. Borings MW31-97-18 and EB$2 \_352$, approximately 25 feet apart, both encountered clay below 8 feet bgs and clay with a sand/gravel fraction consisting of sandstone below 25 to 30 feet bgs. These comparisons indicate the Quaternary deposit descriptions in the Harza Kaldveer 1993 logs are sufficiently consistent with the ERP logs to form a joined data set. SB31-97-2 and EB-4_300, approximately 30 feet apart, both encountered clay below 8 feet bgs and sandy clay below 14 to 17 feet bgs. These comparisons indicate the Quaternary deposit descriptions in the Harza, 1995, logs are sufficiently consistent with the ERP logs to form a joined data set. Borings EB-7_352 and 3A_351, which are approximately 50 feet apart, 
both log sandy clay below 7 feet bgs and sandy clay with gravel below 20 to 23 feet bgs. These comparisons indicate that the Quaternary deposit descriptions in the Geomatrix, 1994, logs are sufficiently consistent with the Harza Kaldveer, 1993, logs to form a joined data set.

The borings for Harza Kaldveer in upper Chicken Creek Canyon were typically sampled on 5-foot intervals with a 1.5-foot long, split-spoon type sampler. This yielded sample coverage of the borehole length of approximately 30\% (Harza Kaldveer, 1993). Most of the borings for Geomatrix in lower Chicken Creek Canyon were typically sampled on 5-foot intervals to 15 feet bgs, and on 10-foot intervals to the bottom of the boring with various samplers. This yielded total sample coverage of the borehole length of approximately $20 \%$. Three of the Geomatrix borings, numbers 4A, 5A, and 6A, were nearly continuously sampled (Geomatrix, 1994). The borings for Harza throughout Chicken Creek Canyon were typically sampled on 10-foot intervals with a 1.5-foot long, split-spoon type sampler. This yielded total sample coverage of the borehole length of approximately 15\% (Harza, 1995).

Analysis of the geotechnical data required corrections to the ground surface elevation listed on 16 of the bore logs. More than half of these corrections were to logs from the geotechnical report on lower Chicken Creek Canyon (Geomatrix, 1994). These corrections were based upon a comparison of the boring's position with the surface topography and the corrections ranged from 3 feet to 20 feet. Shallow soils not noted as artificial fill on four of the bore logs from the report on upper Chicken Creek Canyon (Harza Kaldveer, 1993) were assigned to the artificial fill unit based upon the soil description and comparison with other bore logs. Soil on one of the logs from the geotechnical report in lower Chicken Creek Canyon (Geomatrix, 1994) was reassigned to the Great Valley Group based upon the soil description and comparison with another bore $\log$.

Analysis of coarse-grained deposits in the Quaternary soils was restricted to the naturally occurring deposits. Analysis of coarse-grained deposits in artificial fill was not carried out due to the discontinuity, small maximum thickness (approximately 10 feet), and generally unsaturated condition of the artificial fill in the canyon.

\subsection{Electrical Resistivity Lines}

Electrical resistivity surveys were conducted along three lines by Norcal Geophysical Consultants, Inc. on June 12, 2002 (Norcal, 2002). The purpose of this work was to survey the distribution of permeable coarse-grained deposits observed in MW31-97-17. It was believed that these deposits would have a high resistivity contrast with the general fine-grained soils in the area. Figure 3-3 shows the location of the electrical resistivity survey lines along with the initial interpretation of the geologic feature represented by each anomaly. The inverted electrical resistivity sections are shown in Appendix 1. 


\subsection{Cone Penetrometer Testing}

Three possible high electrical resistivity trends were interpreted from the resistivity survey data as shown on Figure 3-4. These trends can correlate with relatively more permeable coarse-grained deposits. Such deposits would have a high contrast in tip resistance and sleeve friction in a cone penetrometer test (CPT) as compared to the prevailing fine-grained soils in the area. Therefore, these trends were investigated with CPTs. CPTs were conducted in the vicinity of MW31-97-17 to discriminate which, if any, of the electrical resistivity anomalies were due to the presence of coarse-grained deposits.

Locations of six CPTs are shown on Figure 3-4. The testing was performed by an M5T ("rhino") rubber-track mounted, limited-access, auger-drilling rig adapted to perform CPTs. The CPTs were conducted on Saturday, August $17^{\text {th }}$. The CPT logs resulting from this campaign are included as Appendix 2.

The CPT holes were left open subsequent to testing to allow for depth-to-water measurements and collection of grab groundwater samples, if possible. Water levels were monitored to equilibrium and then measured. Subsequently, a grab groundwater sample was collected from CPT31-02-4 for tritium analysis, and all the CPT holes were grouted with neat cement.

\subsection{Drilling and Temporary Well Installation}

Subsurface characterization in the vicinity of MW31-97-17 continued on September 18th, November $1^{\text {st }}$, and December $12^{\text {th }}$, 2002. Characterization was continued by hydraulicpercussion driven coring and hollow-stem auger drilling with hydraulic-percussion driven, split-spoon soil sampling performed with the M5T drilling rig. Locations of soil borings SB31-02-1 through -7 are shown on Figure 3-4, and the logs of these borings are included in Appendix 3. Temporary groundwater wells were installed in borings SB3102-1 and -2 , and -4 through -7 to further characterize the hydrogeology and tritium plume in the vicinity of MW31-97-17.

On March 21 ${ }^{\text {st }}, 2003$, temporary wells SB31-03-1 through SB31-03-3 were installed to study shallow groundwater flow in this area. These installations were motivated by the tritium activity in seepage from location B31_SPRING discussed below. The locations of these wells are also shown on Figure 3-2b, and the logs of these wells are included in Appendix 3. Wells casings were installed in 5 to 7.5 -foot deep open borings drilled by hand auger. A thin bentonite surface seal was placed around each well casing. Silty gravel at the base of SB31-03-1 prevented further advance. Gravelly clay was encountered in SB31-03-3.

Temporary groundwater well SB31-03-4 was installed to a depth of 14 feet on May $29^{\text {th }}$, 2003 with a portable, hydraulically powered, solid-stem auger drill rig. This well was screened to a greater depth and had a more extensive seal than adjacent wells SB31-03-1 and -2 . The location of this well is shown on Figure $3-2 b$, and the log is included in Appendix 3. 


\subsection{Drain Outfall, Creek And Seep Sampling}

In winter 2002/2003, Pamela Sihvola, a member of the community group Citizens to Minimize Toxic Waste, noted standing water in a swale between SB31-02-6 and Chicken Creek. She sampled this water and had its tritium activity analyzed. She reported this water contained detectable tritium. This standing water was not observed by ERP personnel during the first phase of this study in summer/fall of 2002, indicating it is a seasonal phenomenon. Subsequently, the ERP sampled water seeping from the base of this swale where it joined Chicken Creek in February, 2003. This sample location is shown on Figure 3-5 as B31_SPRING. A tritium activity of $1,756 \mathrm{pCi} / \mathrm{L}$ was detected in this water. The flow from this seep was considerably less than the flow in Chicken Creek.

In February, 2003, storm drain outfall and creek sampling was carried out to determine the distribution of tritium in surface waters. As shown on Figure 3-5, three pipes discharge to the head of Chicken Creek. These pipes are a 12-inch diameter corrugated metal storm drain, a subdrain, and a 16-inch diameter corrugated metal storm drain. Of these pipes, almost the entire flow at the time of sampling was from the 12-inch diameter storm drain with a minor contribution from the subdrain. No flow was observed from the 16-inch diameter storm drain. A surface water sample was collected from Chicken Creek at location SD31-03-1. The creek at this location was comprised of the combined flow from the 12-inch diameter storm drain and the subdrain. The tritium activity in this sample was $674 \mathrm{pCi} / \mathrm{L}$.

At the time of sampling, additional flow entered Chicken Creek from a 24-inch diameter corrugated plastic storm drain below SD31-03-1 as shown on Figure 3-5. The flow from this pipe was significantly larger than the flow in Chicken Creek above this outfall. No detectable tritium $(<300 \mathrm{pCi} / \mathrm{L})$ was observed in a sample collected from the outfall of this pipe (SD31-03-2).

A surface water sample was collected from Chicken Creek at location CC_FALLS2 downstream of SD31-03-1 and SD31-03-2 as shown on Figure 3-5. The purpose of this sample was to determine the tritium activity in the composite water from the three flowing pipes. No detectable tritium $(<300 \mathrm{pCi} / \mathrm{L})$ was observed in this sample.

A surface water sample was collected from Chicken Creek at location CC_POOL4 downstream of B31_SPRING as shown on Figure 3-5. The purpose of this sample was to determine the effect of groundwater seepage to the creek from B31_SPRING on the tritium activity in the creek. No detectable tritium $(<300 \mathrm{pCi} / \mathrm{L})$ was observed.

A surface water sample was collected from Chicken Creek at location CC_POOL5 as shown on Figure 3-5. The purpose of this sample was to determine tritium activity in the creek downstream from the tritium groundwater plume. No detectable tritium $(<300$ $\mathrm{pCi} / \mathrm{L}$ ) was observed. 


\subsection{Slug and Pumping Tests}

A slug test was performed in MW31-97-17 by the addition of a specified volume of water. Subsequent water level measurements were collected from a pressure transducer via a data logger. However, the water level increase due to the slug of water added dissipated so rapidly that there were insufficient data to determine hydraulic conductivity.

A pumping test was conducted on October 21, 2002. A total volume of 290 gallons was extracted from MW31-97-17 at a rate of approximately 0.5 gallons per minute (gpm) for the first 49 minutes and approximately $1.1 \mathrm{gpm}$ for the following 252 minutes. The drawdowns at the end of the test are shown on Figure 3-6.

Another pumping test was conducted on October 29, 2002. A total of 353 gallons of water was pumped from MW31-97-17 at a rate of approximately $1.1 \mathrm{gpm}$ for the first approximately 280 minutes, pumping was stopped for the subsequent 110 minutes, and pumping continued at a rate of approximately $1 \mathrm{gpm}$ for the following 54 minutes.

\subsection{RESULTS}

\subsection{Undivided Quaternary Soil Distribution}

Based upon the CPT results along with the soil types and lithologies encountered during drilling and sampling, the identified electrical resistivity trends did not appear to correlate to any significantly more permeable structures within the soil deposits in the vicinity of MW3197-17. To further determine the prevalence of relatively more permeable pathways within the natural soil deposits in Chicken Creek Canyon, the data collected for this report were analyzed in concert with the preexisting geotechnical data set.

The natural soil deposits are greater than 70 feet thick along the axis of the canyon, as shown on Figures 4-1a and 4-1b. These deposits reside in a deep incision into the bedrock as shown on Figures 4-2a and 4-2b. The shape of the soil deposits, as shown on the two preceding figures, indicates the total width of the deposit has been explored in the upper canyon, whereas only the eastern half of the deposit has been explored in the lower canyon.

Despite the thickness of the natural soils in Chicken Creek Canyon, clean coarse-grained soils were described only in boring 6A_351 near the bottom of lower Chicken Creek Canyon as shown on Figure 4-3. Several beds of probably saturated, clean, medium-grained or coarser sand were encountered in the boring. These beds range in thickness from a couple of inches to perhaps a foot. Boring 6A_351 is one of only three near-continuously sampled borings logged by geotechnical consultants in Chicken Creek Canyon. The detection of numerous sections of sand ranging from 0.04 to 1 foot thick in boring 6A_351 could be due entirely or in part to the near-continuous sampling performed in this boring, as compared to the vast majority of the other geotechnical borings in Chicken Creek Canyon. However, another near-continuously sampled boring, 5A_351, which is approximately 100 feet up canyon from boring 6A_351, does not record any clean coarse-grained soils, and only one coarse-grained soil at all, a clayey sand. These borings were logged by the same individual. 
Therefore, the sand beds in boring 6A_351 do not appear to extend significantly up canyon, strongly suggesting they do not intersect tritiated groundwater.

Twelve borings in Chicken Creek Canyon encountered clayey or silty coarse-grained soils as shown on Figure 4-3. These soils were encountered near the top and the bottom of Chicken Creek Canyon. These soils were not encountered in the middle portion of Chicken Creek Canyon. Although the boring density is lower in the middle portion of the canyon, the lack of coarse-grained soil encounters in this area is not simply an artifact of sampling density. In the upper and lower portions of the canyon, these soils occurred in more than $50 \%$ of the borings. There are approximately nine borings in the middle portion of the canyon. Therefore, the clayey or silty coarse-grained soils in the upper portion of the canyon do not appear to be connected to clayey or silty coarse-grained soils in the lower portion of the canyon. Further, with the exception of borings SB31-03-1 and -3 , which are discussed below, there are no apparent correlations between the coarsegrained soils described on the bore logs based upon either material descriptions or depth.

The bore logs in this report provide further evidence that the coarse-grained soils in Chicken Creek Canyon are not significantly transmissive. All of the coarse-grained soils described on these bore logs, except those of SB31-03-1 and SB31-03-3, classify these soils using a non-USCS soil classification, such as "SM/ML." A coarse-grained classification followed by a slash and then a fine-grained classification is an informal designation used to indicate that the coarse grains in the soil are supported by the finegrained soil (an arrangement sometimes referred to as "matrix-supported"). Therefore the permeability of the soil is completely dominated by the fine-grained soil. This nonUSCS classification is used to overcome a limitation of the USCS, which divides coarsegrained from fine-grained soils based upon a $50 \%$ by weight criterion, whereas the hydrologic and engineering behavior of a soil is primarily controlled by whether or not the coarse-grained soil pores are completely filled by fine-grained soil, which typically occurs at and above a fine-grained soil proportion of $20 \%$ to $30 \%$ by weight.

Boring SB31-03-1 and SB31-03-4 encountered silty gravel with a USCS classification of GM 6.5 to 7.5 feet below the ground surface, as shown on Figure 4-3. Boring SB31-03-3 encountered clayey gravel with a USCS classification of GC two feet below the ground surface. These gravels occupy an incision into the bedrock surface shown on Figure 42b. This incision was likely eroded by a former alignment of Chicken Creek, and the soil texture of the deposits encountered in this incision is consistent with the alluvium in the current alignment of Chicken Creek. Therefore these gravel deposits are interpreted as alluvium. Groundwater rapidly seeped from this alluvium into all three borings. Tritium activities in groundwater from these wells were intermediate between those at MW77-9711 and MW31-97-17, as discussed below. 


\subsection{Bedrock in Chicken Creek Canyon}

Both the Great Valley Group and the Orinda Formation underlie Chicken Creek Canyon. The structure and lithology of both these units in the study area is described below.

\section{Great Valley Group}

Considering the attitudes measured in this study as well as reported by LBNL 2000, Great Valley Group strata dip moderately $\left(25^{\circ}\right.$ to $\left.45^{\circ}\right)$ to the northeast along the east side of the canyon where they crop out. The Great Valley Group underlying the upper portion of Chicken Creek Canyon consists of sandstone, siltstone, and shale as described on the bore logs. The Great Valley Group underlying the middle and lower portions of the canyon (down section) consists predominantly of shale as described on the bore logs.

\section{Great Valley Group/Orinda Formation Fault Contact}

The contact between the Great Valley Group and the Orinda Formation has been previously described and mapped as an inactive fault striking north $65^{\circ}$ west and dipping $20^{\circ}$ northeast (LBNL 2000). The contact could not be directly observed in any bedrock exposure within the canyon. Borings drilled by the ERP have allowed the subcrop of the contact to be mapped, as shown on Figure 4-4. The subcrop pattern across the canyon indicates the strike of the fault in this area is north $80^{\circ}$ west, which is more westerly than observed to the west.

Wells MW31-97-17 and SB31-02-5 traverse the fault as shown on cross section A-A' on Figure 4-5. The location of this cross section is shown on Figure 4-4. In both of these borings the Orinda Formation adjacent to the contact consists of a couple of feet of bluish gray, closely fractured sandstone. The Great Valley Group consists of dark gray to black, crushed to intensely fractured, brecciated, slickensided, fine-grained fault gouge. The apparent fault dip between MW31-97-17 and SB31-02-5 is $11^{\circ}$, which equates to a true dip of $16^{\circ}$ given a strike of north $80^{\circ}$ west. This compares well with the dip previously reported (LBNL 2000).

Great Valley Group rocks in the vicinity of the fault contact, as encountered in borings MW31-97-17, MW31-97-18, SB31-97-2, and SB31-02-5, consist predominantly of dark gray to black, fine-grained rock sheared to fault gouge. Brecciation and slickensides are described in the fine-grained rocks of the Great Valley Group in SB31-97-3 as well, while the coarse-grained rocks in this boring are not described as brecciated or slickensided. The base of the sheared, fine-grained rocks in SB31-97-3 is a distance of 95 feet perpendicular to the fault contact with the Orinda Formation. This is the maximum distance explored by the ERP away from the fault contact. Shear features were not noted on any of the geotechnical logs, with the exception of those from Dames and Moore, 1962a, even though some of the geotechnical borings encountered finegrained Great Valley Group rocks near the fault, such as EB-2_300. This contrast 
between the ERP bore logs and the geotechnical bore logs suggests that shear features were simply not generally described, rather than not being encountered, in the latter.

\section{Orinda Formation}

The Orinda Formation underlying upper Chicken Creek Canyon consists of two distinct stratigraphic assemblages: one coarse-grained and one fine-grained and sheared in places, as shown on Figure 4-4. The coarse-grained assemblage (To on Figure 4-4) underlies the western and southeastern portions of upper Chicken Creek Canyon, while the finegrained, sheared assemblage (QTls(o) on Figure 4-4) underlies Chicken Creek Canyon to the east and northeast. The coarse-grained assemblage consists predominantly of fine and medium-grained sandstone that is brown where deeply weathered and gray where little weathered. Moderate weathering extends 10 to 20 feet into this material from the top of bedrock.

The Orinda Formation exposed along Cyclotron Road and in MW77-97-11 consists entirely of fine- and medium-grained sandstone. Almost half of the Orinda Formation strata in MWP-9 consist of sandstone with the remainder consisting predominantly of siltstone. This well also encountered conglomerate, within which it is screened. The dip measured in the sandstone exposure along Cyclotron Road is moderately $\left(33^{\circ}\right)$ to the northeast, as is typical in the Orinda Formation at LBNL.

In the vicinity of Chicken Creek, the coarse-grained assemblage of the Orinda Formation consists almost exclusively of sandstone, and where deeply weathered in this area typically exhibits orange-brown staining along fractures. The Orinda Formation near the fault contact with the Great Valley Group, as exposed in Chicken Creek, is dipping moderately $\left(30^{\circ}\right)$ south to southwest. This reversal of dip direction in the Orinda Formation near the contact with the Great Valley Group has been observed in other areas of LBNL (LBNL 2000).

These dips suggest the strata in the coarse-grained assemblage form an anticline near the contact with the Great Valley Group. Dips in cores from SB31-02-6 are horizontal to shallow $\left(0^{\circ}\right.$ to $\left.10^{\circ}\right)$ dipping suggesting the axis of the anticline is in the vicinity of this boring. This anticline is shown on cross section B-B' (Figure 4-6). The location of this cross section is shown on Figure 4-4. The strike of bedding in the fold's limbs indicates the trend of the anticline's axis is subparallel to the strike of the fault contact between the Orinda Formation and Great Valley Group, and the plunge of the anticline's axis is nearly horizontal. This anticline may be due to folding of the Orinda Formation strata as they were faulted over the Great Valley Group. The Orinda Formation does not exhibit shear features near the fault contact with the Great Valley Group. This is typical for the Orinda Formation throughout LBNL as encountered near this contact in the Old Town and Bevalac areas (LBNL 2000).

The fine-grained assemblage of the Orinda Formation underlying the upper portion of Chicken Creek Canyon consists predominantly of siltstone. Three sets of borings encountered the Orinda Formation in this area: borings reported in Dames and Moore, 1962a, ERP borings from 1991 to 2002, and borings reported in Harza Kaldveer, 1993. The 
siltstone in this area is generally described as brown in the shallower subsurface, presumably where it is weathered, and medium gray, gray, olive gray, and gray blue deeper, where it is presumably unweathered. Lesser amounts of claystone and shale, typically red or reddish brown and gray or olive gray, are noted. Finally, small amounts of sandstone are described as gray, olive gray, and blue gray.

The ERP and Dames and Moore, 1962a, bore logs note that some of the Orinda Formation rocks underlying this portion of Chicken Creek Canyon are brecciated, slickensided, and/or "sheared." The rock fabric in the upper 7 feet of the Orinda Formation (based upon grain size and color) in SB31-02-1 and -2 is apparently so disrupted that these materials are described as soils. The Harza Kaldveer, 1993, bore logs in this area do not note any of these features. However, as previously discussed, logs from this set do not note these features at the Great Valley Group/Orinda Formation contact either, indicating shear features were not described on these logs in general.

Based upon the contrast in lithology in the Orinda Formation underlying Chicken Creek Canyon, and the shear features noted in the rocks underlying the eastern and northeastern portions of the canyon, the rocks in this area are interpreted as paleolandslide debris. This is consistent with shear features noted up canyon in the excavation for Building 77 (Dames and Moore 1962b) and in numerous borings (Holland and Wollenberg 1992), as well as the original geomorphology of the canyon in the vicinity of the Grizzly Gate and Building 77 (Hammon, Jensen \& Wallen 1956 and Anderson, Hyde and Anderson, Jr. 1962).

\subsection{Hydrogeology}

The base of the natural soil deposits is saturated down canyon from the vicinity of MW31-97-17, as indicated by the water levels in MW31-97-18 and MW31-98-17. The lack of any continuous, coarse-grained deposits in the natural soil deposits, with the one exception in the extreme northwestern portion of the study area, described above, indicates that groundwater flow in these deposits occurs primarily through fine-grained soils. Slug testing of wells screened in natural soil deposits at LBNL indicates their hydraulic conductivity ranges from $10^{-6}$ to $10^{-10} \mathrm{~m} / \mathrm{s}$ (LBNL 2000). One of the wells included in this data set is MW31-98-17 at the LBNL boundary in Chicken Creek Canyon. The hydraulic conductivity in this well, as measured by slug testing, is $5 \times 10^{-10}$ $\mathrm{m} / \mathrm{s}$. Based upon these values it is reasonable to conclude that even if the hydraulic gradient is very high, groundwater is flowing slowly through the Quaternary soils. Therefore these soils do not allow significant contaminant migration, except for the posited channel fill encountered in SB31-03-1, -3, and -4.

The conductivity of Great Valley Group rocks as measured by slug tests ranges from $10^{-8}$ to $10^{-4} \mathrm{~m} / \mathrm{s}$ (LBNL 2000). Figure 4-7 indicates the hydraulic conductivity in unsheared Great Valley Group rocks is approximately $10^{-5} \mathrm{~m} / \mathrm{s}$. Figure $4-7$ shows that the hydraulic conductivity in the Great Valley Group decreases within 100 feet of the fault contact with the Orinda Formation. This correlates well with the maximum distance away from the fault that shear features were observed in the Great Valley Group in Chicken Creek Canyon. Figure 4- 
7 indicates the Great Valley Group probably has a hydraulic conductivity of $10^{-8}$ to $10^{-9}$ $\mathrm{m} / \mathrm{s}$ over a thickness of perhaps 25 feet parallel to the fault.

The conductivity of fine-grained Orinda Formation materials (defined as fine-grained sandstone and finer), such as comprise most of the paleolandslide deposit as encountered at SB31-02-1 and SB31-02-2, ranges from $10^{-9}$ to $10^{-6} \mathrm{~m} / \mathrm{s}$ (LBNL 2000). The conductivity of coarse-grained Orinda Formation rocks (defined as coarser than fine-grained sandstone without any silt), such as that in the vicinity of MW31-97-17, ranges from $10^{-7}$ to $10^{-4} \mathrm{~m} / \mathrm{s}$ (LBNL 2000). The rapid water level decrease during the slug test of MW31-97-17 suggests the conductivity at this well is high. The smaller groundwater gradient in the vicinity of this well as compared to up canyon, shown on Figure 4-8, also suggests relatively higher conductivity in this area. Unfortunately, definitive quantitative conclusions from the pumping tests could not be reached for several reasons. The tests were of insufficient duration, unplanned pump rate changes occurred during both tests, and too few water level measurements were collected.

Despite these limitations, the final drawdowns from the October 21, 2002 pumping test qualitatively indicate relatively higher conductivity in the Orinda sandstones in the vicinity of MW31-97-17. The drawdown at CPT31-02-4 to the southwest was 54\% of the pumping well drawdown (not accounting for pumping well efficiency). The drawdown at SB31-02-4, approximately the same distance to the northwest, was $10 \%$ of the pumping well drawdown. The drawdown at CPT31-02-3, halfway between MW3197-17 and SB31-02-4, was 19\% of the pumping well drawdown. All these sites were open to Orinda sandstone similar to that at MW31-97-17. The difference in drawdown matches the configuration of this sandstone, which pinches out not far south of CPT3102-4 but thickens toward SB31-02-4.

Drawdowns in SB31-02-1 northeast of MW31-97-17 were only 6\% of the pumping well drawdown, despite closer proximity to the pumping well than either CPT31-02-4 or SB31-02-4, which had drawdowns of 54\% and $19 \%$ of the pumping well drawdown, respectively, as mentioned. This indicates lower permeability at this well or between it and the pumping well. No drawdown was observed in SB31-02-2 further to the northeast, despite being only about one quarter further away from the pumping well than CPT31-02-4. These results are consistent with the interpretation of the relatively lower permeability of the paleolandslide deposit.

No drawdown was observed in MW31-97-18 to the southeast of MW31-97-17 during either pump test, indicating a lack of hydraulic connection between these two wells. These results are consistent with the interpretation of the relatively lower permeability of the soil deposits and sheared Great Valley Group rocks.

The water table in the upper portion of Chicken Creek Canyon in April, 2003, is shown on Figure 4-8. The water levels along Cyclotron Road suggest that groundwater flows into Chicken Creek Canyon primarily from the northwest. This is plausible as the coarsegrained, shallow Orinda bedrock in this area would facilitate recharge from precipitation due to its higher permeability as compared to the thick fill and colluvial cover to the northeast. 
Chicken Creek flows perennially, as indicated by year-round surface water sampling from two locations on the creek in the study area (LBNL 2003). The isopotentials on Figure 4-8 indicate Chicken Creek is a discharge line in the northwestern portion of the canyon, at least during the later winter and early spring months. The potential in the fluvial deposit at SB31-02-3, SB31-03-2 and SB31-03-3 is higher than in the underlying Orinda Formation as shown on Figures 4-9 and 4-10. This is consistent with the supposition of a relatively high permeability fluvial gravel deposit embedded in lower permeability materials and transmitting water from upgradient.

The edge of the paleolandslide deposit of fine-grained Orinda Formation rocks appears to be discharging water out of the basal shear zone as indicated by the water levels around SB31-02-2 on Figures 4-5 and 4-8. This is consistent with the relatively higher groundwater potentials observed in the basal shear zone of this landslide deposit up canyon (Dames and Moore 1962b) as well in other basal shear zones at LBNL (LBNL 2000).

The relatively lower hydraulic gradient around MW31-97-17 is believed to be due to higher permeability in the Orinda Formation rocks in this area relative to the surrounding hydrogeologic units. Water level measurements in the area around MW31-97-17 before and after precipitation in early November, 2002, indicate that water levels in this area started to respond within about 12 hours of the first precipitation as shown on Figure 411. Precipitation totaled approximately three inches for this storm event which started at 12:30 am on November $7^{\text {th }}$ and ended at 9:30 am on November 8 th. Precipitation occurred during three periods within this time. The first period was from 12:30 am to 8:00 am on November $7^{\text {th }}$ during which slightly over one inch of precipitation occurred. Water levels increased at least nine inches in some wells within a maximum of 34 hours after the start of precipitation and started to decrease again within no more than five, and probably as little as three, days, as shown on Figure 4-11.

The time from first precipitation to first water level response indicates a ground surface to water table hydraulic conductivity greater than $10^{-5} \mathrm{~m} / \mathrm{s}$ assuming uniform $25 \%$ porosity and unit hydraulic gradient. These results are somewhat surprising as the conductivity of the surficial soil cover should be near its annual low associated with the annual low moisture content. This low moisture content was indicated by wide dessication cracks observed in the soil prior to the storm. These cracks may have allowed the infiltrating precipitation to bypass the soil column to some extent and directly enter the underlying bedrock.

As shown on Figure 4-11, the peak response to precipitation was the most delayed at SB31-02-1. The peak response was the smallest at SB31-02-2. These results confirm the pump test result that the permeability at these wells is lower than at the wells to the southwest and west. 


\subsection{Tritium Distribution}

Figure 4-12 shows the tritium activities in upper Chicken Creek Canyon in August, 2003. Tritium activities in MW31-97-17 have been relatively constant or slightly increasing since the well was installed, as shown on Figure 4-13. The tritium activities in groundwater from SB31-02-4 and -5 are typically 1,000 pCi/L higher than in MW31-9717. All of these wells are screened in the same weathered Orinda Formation sandstone. The tritium activity in groundwater from SB31-02-6, screened in the same, however unweathered, Orinda Formation sandstone, is below the detection limit. The tritium activities in groundwater from SB31-02-2 and MWP-9, screened in Orinda Formationderived paleolandslide debris, are below the detection limit. The tritium activity in SB31-02-1, also screened within Orinda Formation-derived paleolandslide debris, is significantly lower than in nearby MW31-97-17 and SB31-02-4.

In the vicinity of Buildings 69/75 and 77 upgradient of the study area, tritiated groundwater is apparently limited to the Quaternary soils (LBNL 2000). The presence of tritiated groundwater in the Orinda Formation in MW31-97-17 indicates that this groundwater migrates into the Orinda Formation as it moves downgradient into Chicken Creek Canyon. Previously, tritiated groundwater at MW77-97-11 was presumed to be entering the well from the Quaternary soils also. However, as shown on Figure 4-14, the water level in this well is consistently below the top of the Orinda Formation, indicating the groundwater in this well is derived exclusively from the Orinda Formation. In contrast, tritium is not detected in groundwater from MWP-9 even though it is screened in coarse-grained Orinda Formation strata similar to MW77-97-11. This is perhaps due to the gradient from MWP-9 to MW77-97-11.

Groundwater samples from SB31-97-3 and MW31-98-17, shown on Figure 4-4 approximately 110 and 240 feet south of SB31-02-5, respectively, have been analyzed for tritium. Tritium was not detected in the single sample from temporary well SB31-97-3, and has not been detected in the regularly collected samples from monitoring well MW31-98-17 (detection limits were typically 300 pCi/L for these analyses). SB31-97-3, which has been abandoned, was screened in the soil deposits and the Great Valley Group and MW31-98-17 is screened in the soil deposits.

\subsection{CONCEPTUAL MODEL}

A conceptual model of the groundwater flow in the vicinity of the tritium plume in upper Chicken Creek Canyon is shown on Figure 5-1. In this model, tritiated groundwater arrives in the Orinda Formation at MW77-97-11 from the upgradient portion of the plume. From this well, the tritiated groundwater flows south, rather than southeast along the gradient, due to the paleolandslide deposit margin to the east, which is a flow barrier. Tritiated groundwater flows from MW77-97-11 into the fluvial deposit intersected by SB31-03-1, SB31-03-3 and SB31-03-4. This flow may be abetted by hydraulic conductivity anisotropy in the north-dipping strata in the Orinda Formation at this location. 
The tritiated groundwater flows downhill through the alluvial deposit. Across the crest of the anticline, there is a strong vertical downward gradient from the alluvial deposit into the Orinda Formation. However, the lack of detectable tritium in groundwater at SB3102-6 despite activities many times the detection limit in groundwater from SB31-03-3 indicates the tritium in the groundwater in the fluvial deposits decays before reaching the depth of SB31-02-6 in the Orinda Formation. This is perhaps due to the hydraulic conductivity anisotropy of the nearly flat-lying Orinda strata at this location, as noted on the log for SB31-03-6.

Downgradient of SB31-03-3, the tritiated groundwater in the fluvial deposit flows more rapidly down into the Orinda Formation. This is due to the higher permeability of the Orinda Formation in this area as compared to upgradient areas, but also may be due to the south-dipping hydraulic conductivity anistropy as shown on Figure 5-2. The portion of the tritiated groundwater in the fluvial deposit which does not flow into the Orinda Formation seeps out at the termination of these deposits in the left bank of Chicken Creek. This seepage may be seasonal, as suggested by the drying out of SB31-03-3 on Figure 4-9.

The tritiated groundwater flowing into the Orinda Formation from the fluvial deposit spreads throughout the permeable Orinda Formation intersected by MW31-97-17, SB3103-4 and SB31-03-5. Seepage of tritiated groundwater to Chicken Creek from this hydrogeologic unit may be occurring in the vicinity of SB31-02-5. The groundwater gradient is large and directed toward the creek, and Orinda Formation outcrops in the creek bank to the southwest of this well. If such seepage is occurring, however, it did not cause detectable concentrations of tritium in the creek during the surface water sampling for this study.

Flow of tritiated groundwater into the toe of the paleolandslide deposit is retarded by its relatively lower permeability. This flow is also prevented by relatively higher groundwater potentials within the shear zone at the base of the deposit as indicated by the potential at SB31-03-2.

\subsection{CONCLUSIONS}

The scope of work for this report was to determine if the hydrogeologic setting in Chicken Creek Canyon was likely to allow migration of tritiated groundwater significantly further down canyon. The investigation in this report indicates that hydrogeologic pathways for further migration of tritium down the canyon via groundwater flow probably do not exist, and therefore the tritium groundwater plume is unlikely to expand downgradient. On this basis, the plume is anticipated to stay well within LBNL's boundaries. 


\section{REFERENCES}

Anderson, Hyde and Anderson, Jr., 1962. Site Grading Plan, Building No. 77, Mechanical Shops, Lawrence Radiation Laboratory. LBNL Drawing Number 5N77C018, scale 1:48.

Dames and Moore, 1962a. Foundation Investigation, Proposed Mechanical Shops, Building 77, Lawrence Radiation Laboratory, Berkeley, California for the University of California. LBNL Geotechnical File 171.

Dames and Moore, 1962b. Engineering Geology of the Lawrence Radiation Laboratory Area, Berkeley, California for the University of California. LBNL Geotechnical File Number 277.

Geomatrix, 1994. Geotechnical Study for the Environmental Health and Safety Building, Strawberry Canyon Facility, Berkeley, California. LBNL Geotechnical File Number 351.

Gregg In Situ, Inc., 2002, Presentation of Cone Penetration Test Data, UCLBNL, CPT Subsurface Investigation, Berkeley, California, August, 2002, dated August 21, 2002.

Hammon, Jensen \& Wallen, 1956. Topographic Map - Plot 'O' of 'M' Peralta Grant, LBL Drawing Number B21G0336, scale 1:2400.

Harding, Miller, Lawson and Associates, 1969. Bore logs for Job 2000.64. LBNL Bore Log File Number 30.

Harza Kaldveer, 1993. Geotechnical Investigation for Proposed Chicken Creek Parking Area, Lawrence Berkeley National Laboratory, Berkeley, California. LBNL Geotechnical File Number 300.

Harza, 1995. Geotechnical Feasibility Study for Chicken Creek Study Area in Oakland, California. LBNL Geotechnical File Number 352.

Holland, P.J. and H.A. Wollenburg, 1992. Initial Appraisal of the Geologic Controls of Groundwater Occurrence and Movement in the "Grizzly" Area of Lawrence Berkeley Laboratory. LBID-1852.

LBNL, 2000. Draft Final RCRA Facility Investigation Report, Environmental Restoration Program, Lawrence Berkeley National Laboratory, Berkeley, California, September 2000.

LBNL, 2002. Environmental Restoration Program Quarterly Progress Report, Third Quarter Fiscal Year 2002 (April 1 to June 30, 2002).

LBNL, 2003. Summary of Radionuclide Investigations for Lawrence Berkeley National Laboratory, Environmental Restoration Program, September 2003. 
LBNL, 2006. Site Environmental Report for 2005, Environmental Health and Safety Division, July 2006. LBL-27170.

Norcal Geophysical Consultants, Inc., 2002. Electrical Resistivity Survey, Chicken Creek Area, Lawrence Berkeley National Laboratory, dated July 7, 2002. 


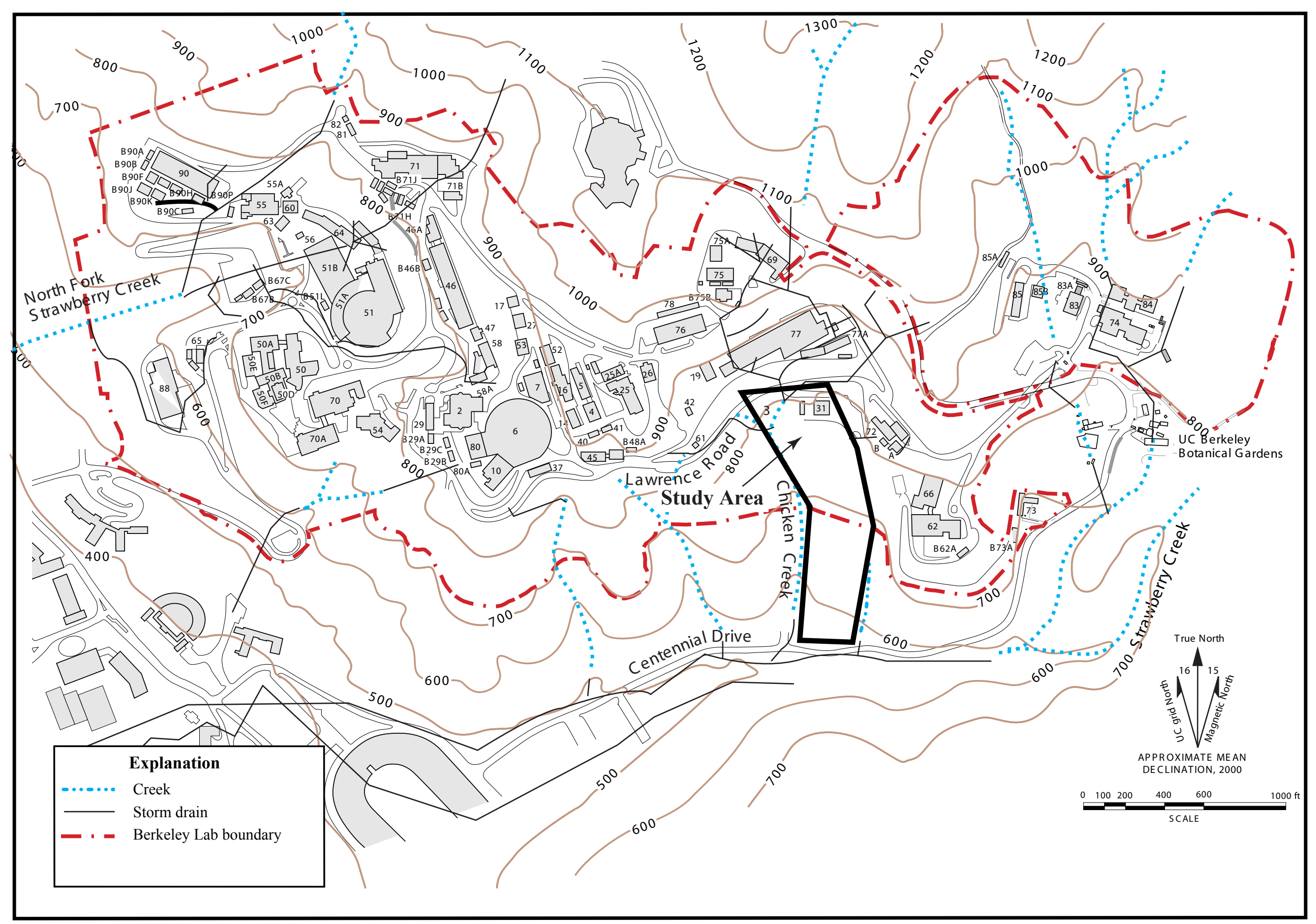

Figure 1-1. Location of study area. 


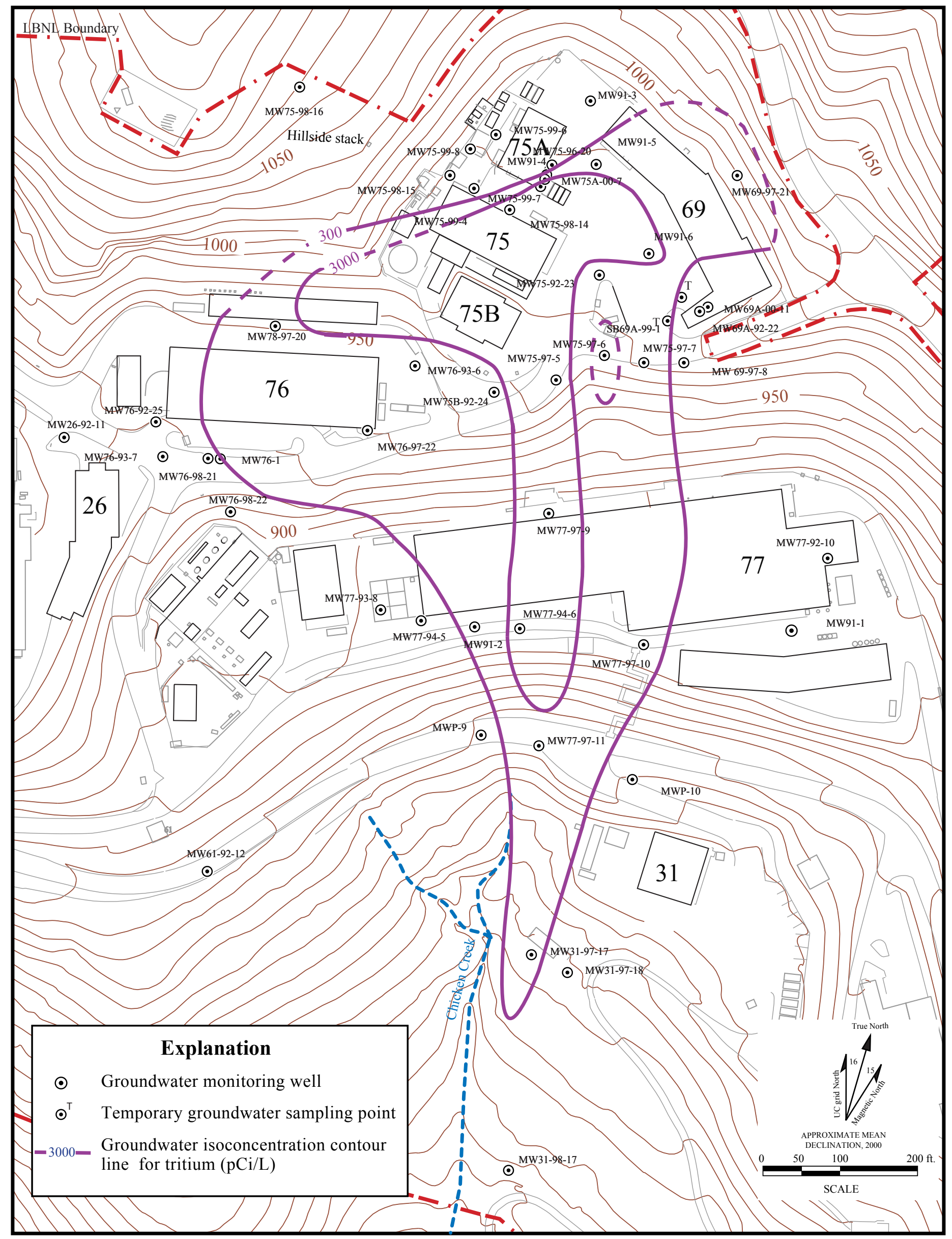

Figure 2-1. Location of the tritium plume based upon 3rd quarter, 2002 results (LBNL 2002). 


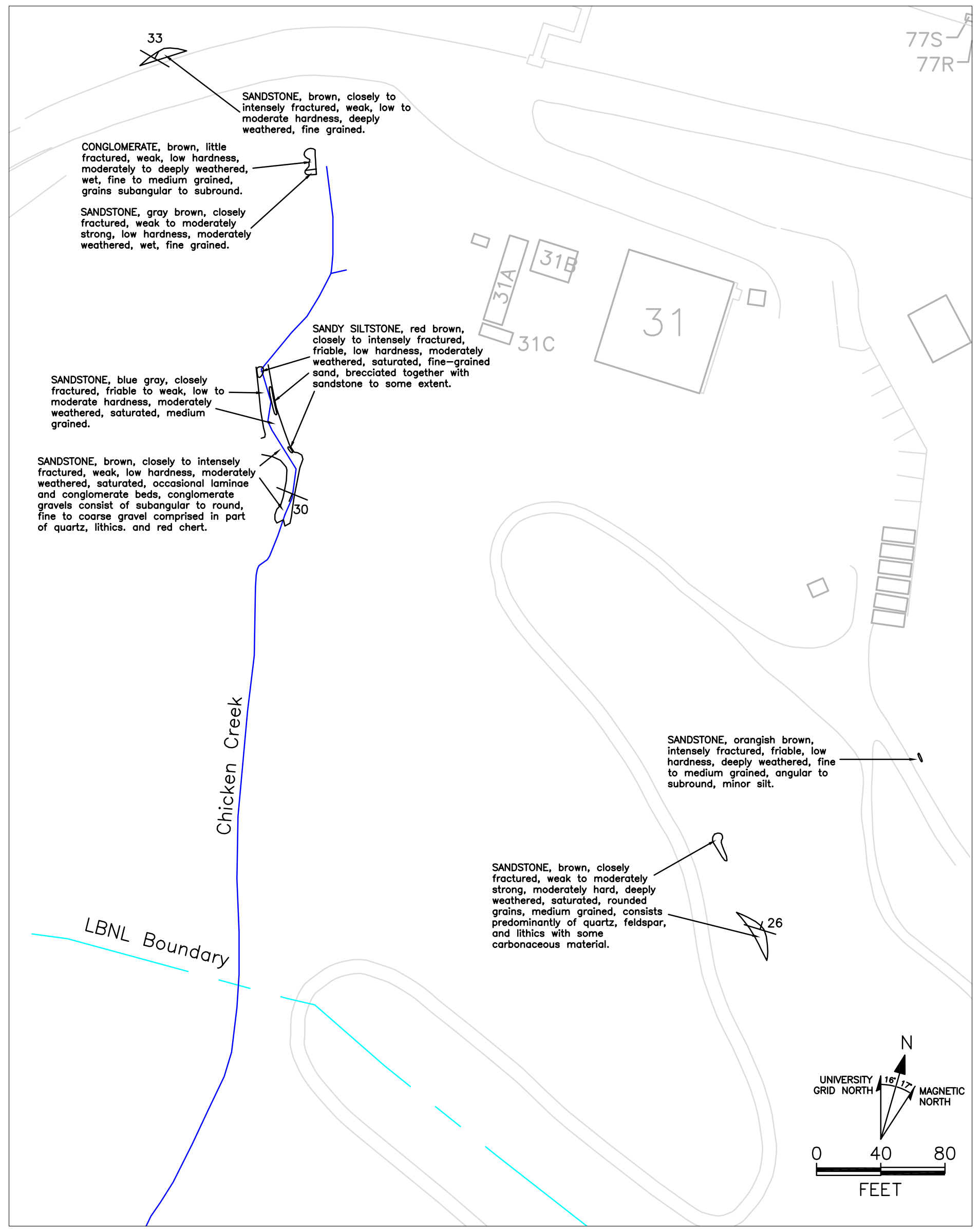

Figure 3-1. Map of bedrock exposures in upper Chicken Creek canyon. 


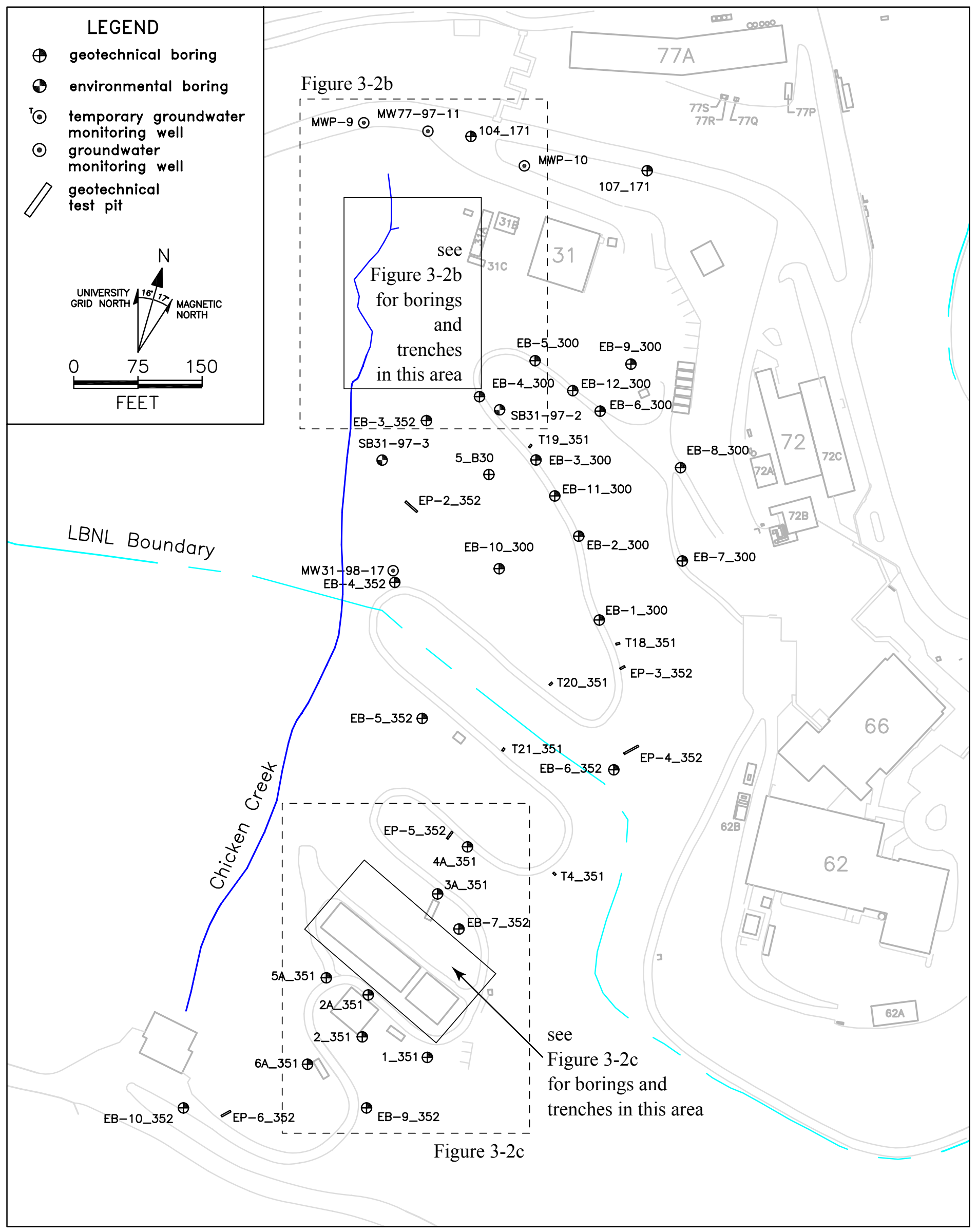

Figure 3-2a. Borings and test pits in Chicken Creek canyon. 


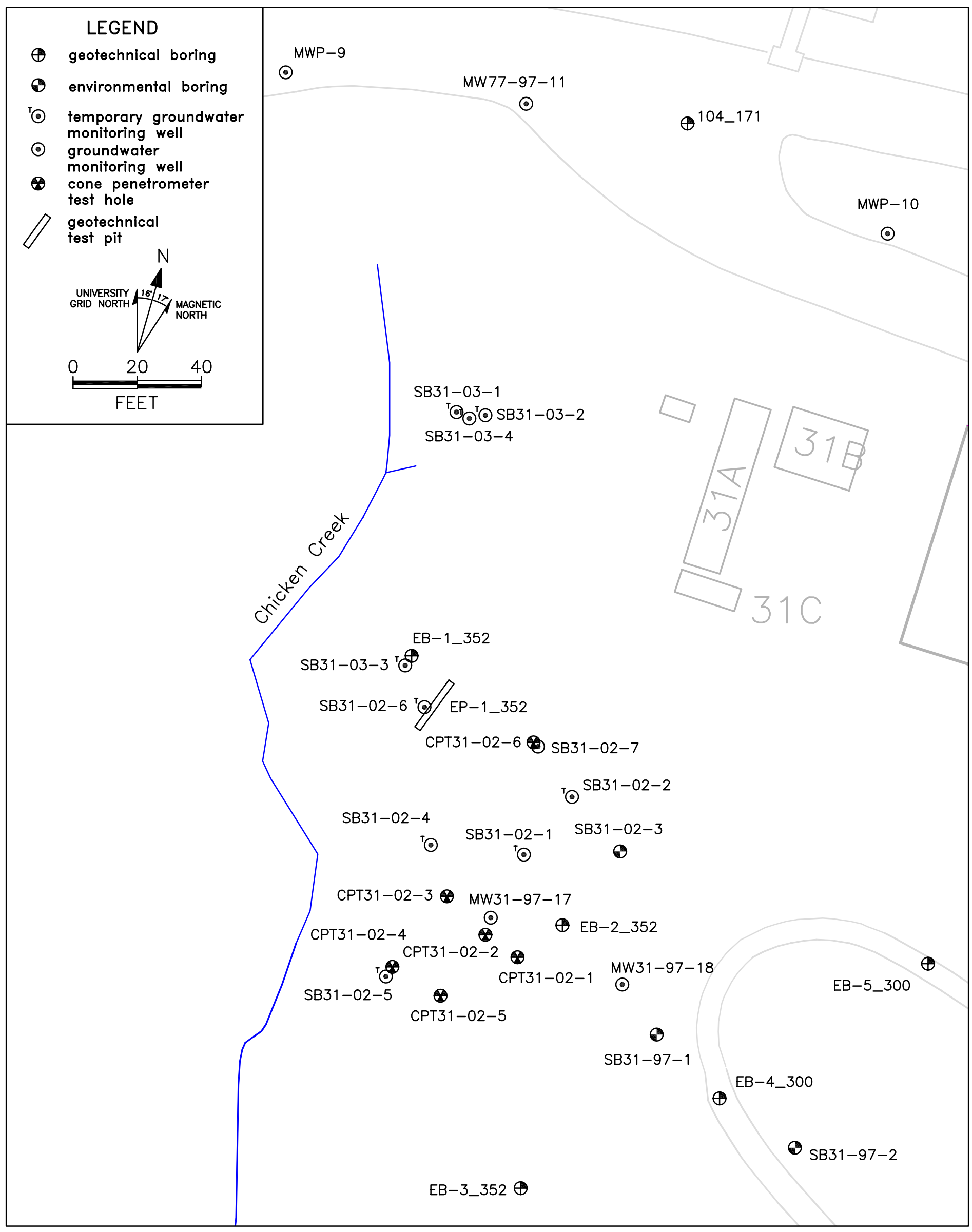

Figure 3-2b. Borings, test pits, and cone penetrometer tests in the northwestern portion of upper Chicken Creek canyon. 


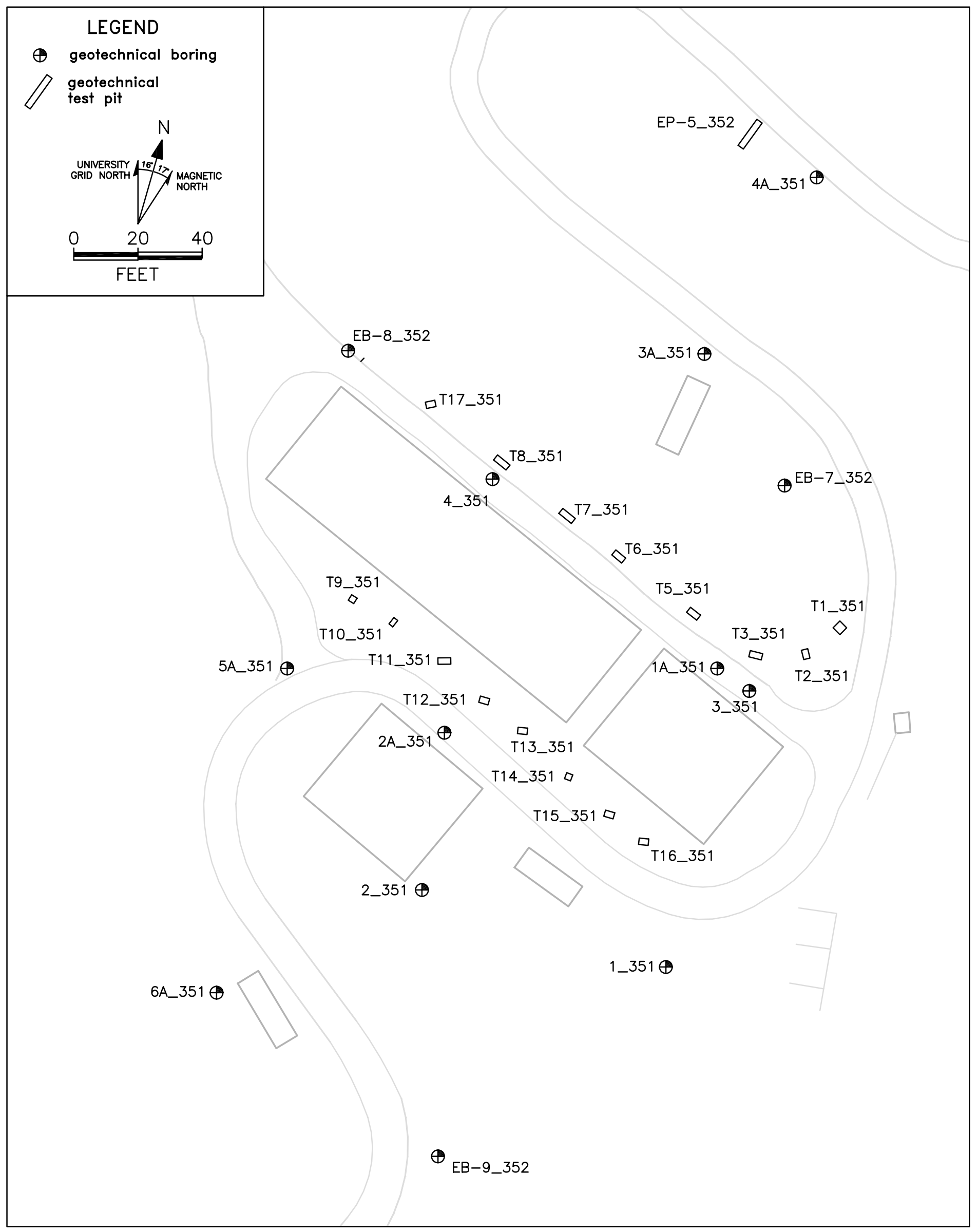

Figure 3-2c. Borings and test pits in the central lower portion of Chicken Creek canyon. 


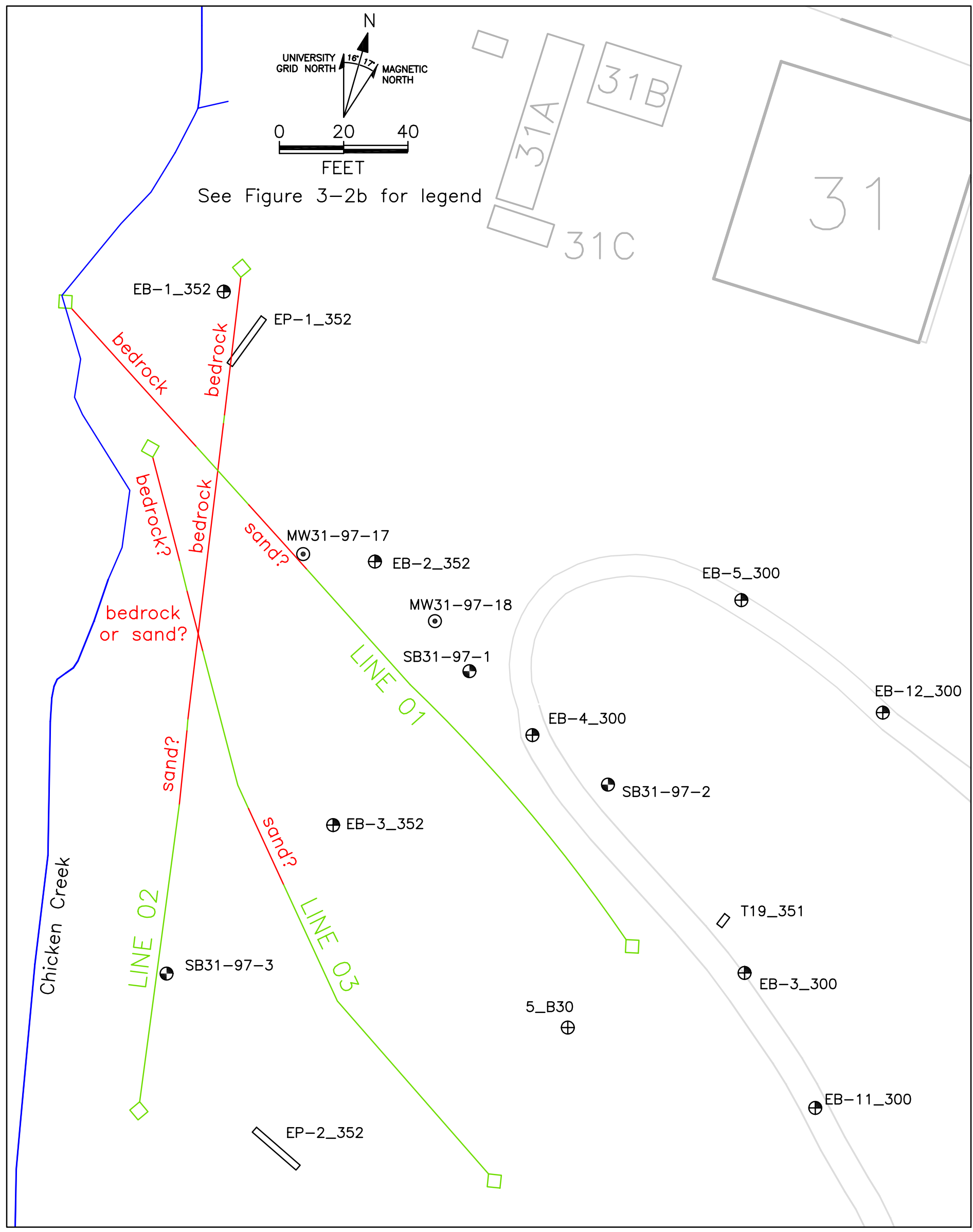

Figure 3-3. Electrical resistivity lines and previous borings in upper Chicken Creek canyon. Resistivity anomalies shown with initial interpretation of geologic features. 


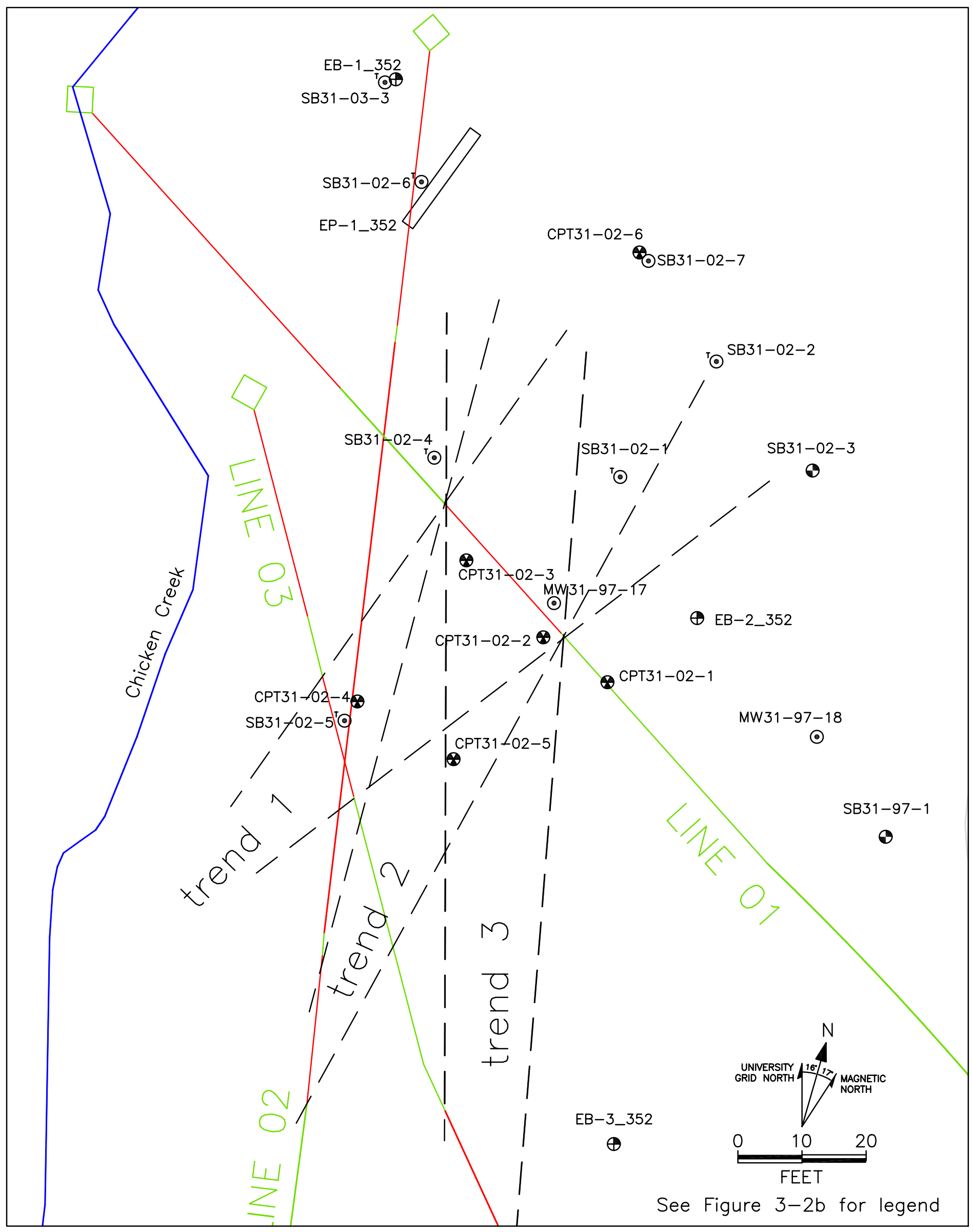

Figure 3-4. Potential sand body trends based upon electrical resistivity lines. Cone penetrometer test locations shown. 


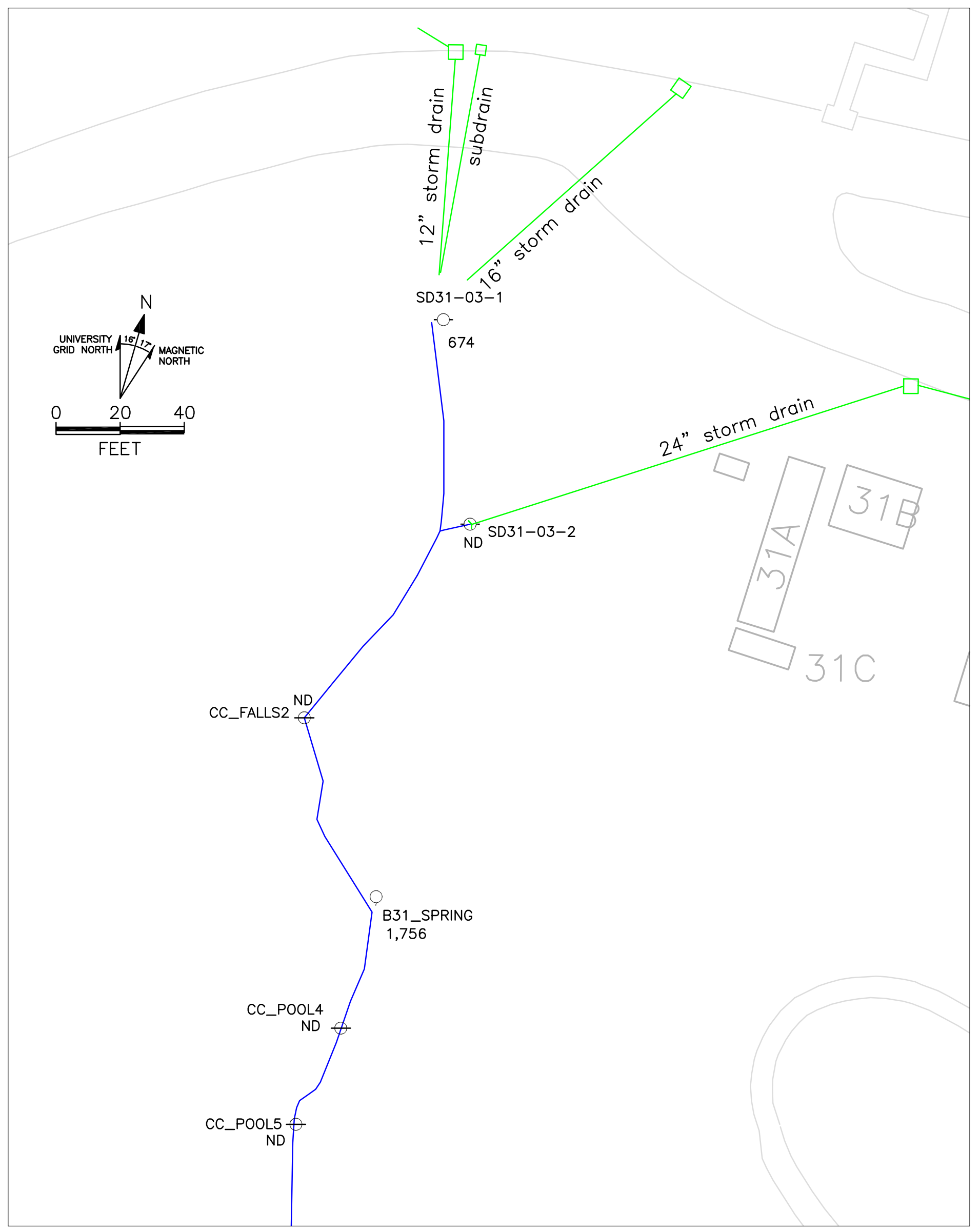

Figure 3-5. Tritium activities (pCi/L) in surface water samples from drain outfalls, Chicken Creek and a seep in upper Chicken Creek Canyon. "ND" indicates no tritium detected. 


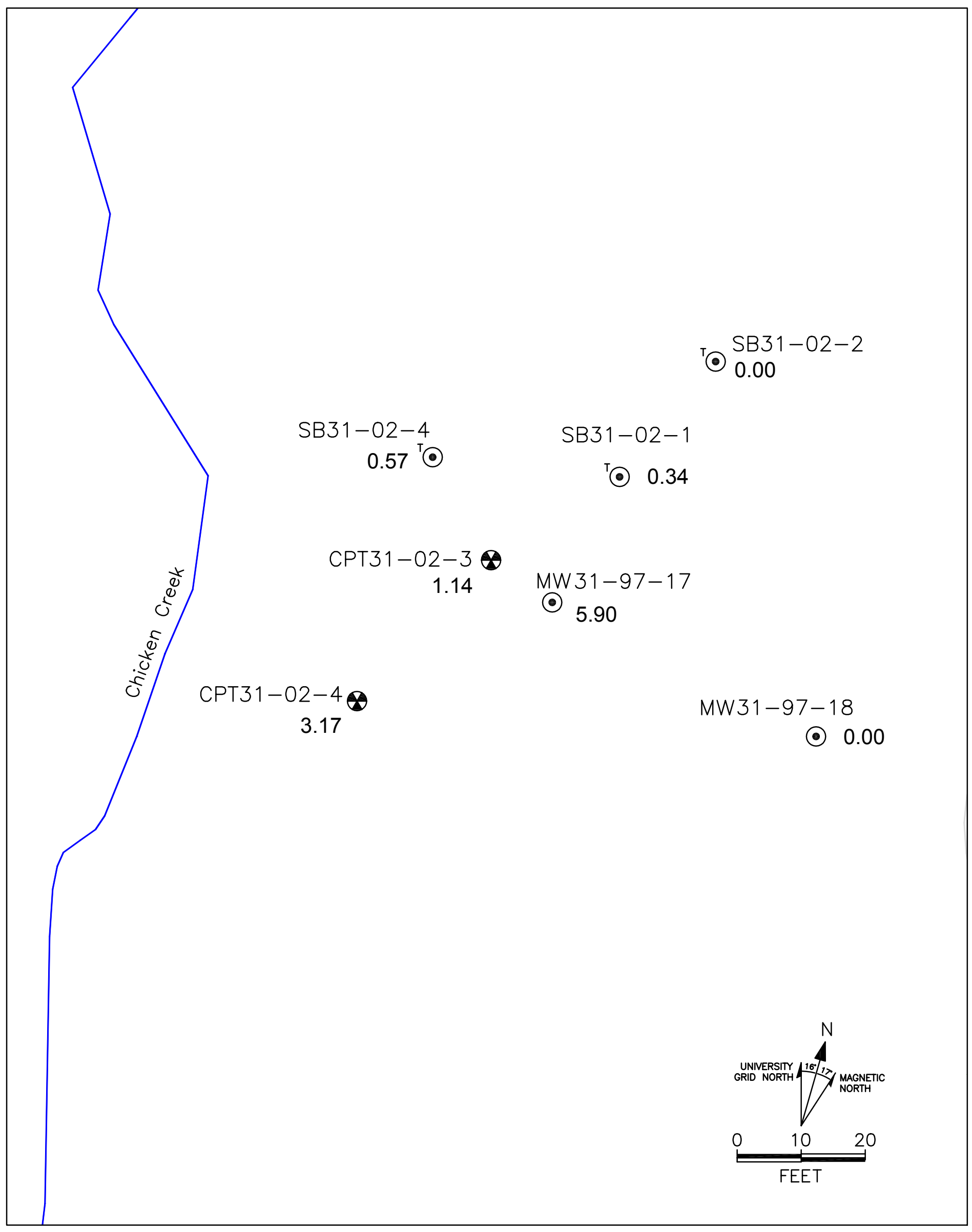

Figure 3-6. Drawdowns (feet) at the end of the October 21, 2002 pump test. 


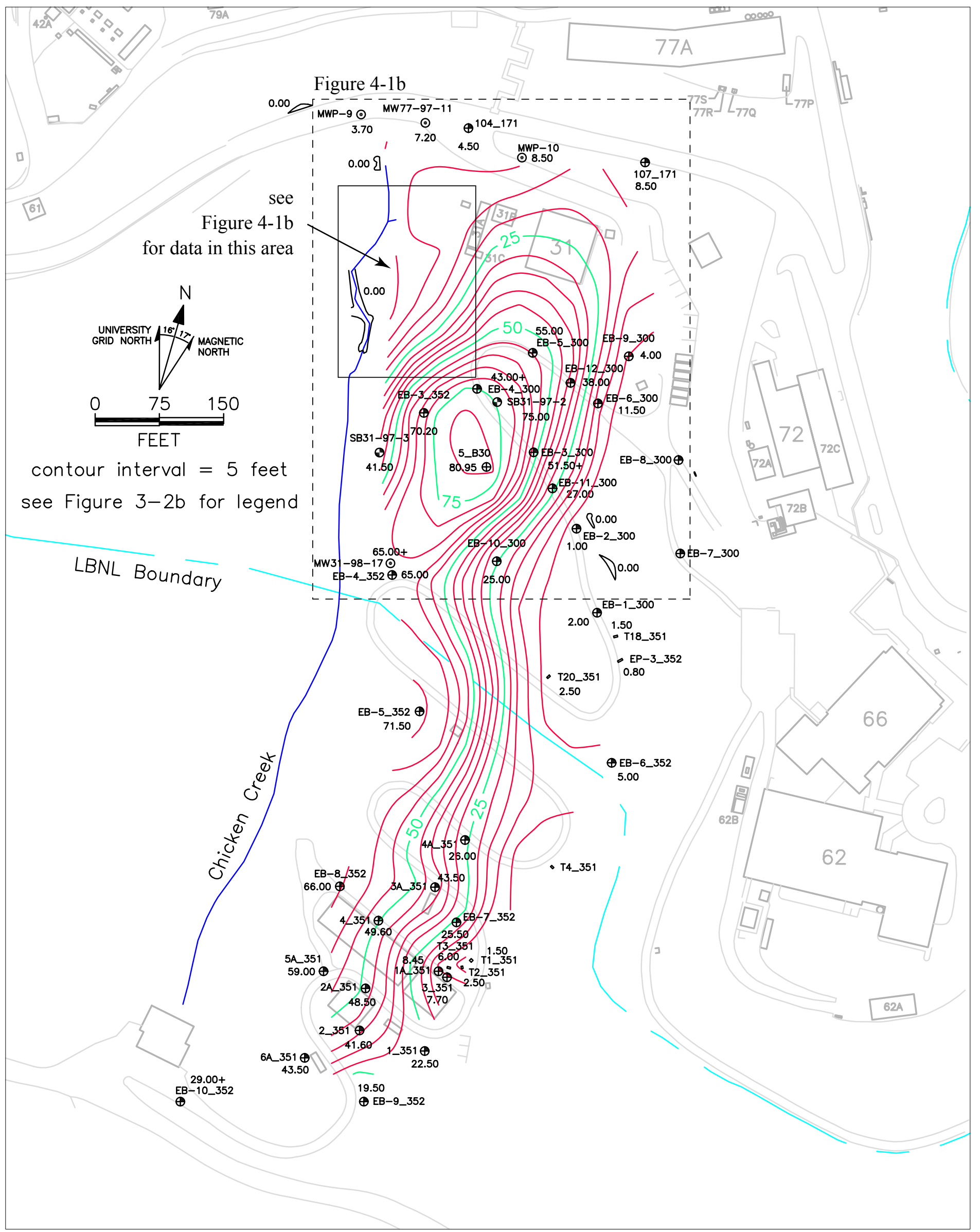

Figure 4-1a. Isopach map of undivided Quaternary soil deposits in Chicken Creek canyon. 


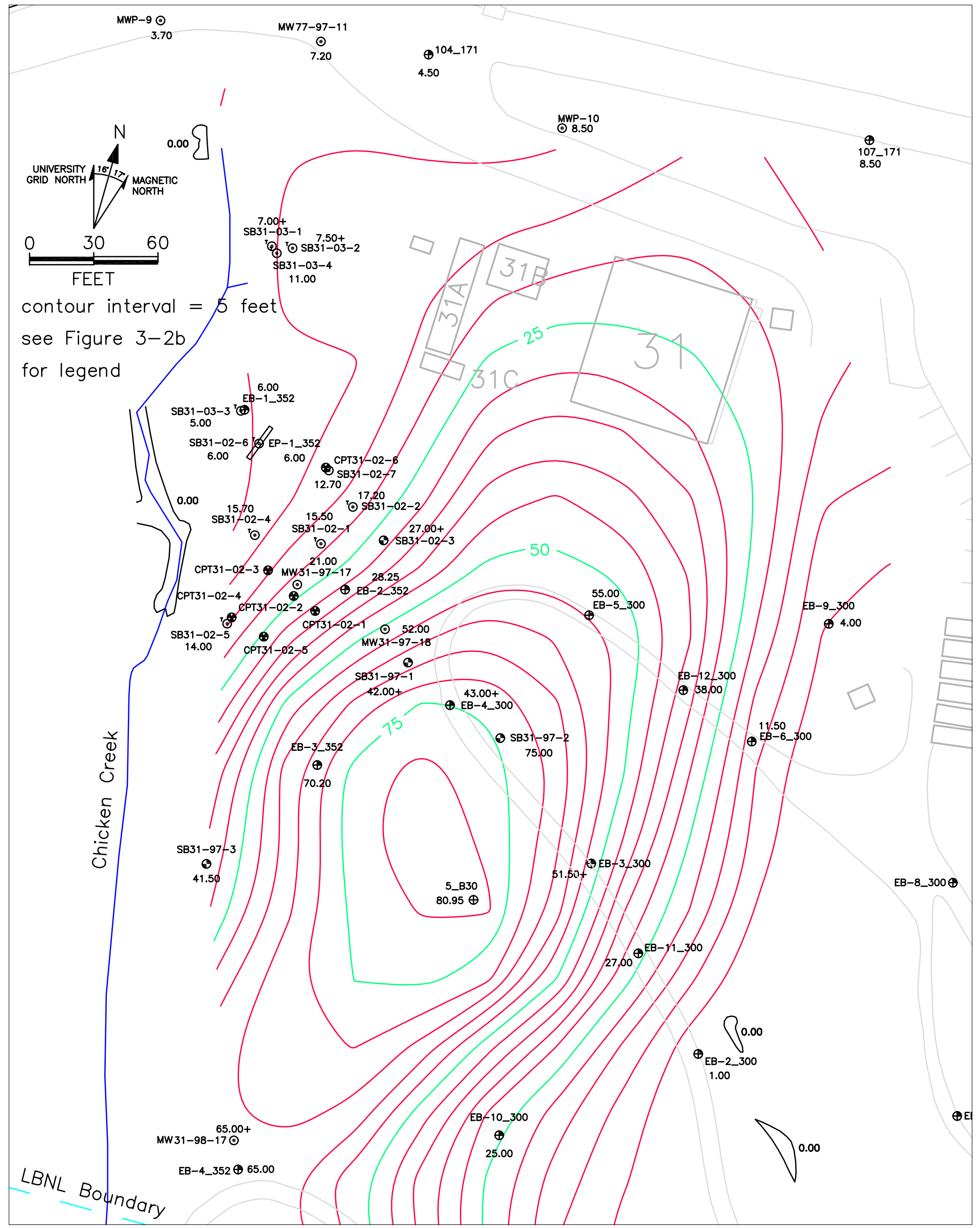

Figure 4-1b. Isopach map of undivided Quaternary soil deposits in upper Chicken Creek canyon. 


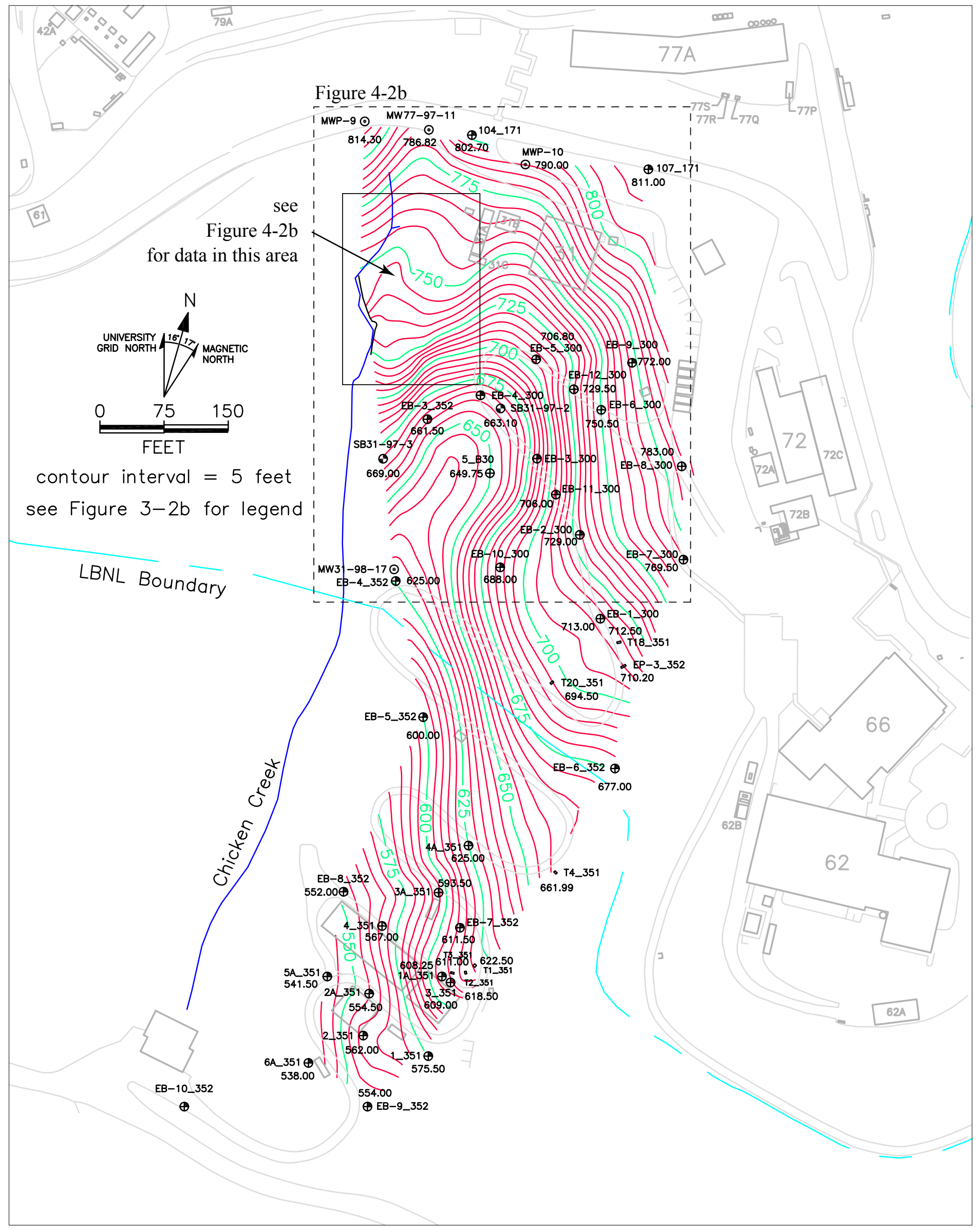

Figure 4-2a. Structure map of the top of bedrock in Chicken Creek canyon. Contouring includes the top of bedrock elevation along the east bank of Chicken Creek. 


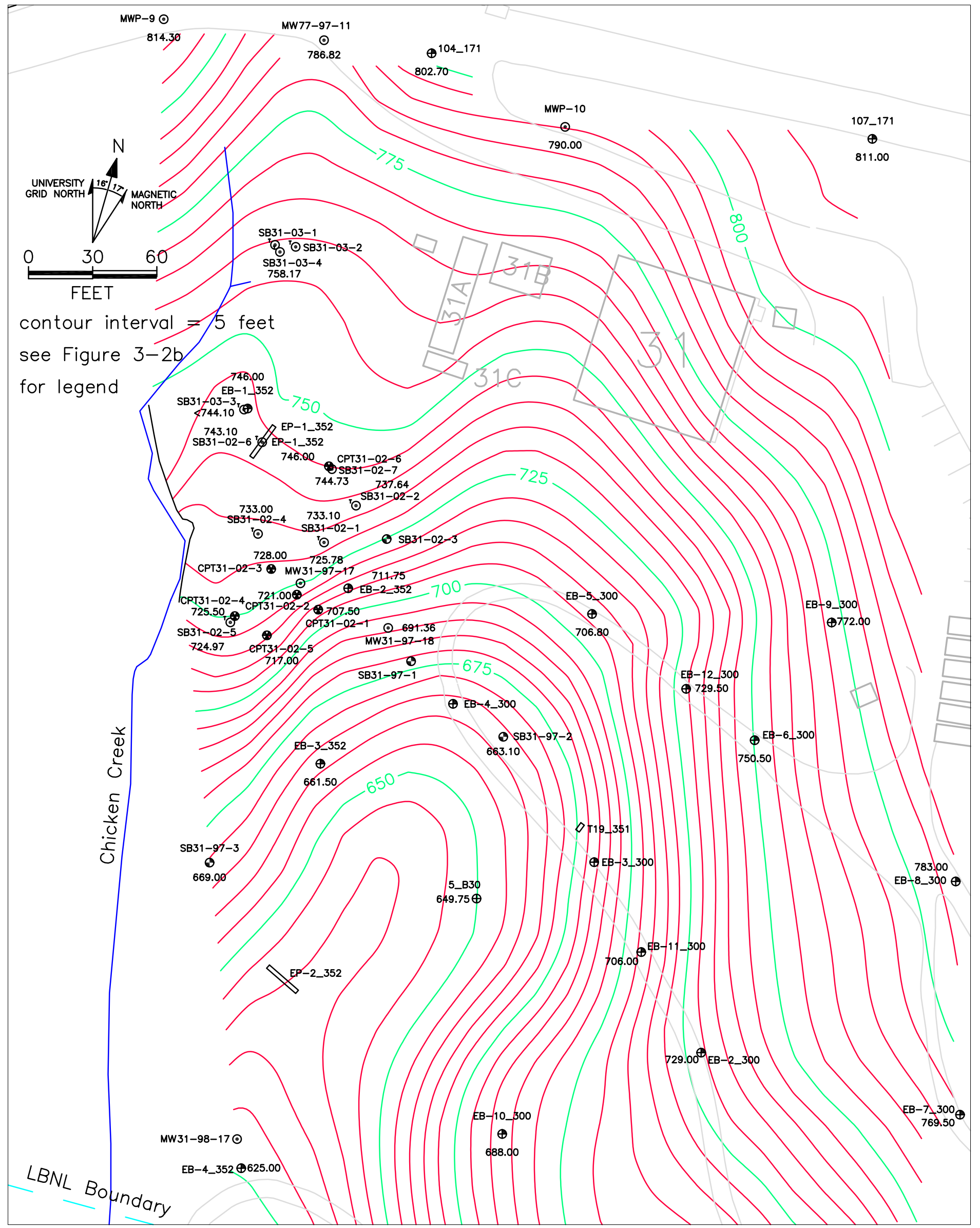

Figure 4-2b. Structure map of the top of bedrock in upper Chicken Creek canyon. Contouring includes the top of bedrock elevation along the east bank of Chicken Creek. 


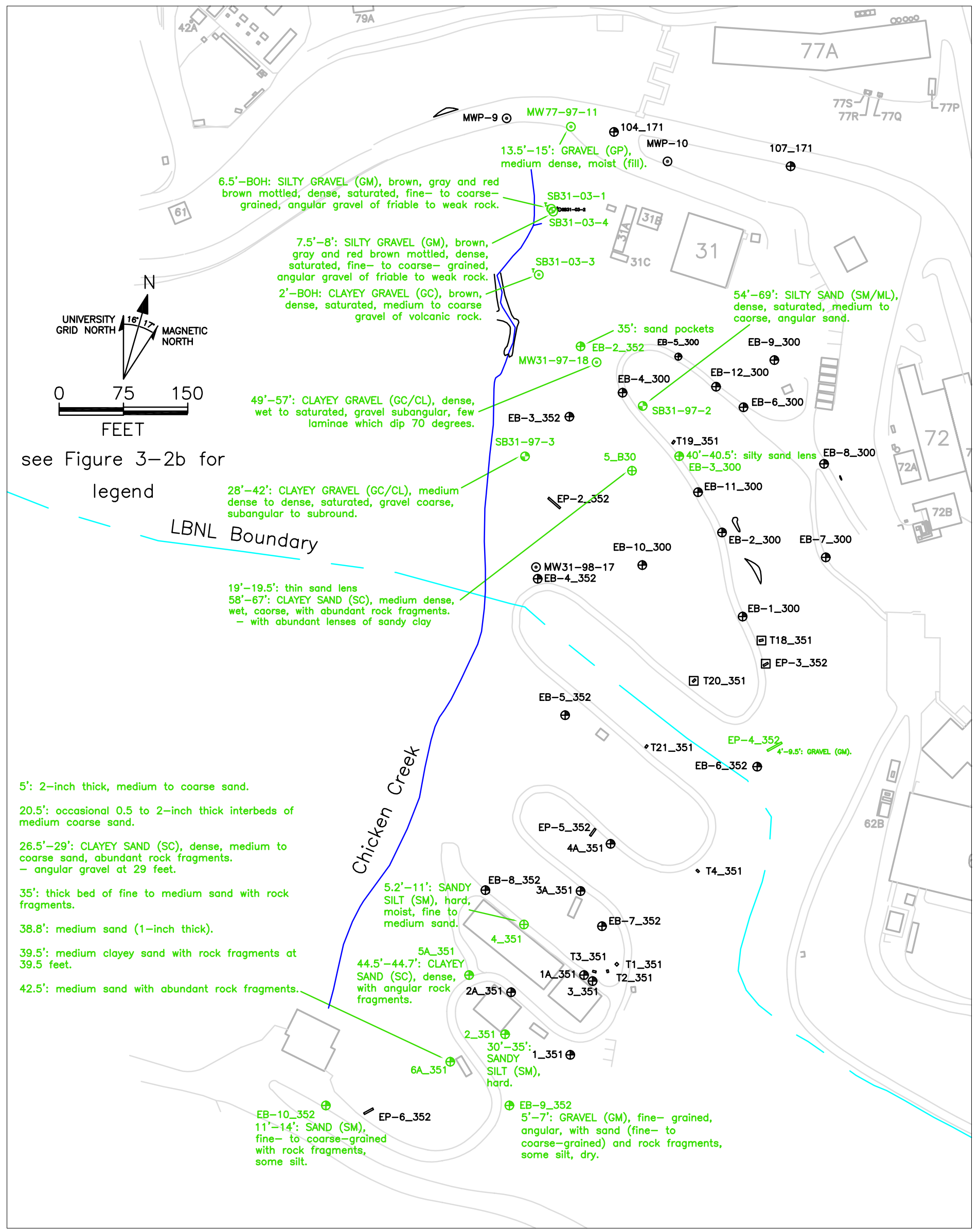

Figure 4-3. Borings that encountered coarse-grained soils shown in green along with descriptions of these soils. Some, but not all, sites not encountering only fine-grained soils are shown. 


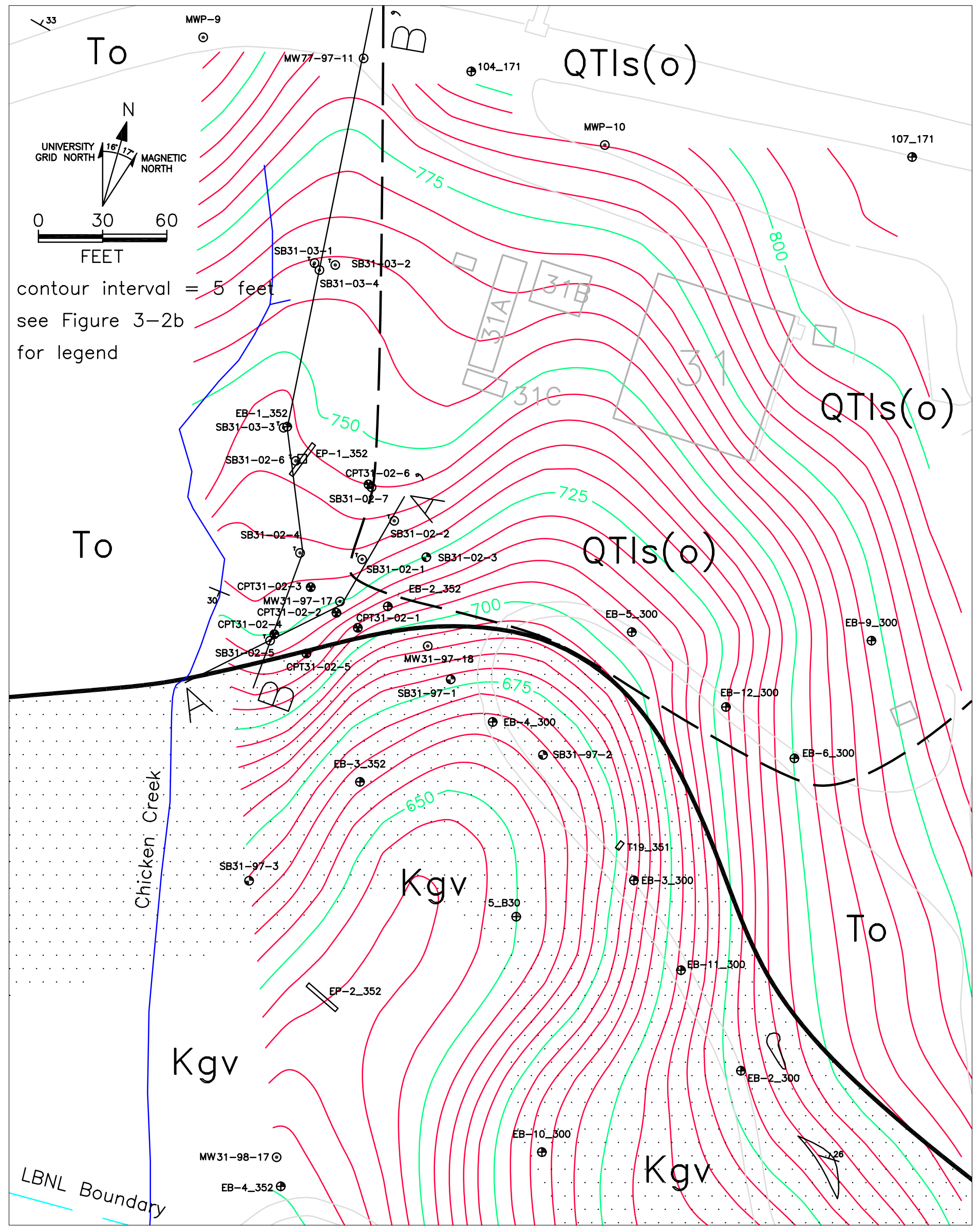

Figure 4-4. Bedrock geology in upper Chicken Creek canyon with top of bedrock structure map. The key to the bedrock units is in the caption for Figure 4-5. The heavy line represents a fault; the dashed line is an approximately located geologic contact. Stippling represents likely fault-sheared Kgv. 

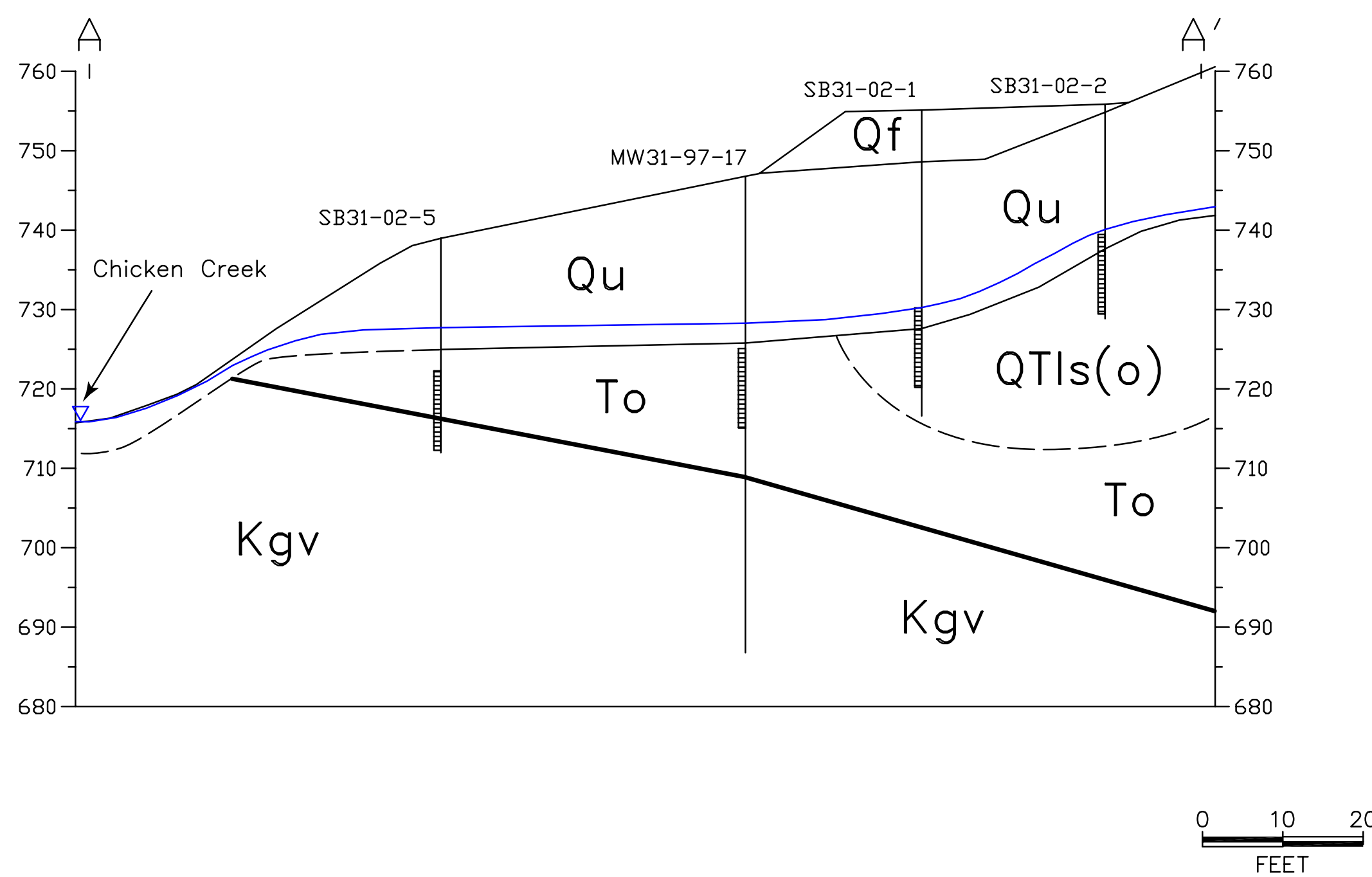

no vertical exaggeration

Figure 4-5. Section A-A' with April, 2003, water table. Qf = artificial fill, Qu = natural soil deposits, QTls(o)= paleolandslide deposits derived from the Orinda Formation, To = Orinda Formation, $\mathrm{Kgv}=$ Great Valley Group. The heavy line represents a fault; dashed lines represent approximately located contacts. 

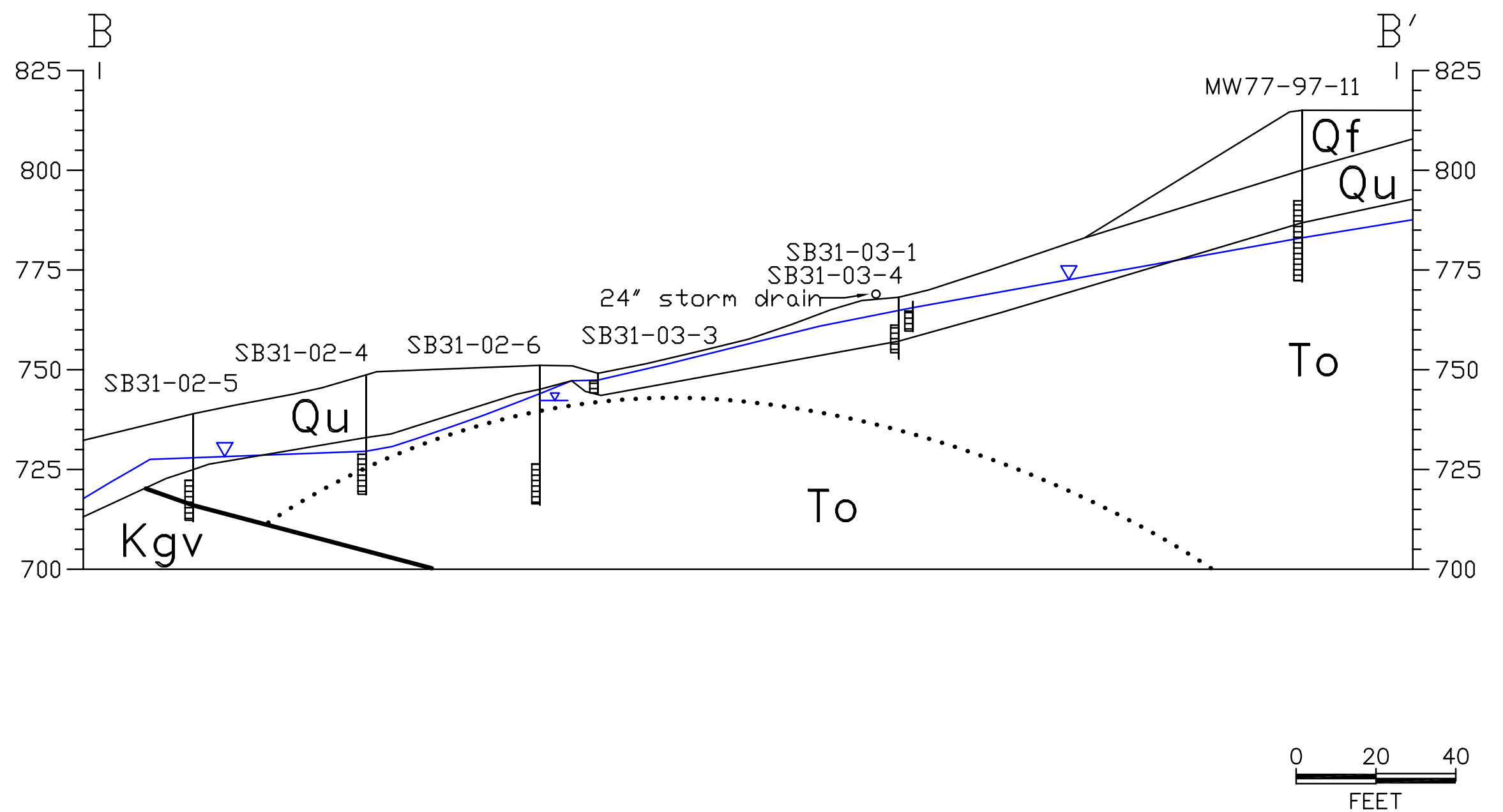

no vertical exaggeration

Figure 4-6. Section B-B' with April, 2003, water table. The key to the geologic units is in the caption for Figure 4-5. The heavy line represents a fault; the dotted line represents a possible anticline. 
distance from $\mathrm{To} / \mathrm{Kgv}$ contact $(\mathrm{ft})$

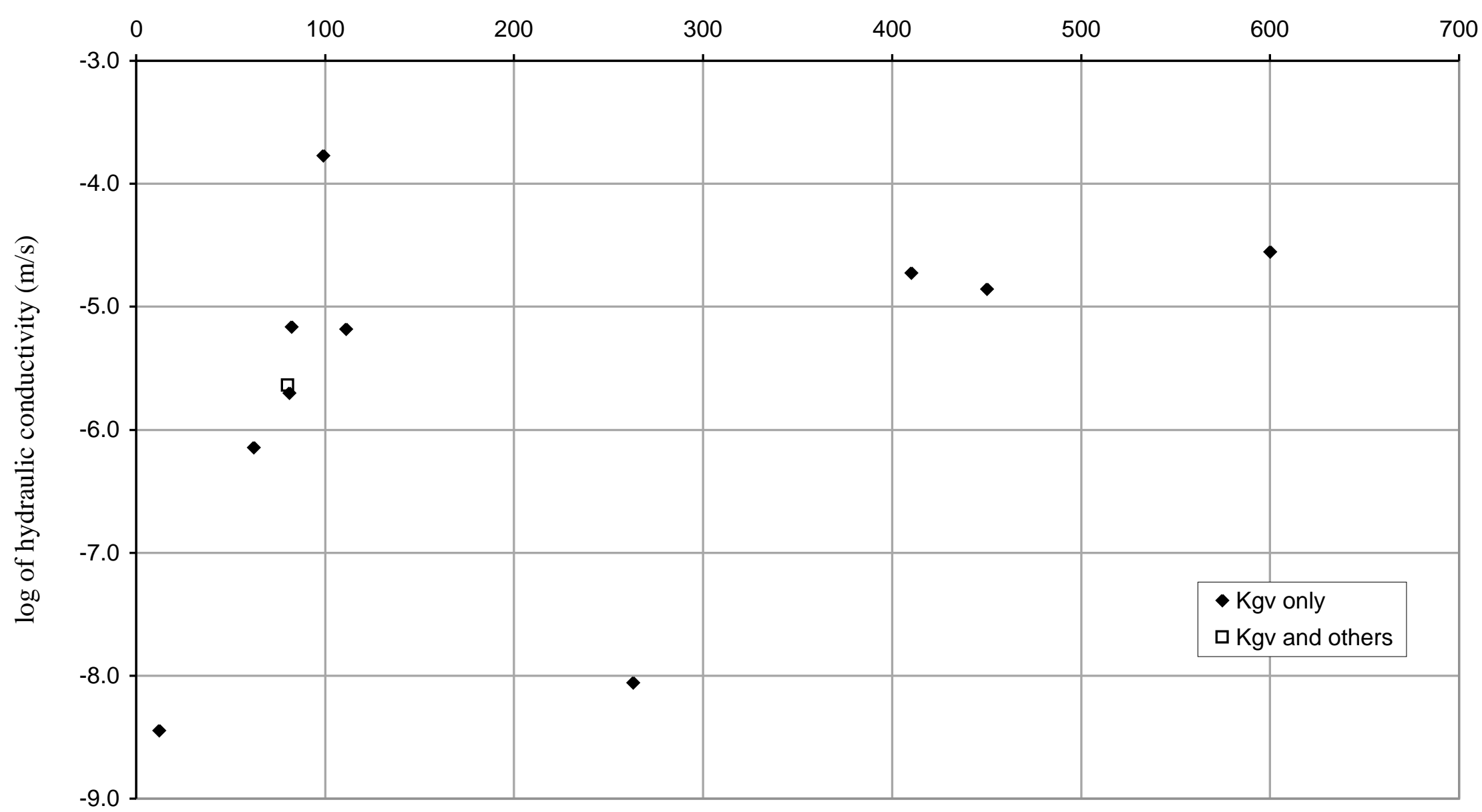

Figure 4-7. Variation of hydraulic conductivity in the Great Valley Group with distance from the Great Valley Group/Orinda Formation contact. 


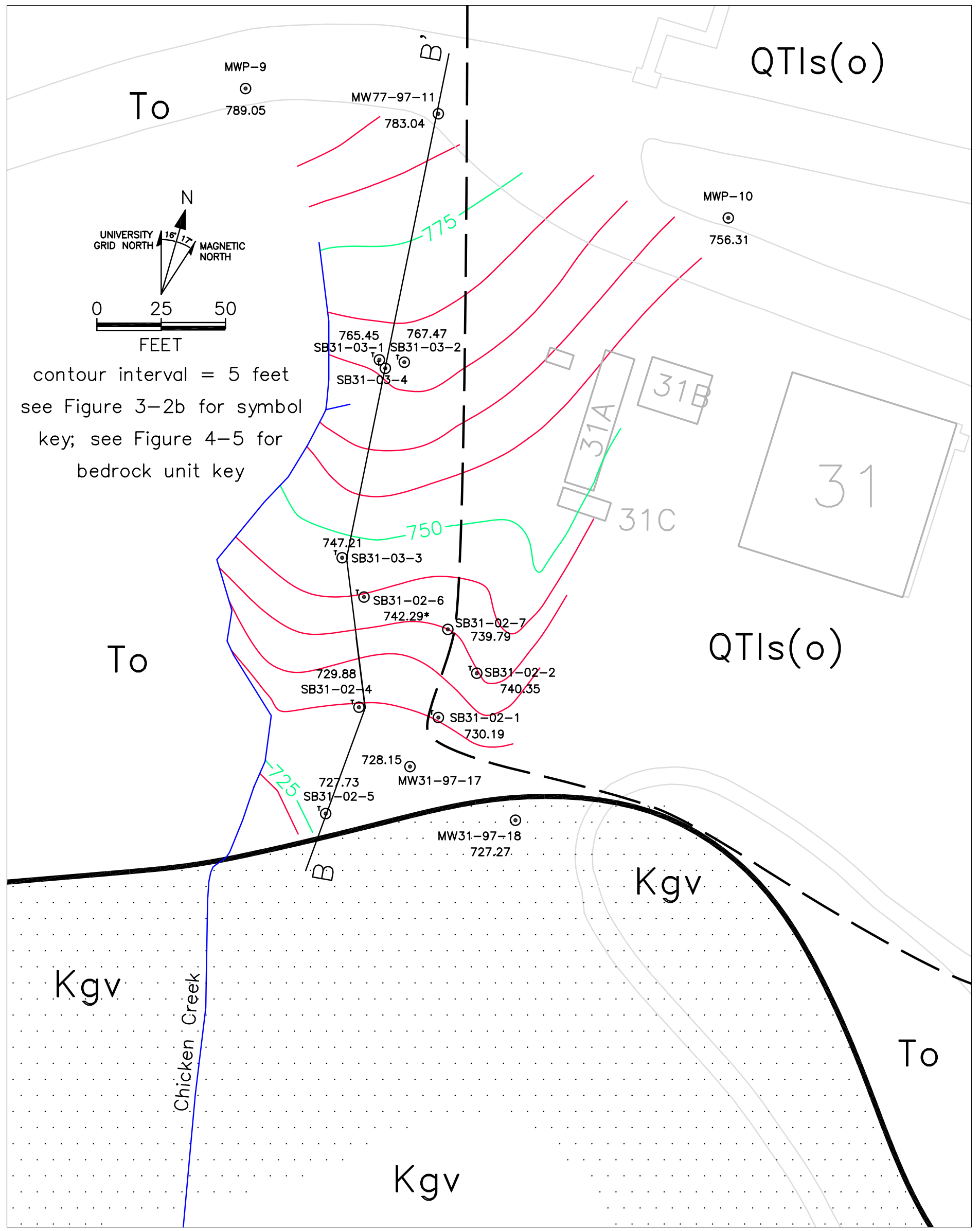

Figure 4-8. Water table in western upper Chicken Creek canyon using April, 2003, water levels. Bedrock geology shown. Water surface elevation in creek at base flow used for contouring. Water level with asterisk not used for contouring. 


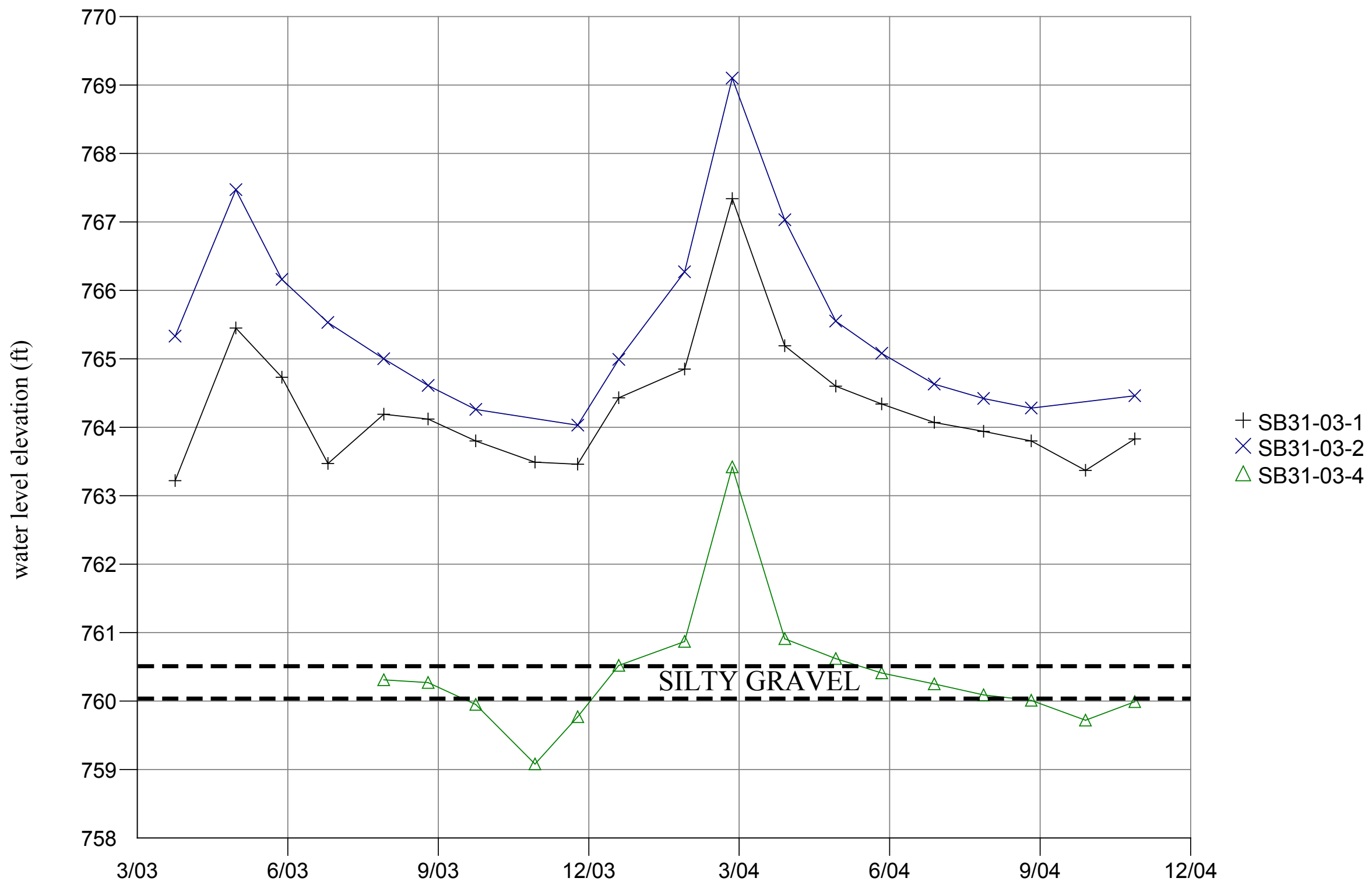

Figure 4-9. Hydrographs for SB31-03-1, SB31-03-2 and SB31-03-4. 


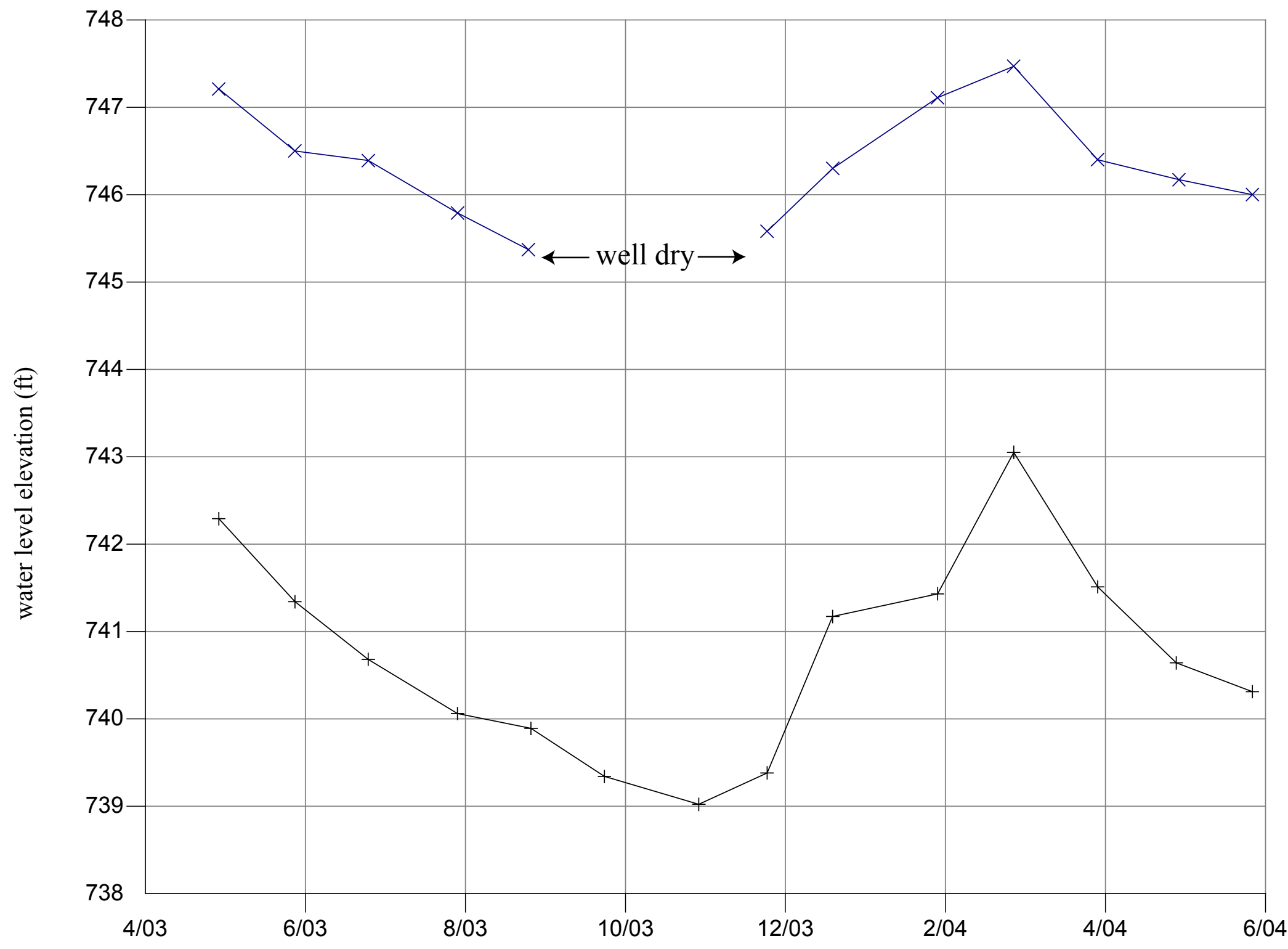

+ SB31-02-6

$\times$ SB31-03-3

Figure 4-10. Hydrographs for SB31-02-6 and SB31-03-3. 


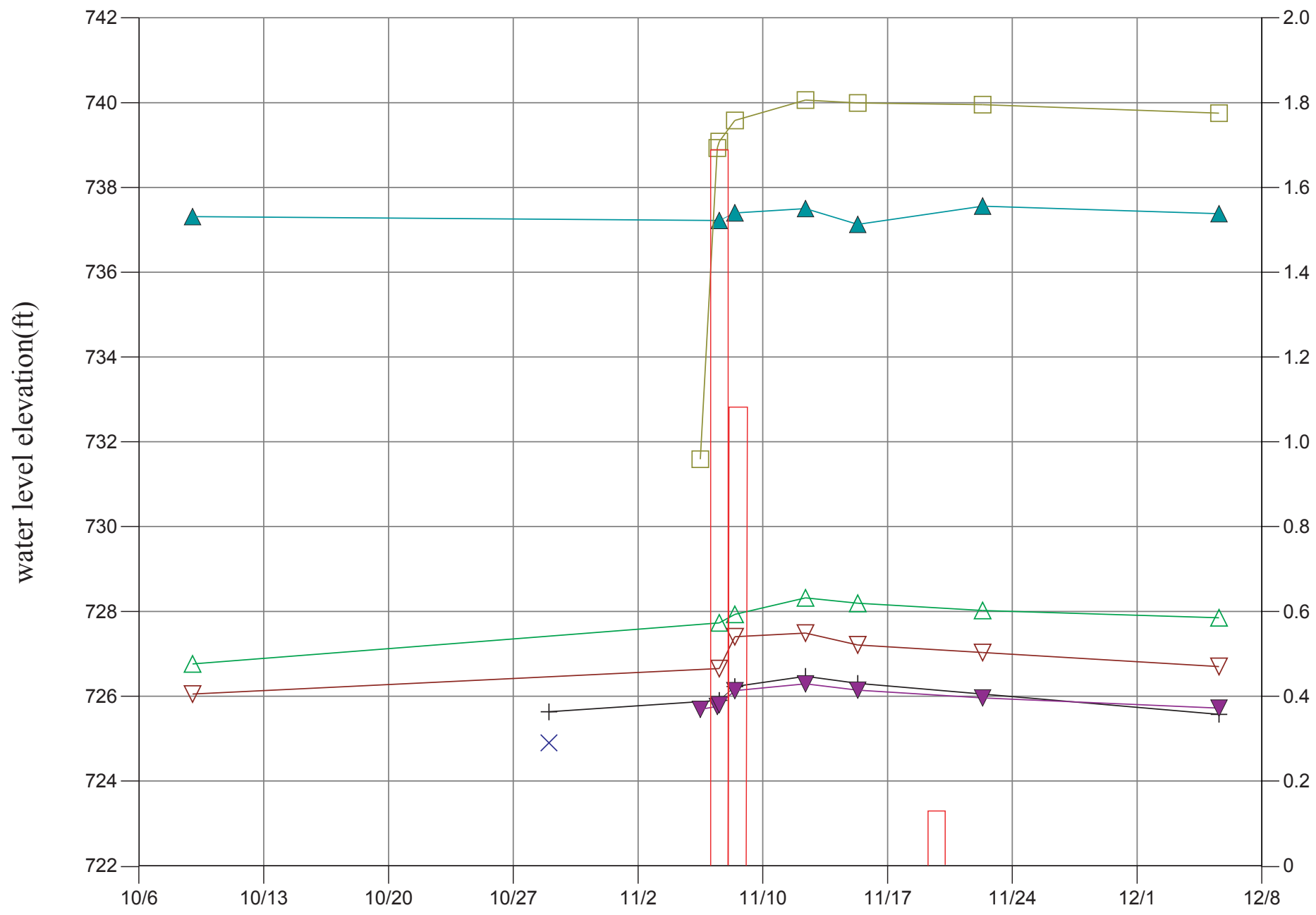

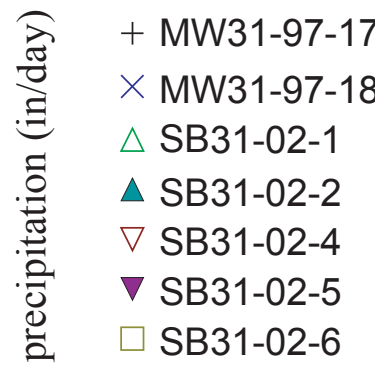

Figure 4-11. Hydrographs for MW31-97-17 and nearby wells with daily precipitation overlain. 


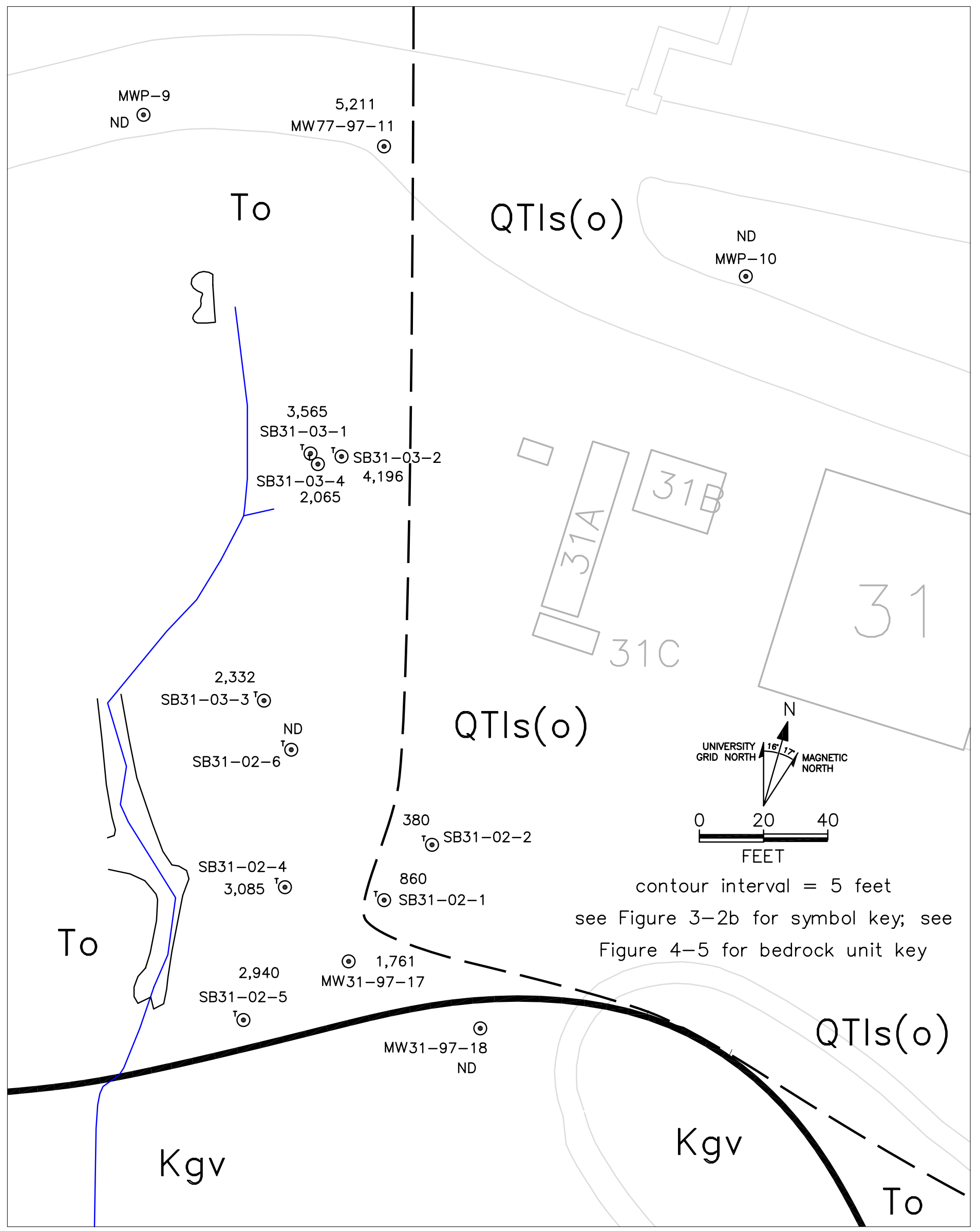

Figure 4-12. Groundwater tritium activities $(\mathrm{pCi} / \mathrm{L})$ in upper Chicken Creek canyon in the fourth quarter, fiscal year 2003 (July through September, 2003). Bedrock geology shown. "ND" indicates no tritium detected. 


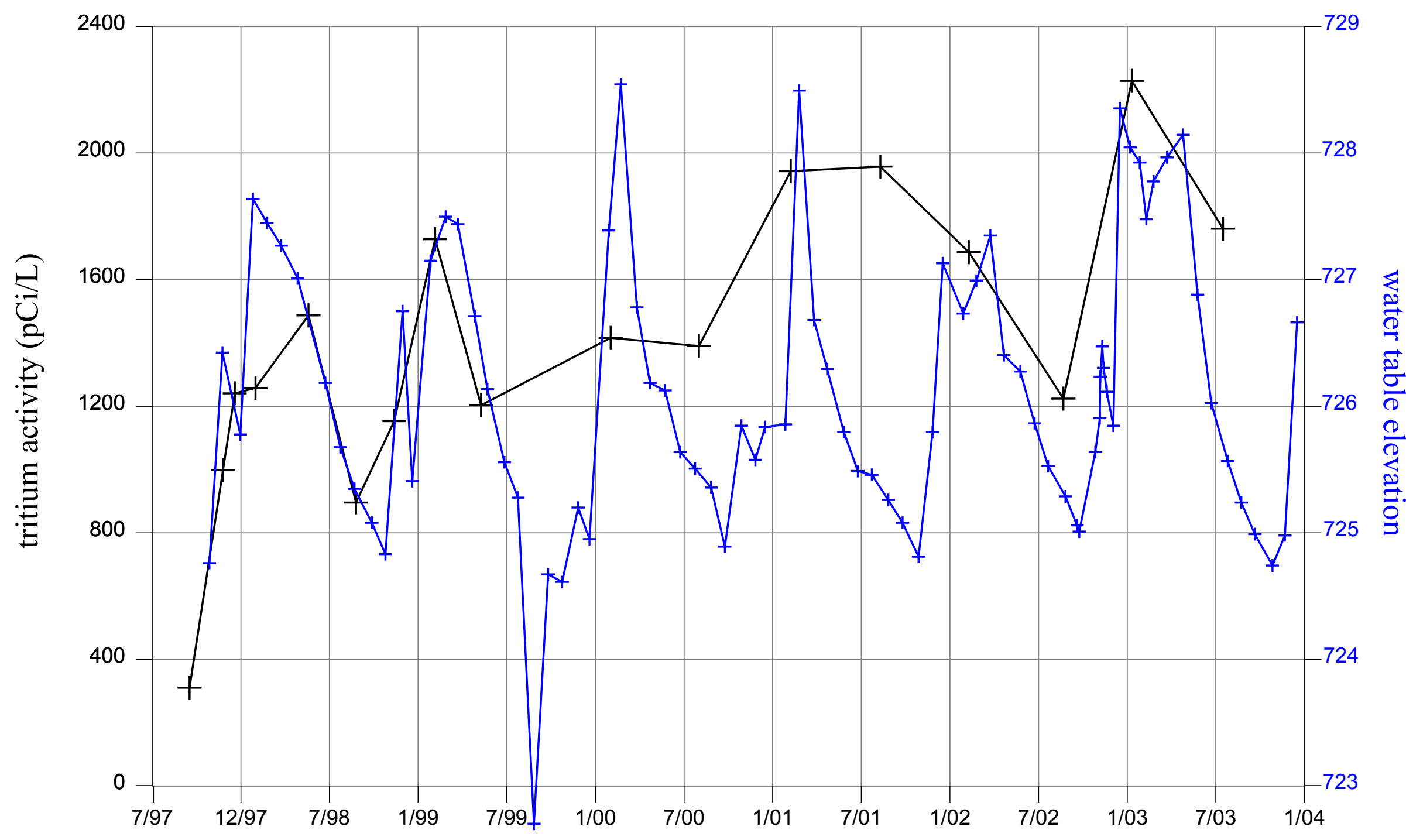

Figure 4-13. Groundwater tritium activities and water table elevation in MW31-97-17. 


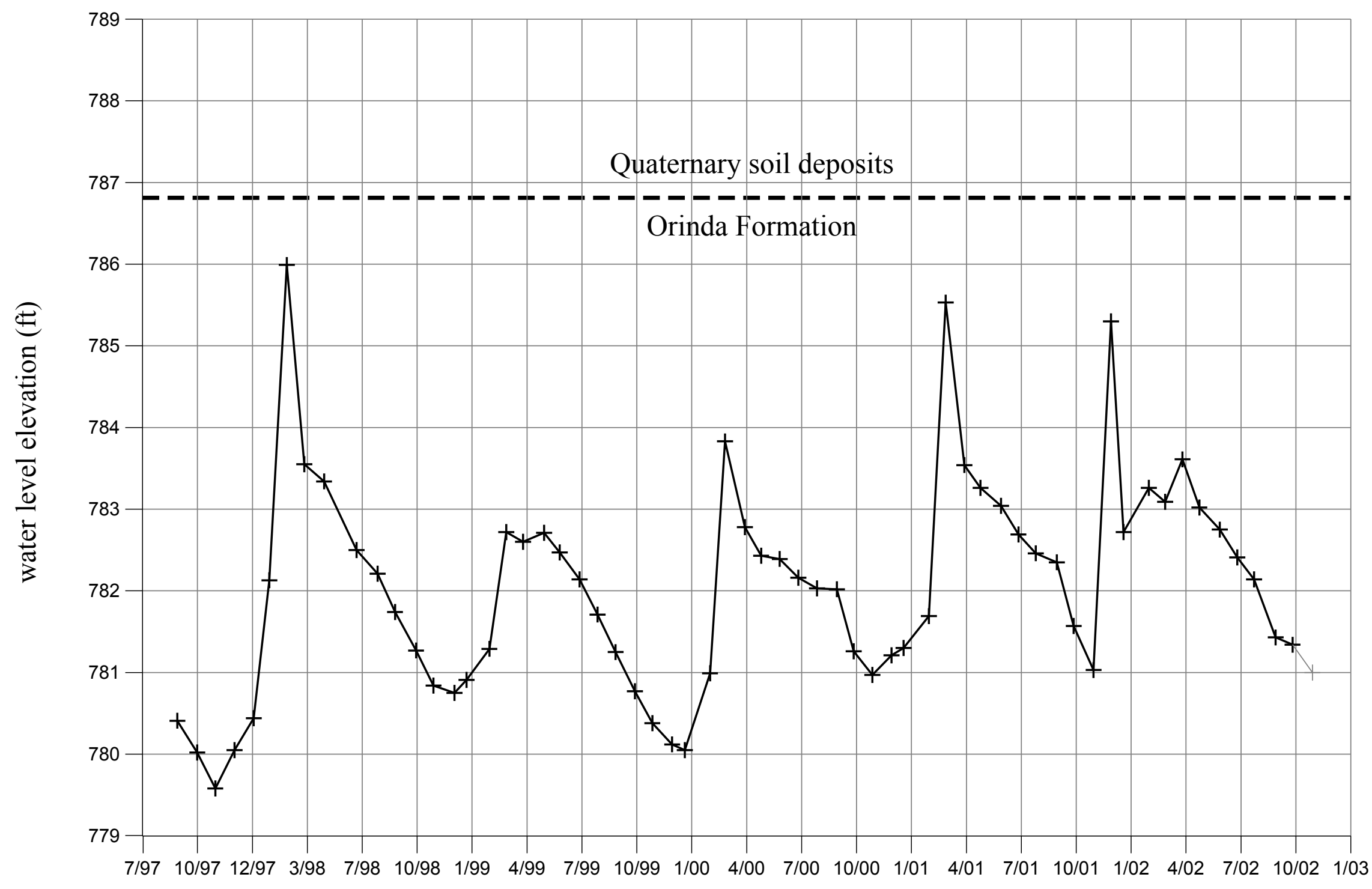

Figure 4-14. Hydrograph for MW77-97-11 with the top of the Orinda Formation shown. 
To $\stackrel{M W P-9}{\odot \text { ND }}$

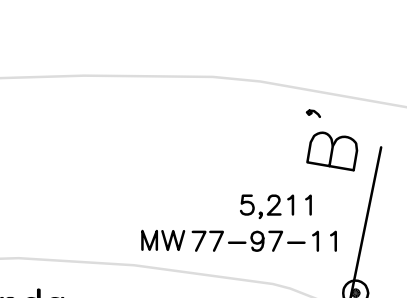

medium permeability Orinda sandstone - flow of tritiated groundwater into alluvial deposits

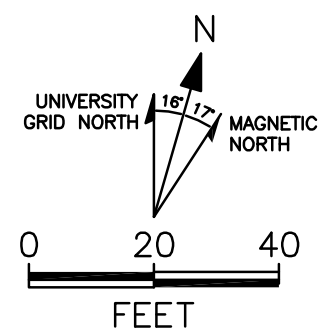

contour interval $=5$ feet see Figure 3-2b for symbol key; see

Figure 4-5 for bedrock unit key

high permeability alluvial deposits - little downward flow of tritiated groundwater into the Orinda Formation (possibly due to subhorizontal anisotropy)

tritiated groundwater seeps from base of alluvial deposits and flows downward into the Orinda Formation (possibly abetted by south-dipping anisotropy)

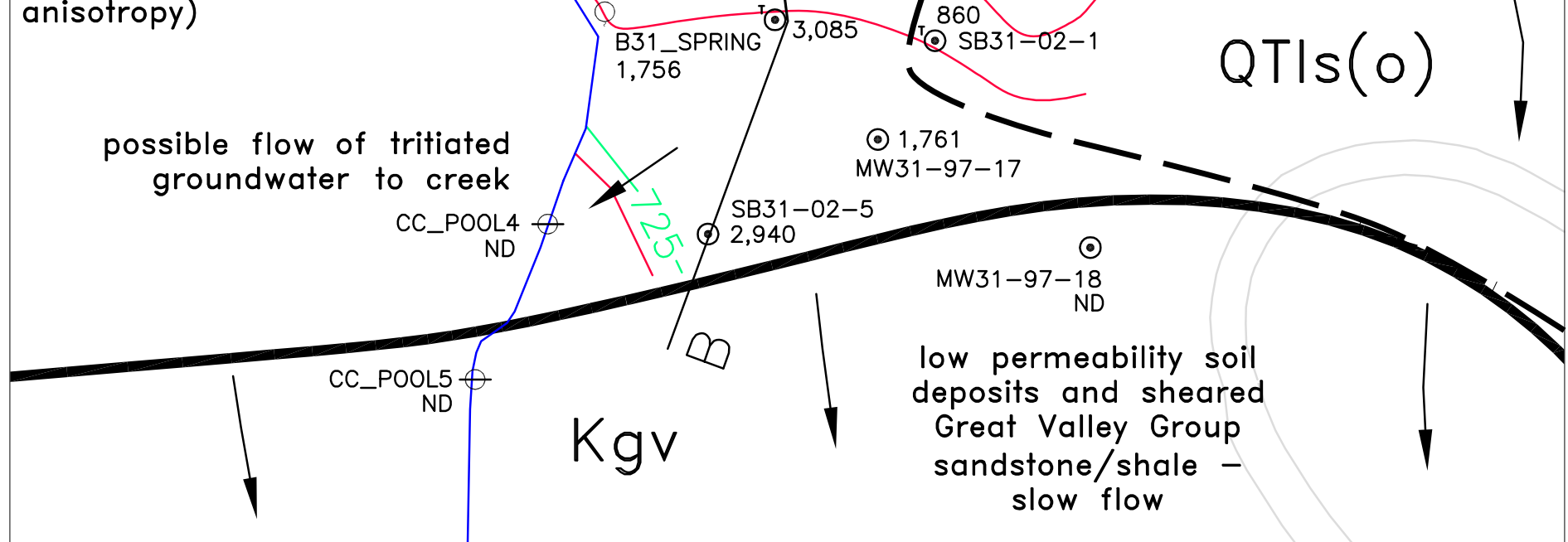

Figure 5-1. A plan view of the conceptual model of groundwater flow in upper Chicken Creek Canyon. Bedrock contacts and April, 2003, water table shown along with fourth quarter, fiscal year 2003 groundwater and February, 2003 surface water tritium activities. "ND" indicates no tritium detected. 


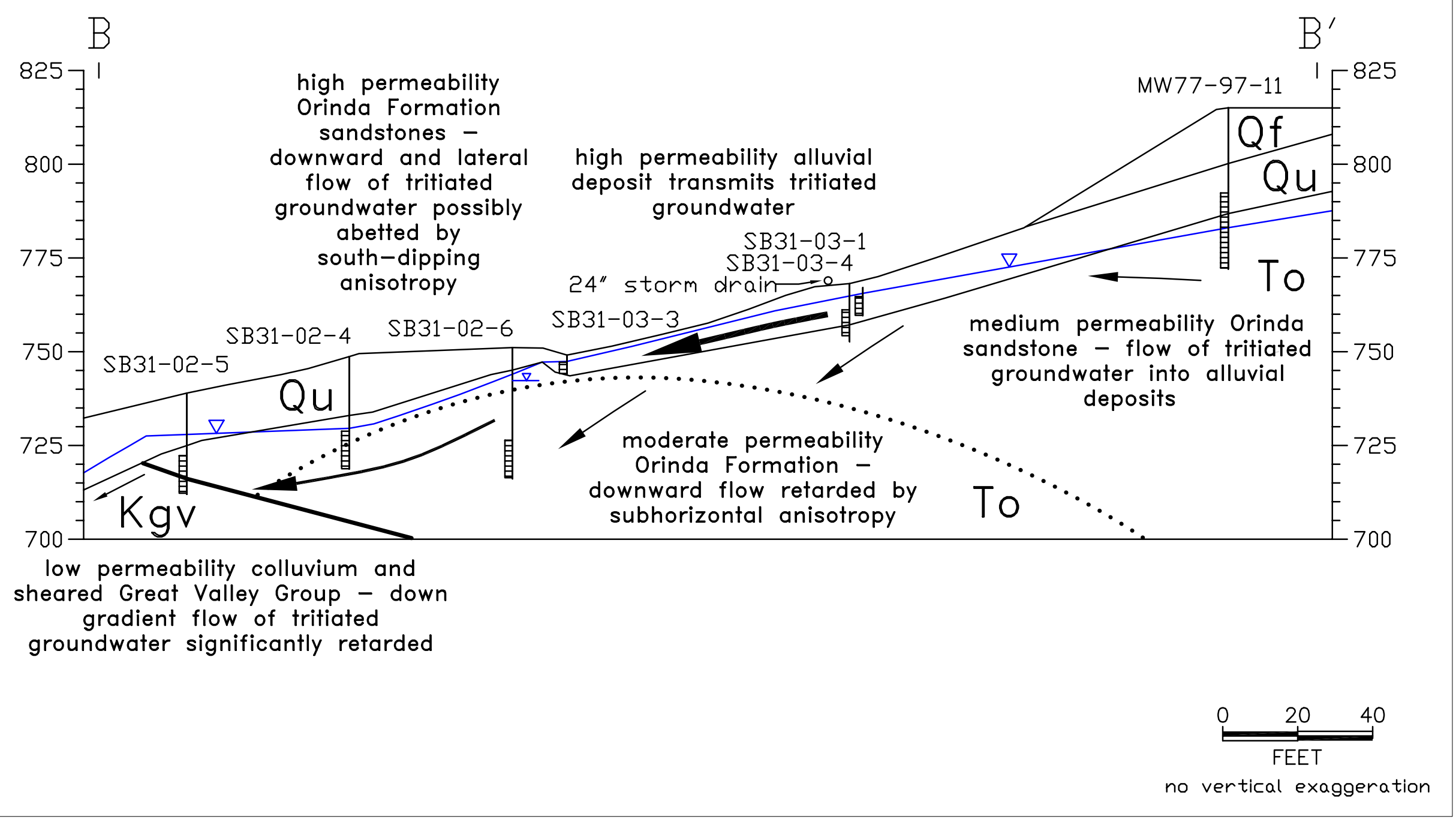

Figure 5-2. A cross section view of the conceptual model of groundwater flow in upper Chicken Creek canyon. Geologic contacts and April, 2003, water table shown. The key to the geologic units is in the caption for Figure 4-5. The heavy line represents a fault; the dotted line represents a possible anticline. 
APPENDIX 1: Electrical Resistivity Profiles 


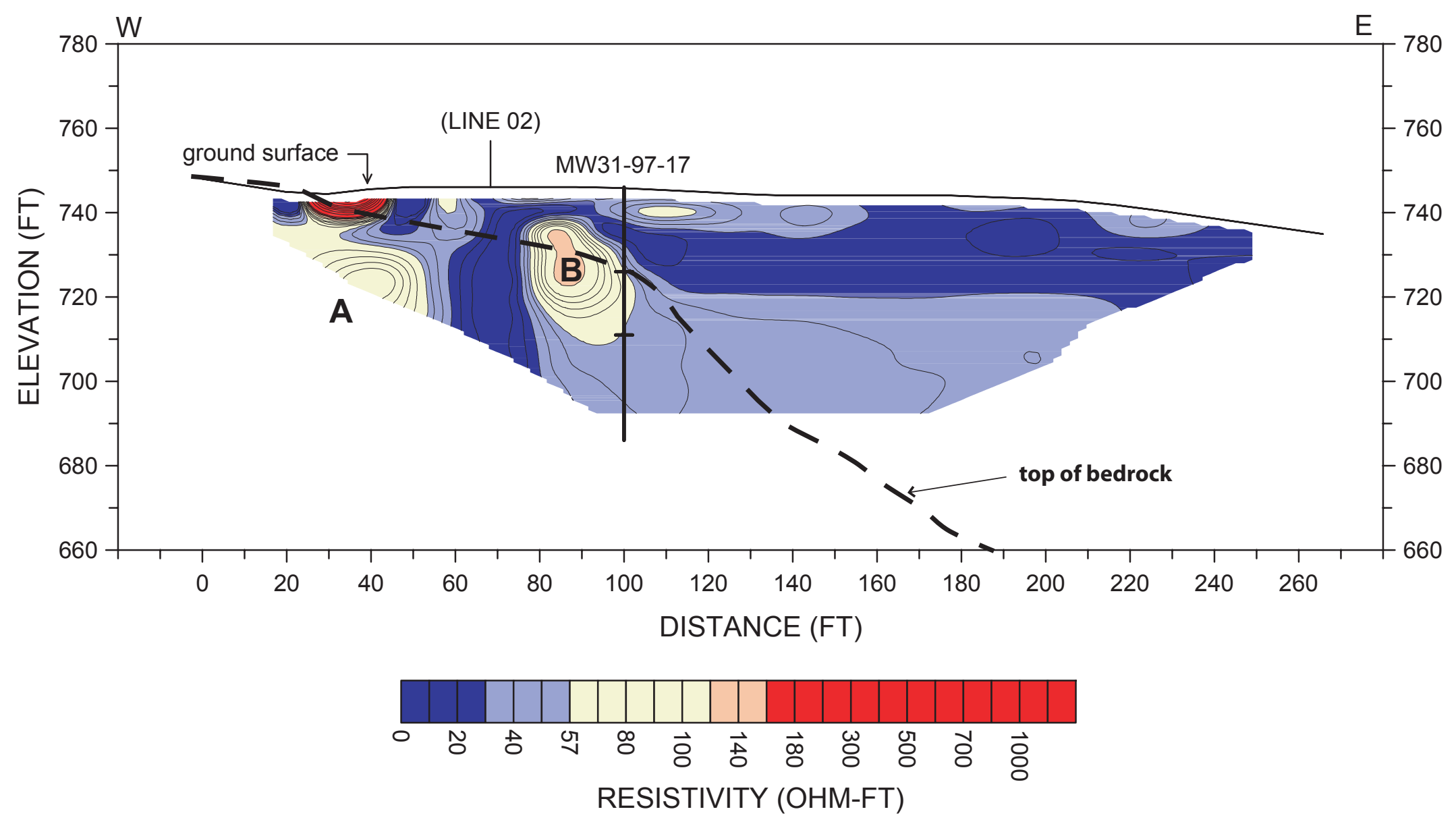

Inverted electrical resistivity results along line 01 . Top of bedrock from subsequent drilling (Figure 4-2b) shown as dashed line. 


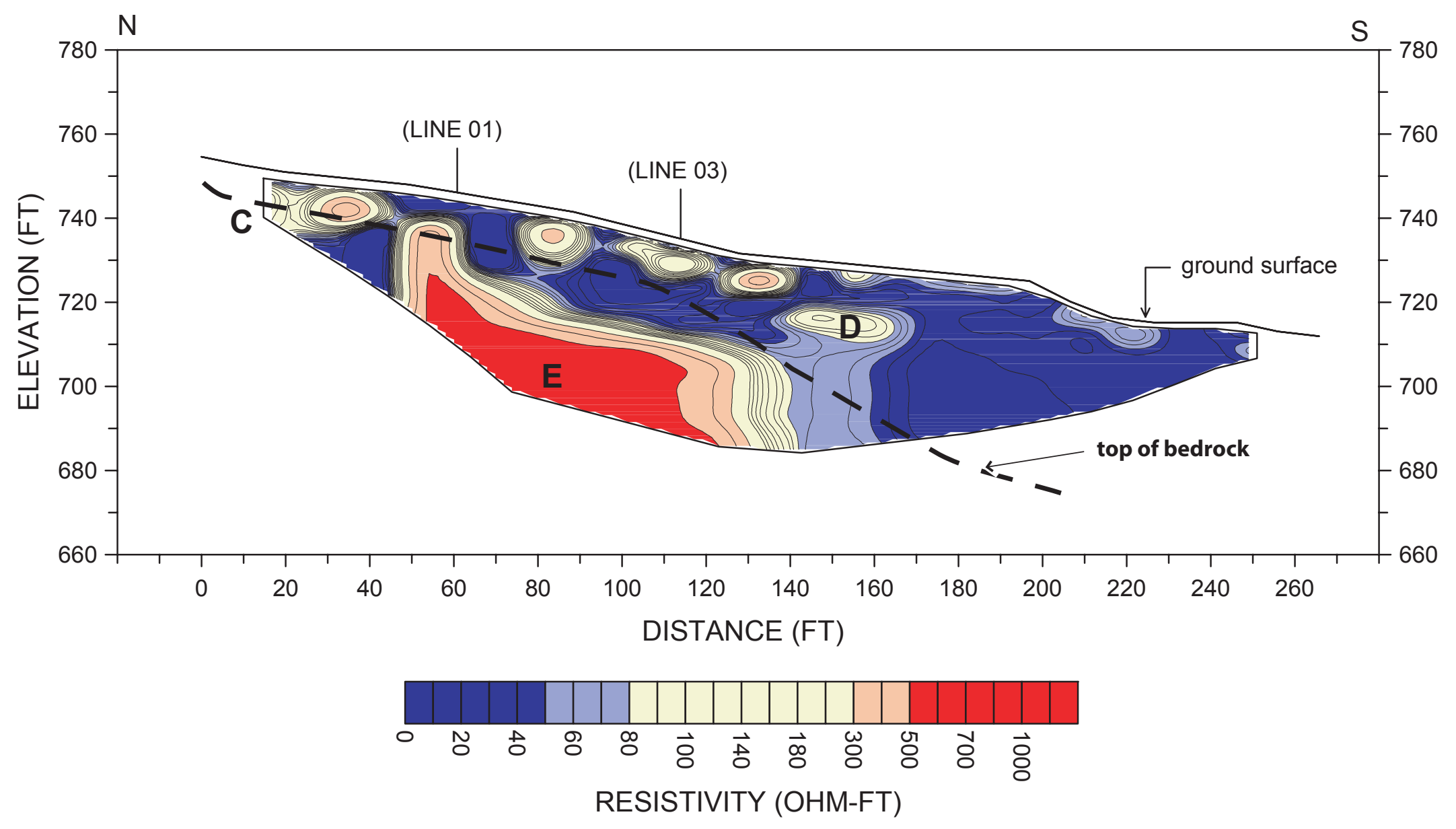

Inverted electrical resistivity results along line 02 . Top of bedrock from subsequent drilling (Figure 4-2b) shown as dashed line. 


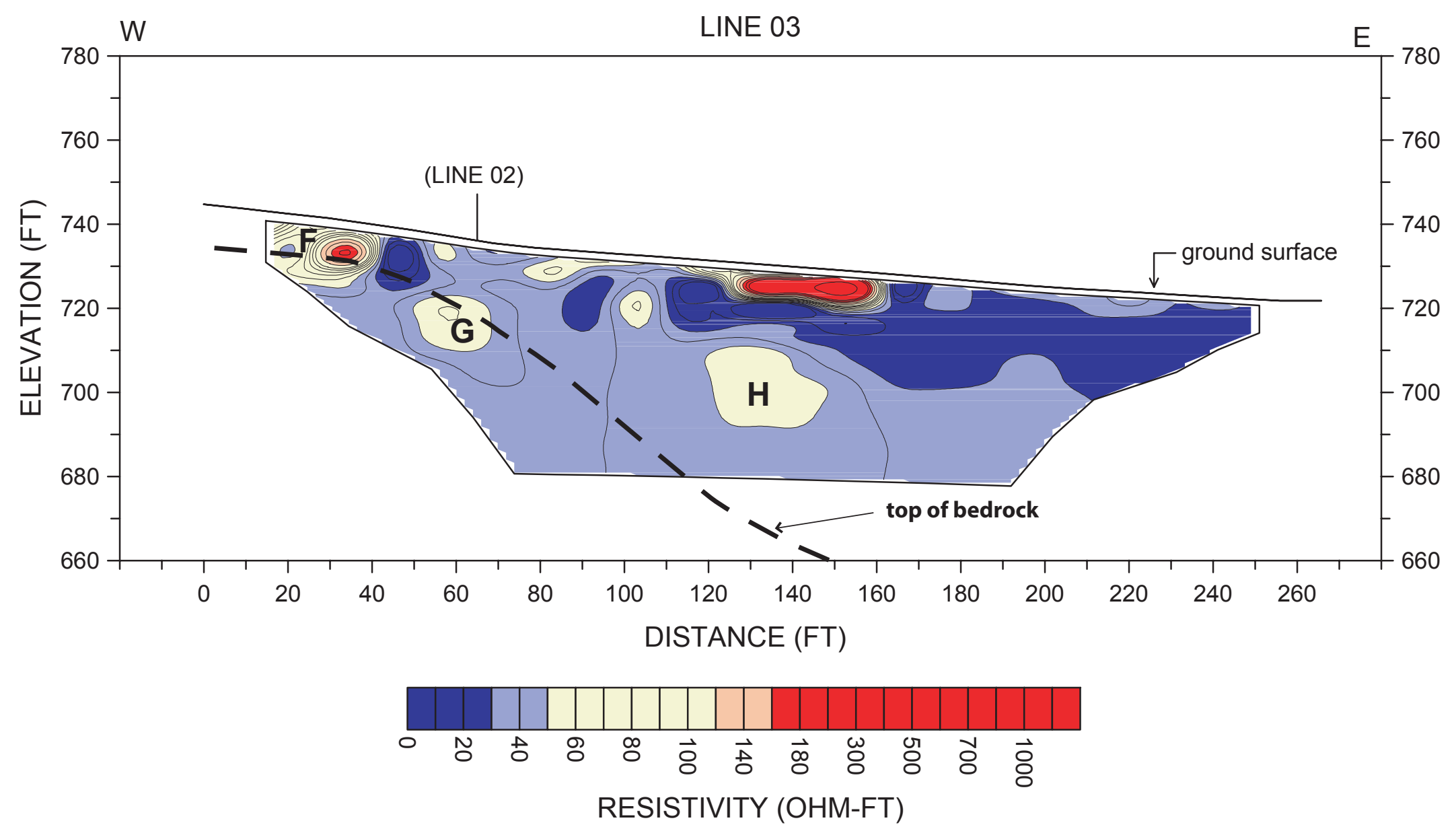

Inverted electrical resistivity results along line 03 . Top of bedrock from subsequent drilling (Figure 4-2b) shown as dashed line. 
APPENDIX 2: Cone Penetrometer Test Logs 


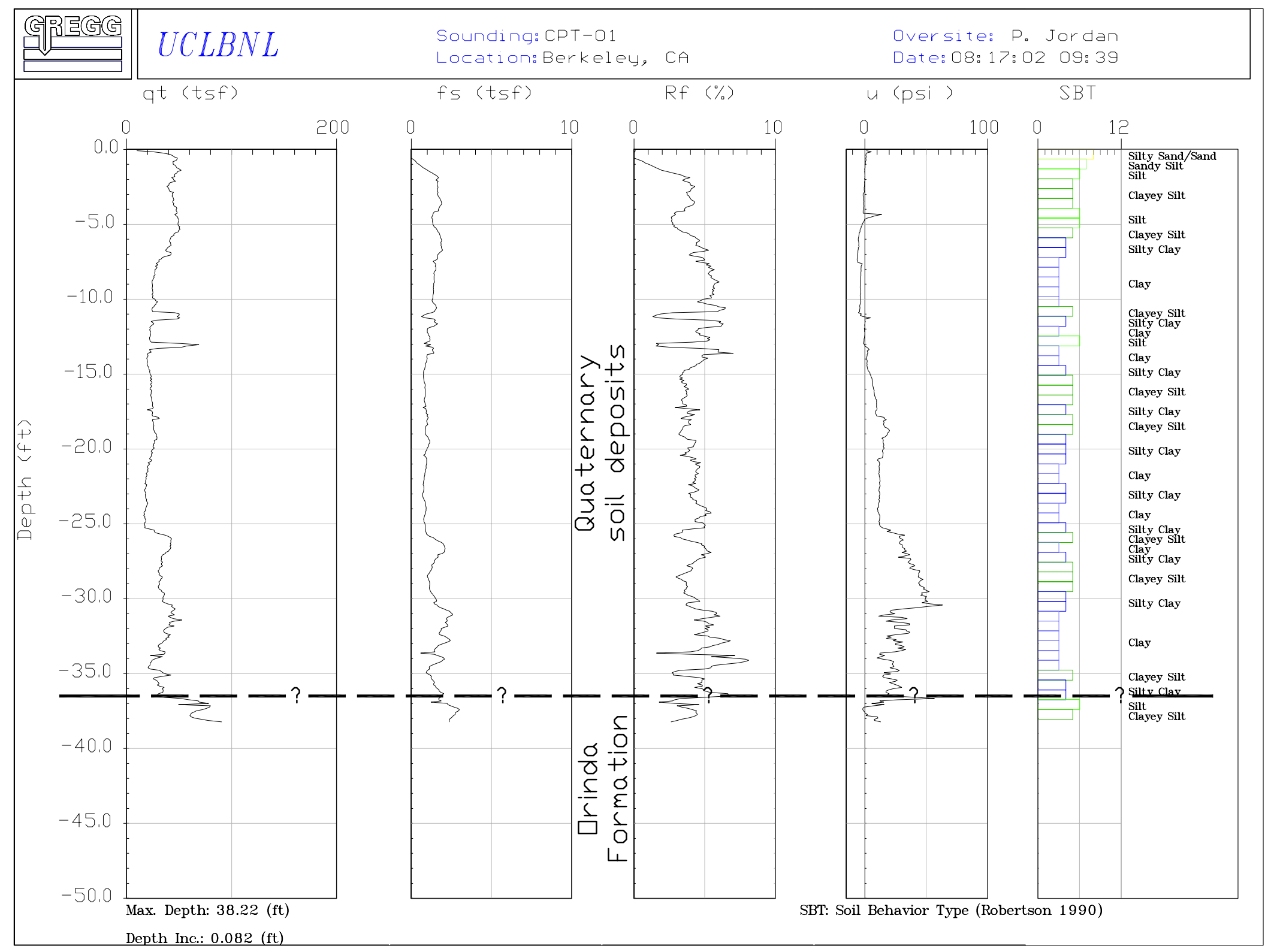




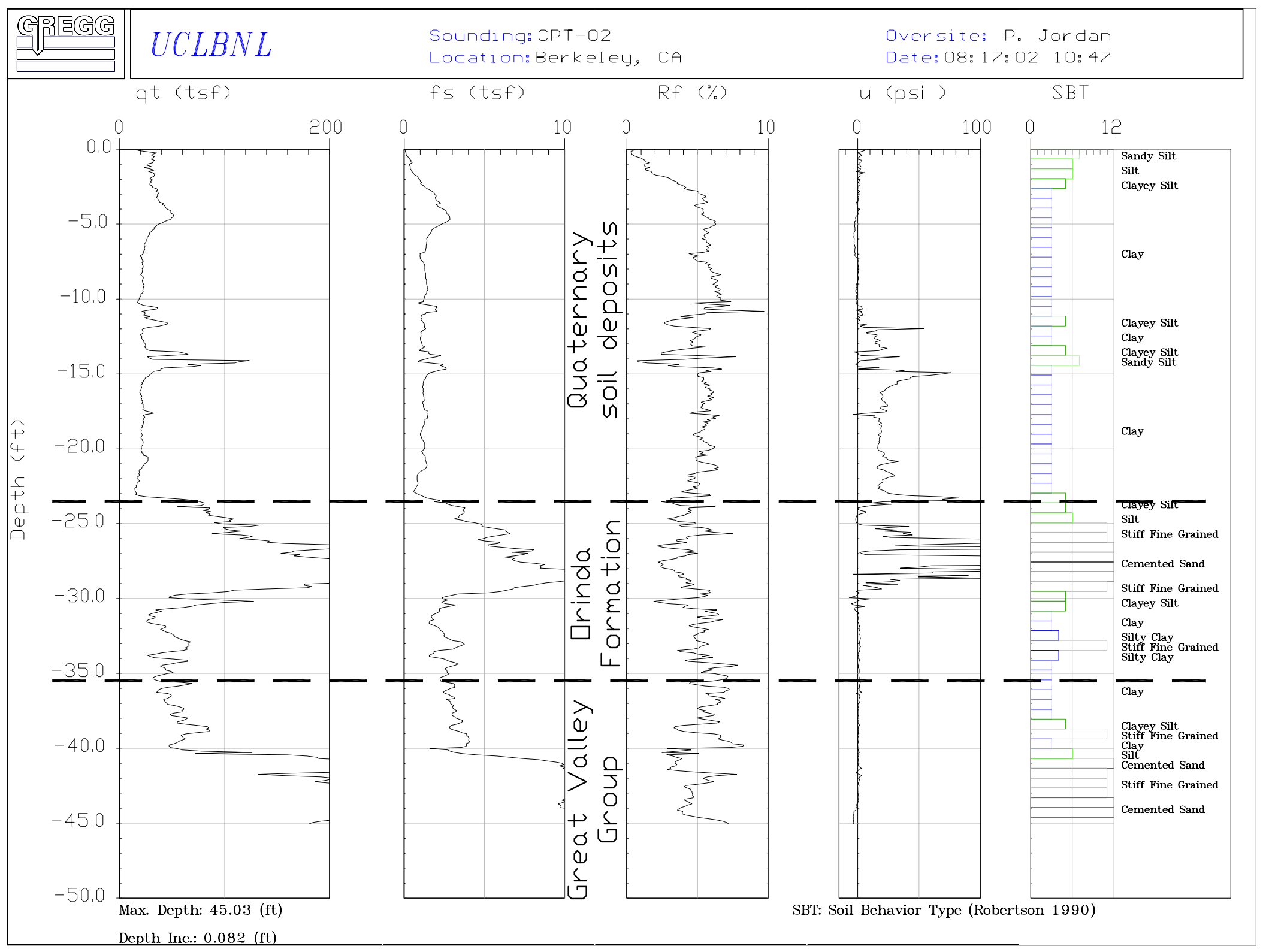




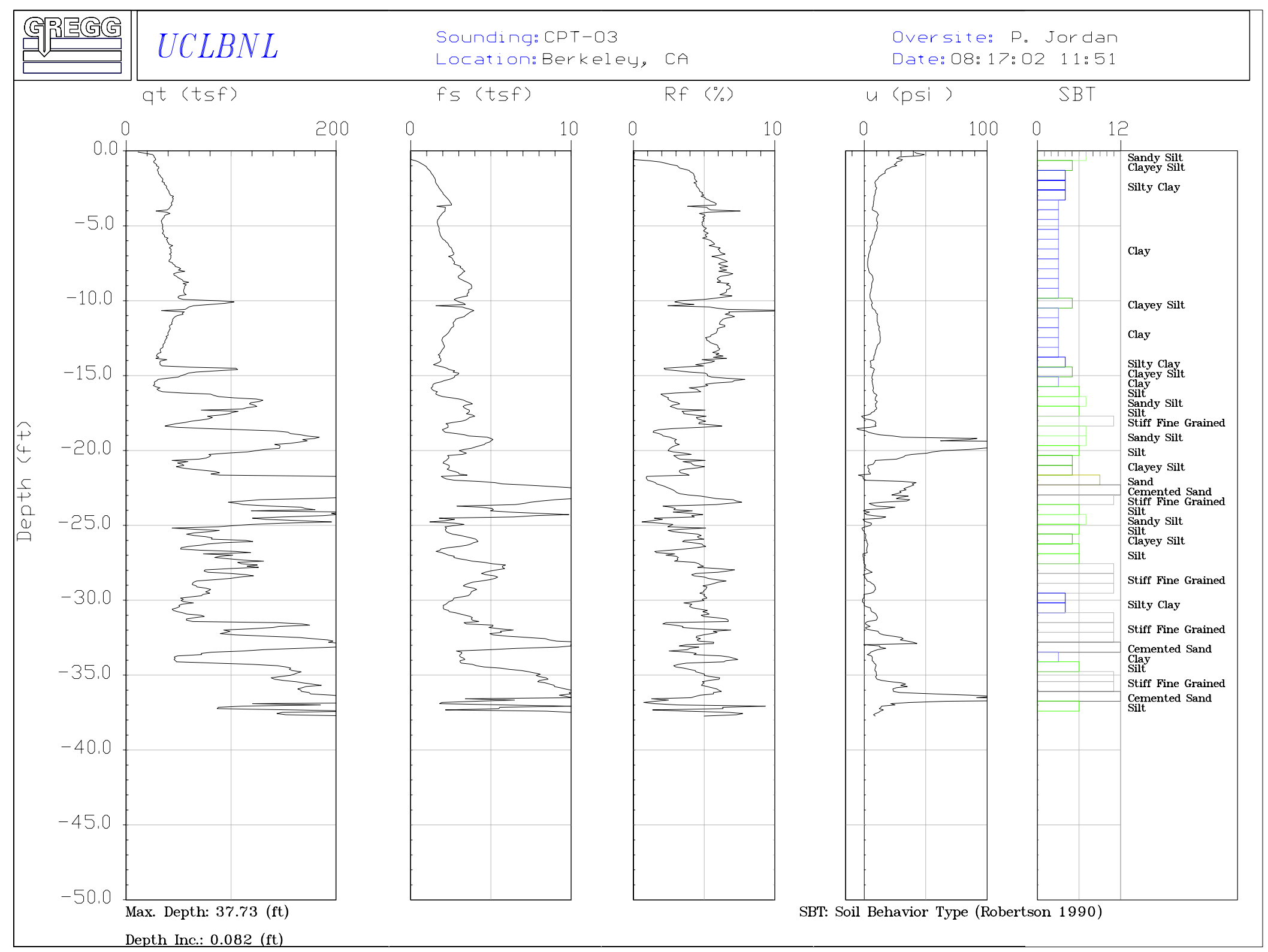




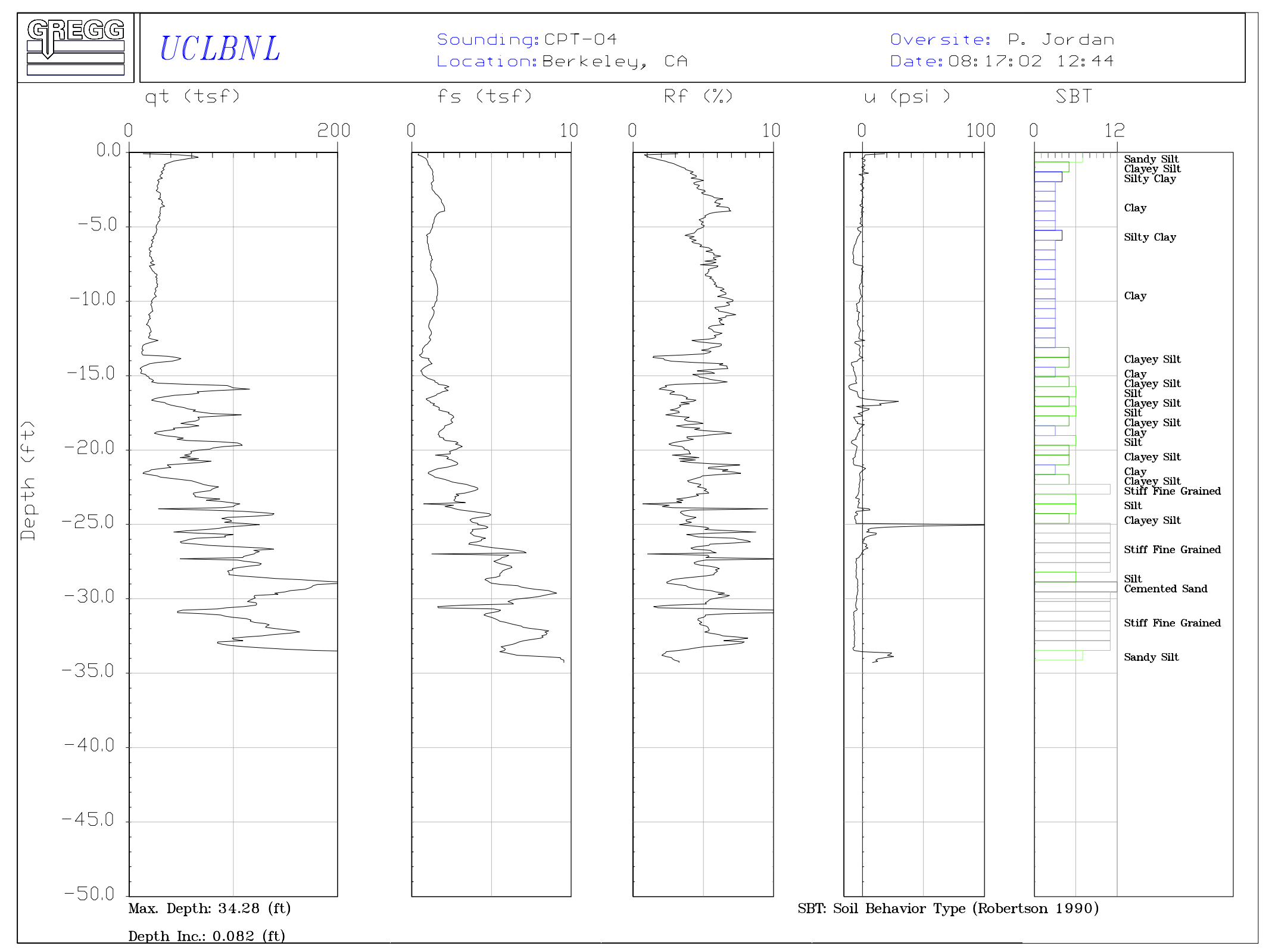




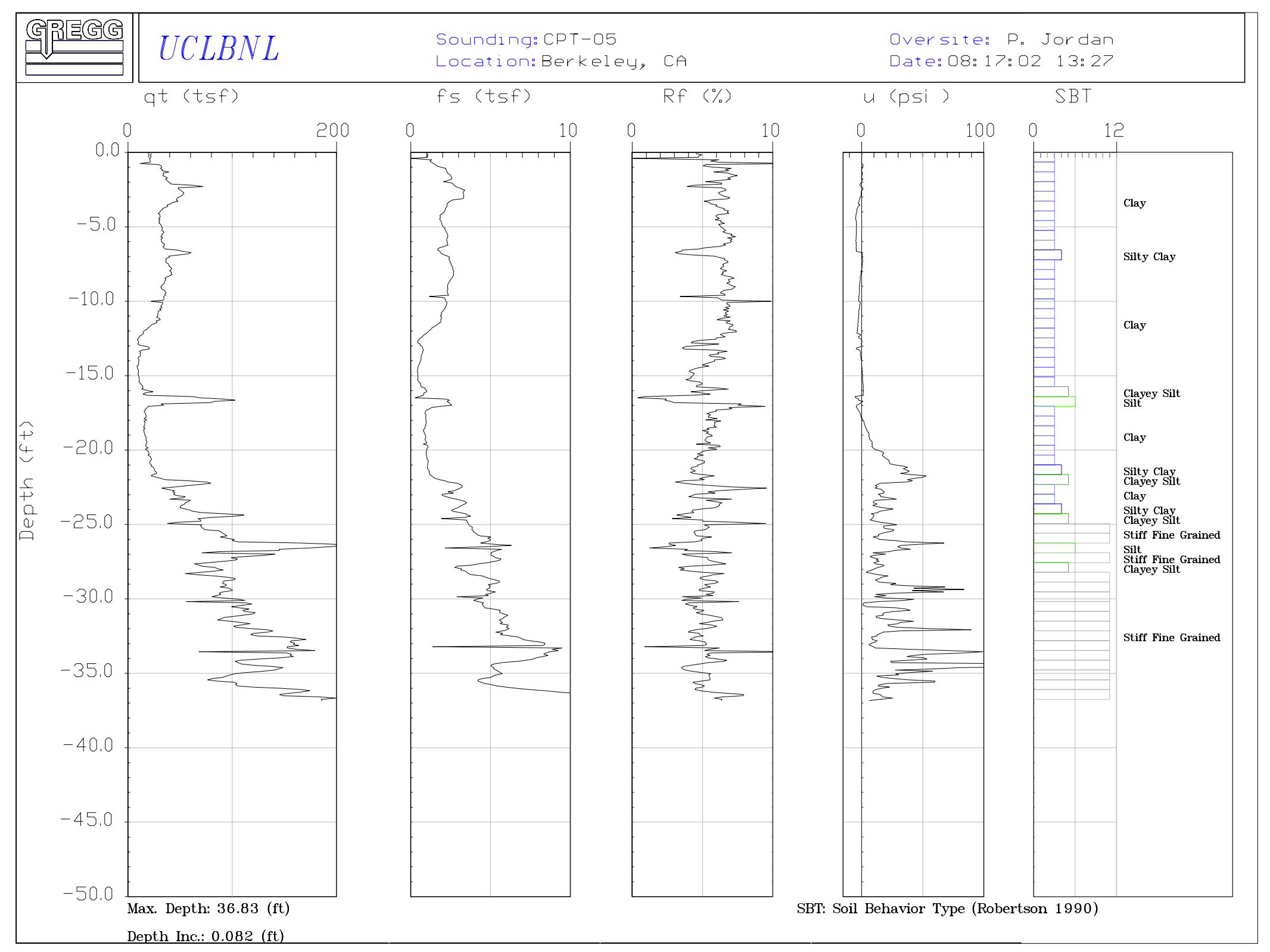




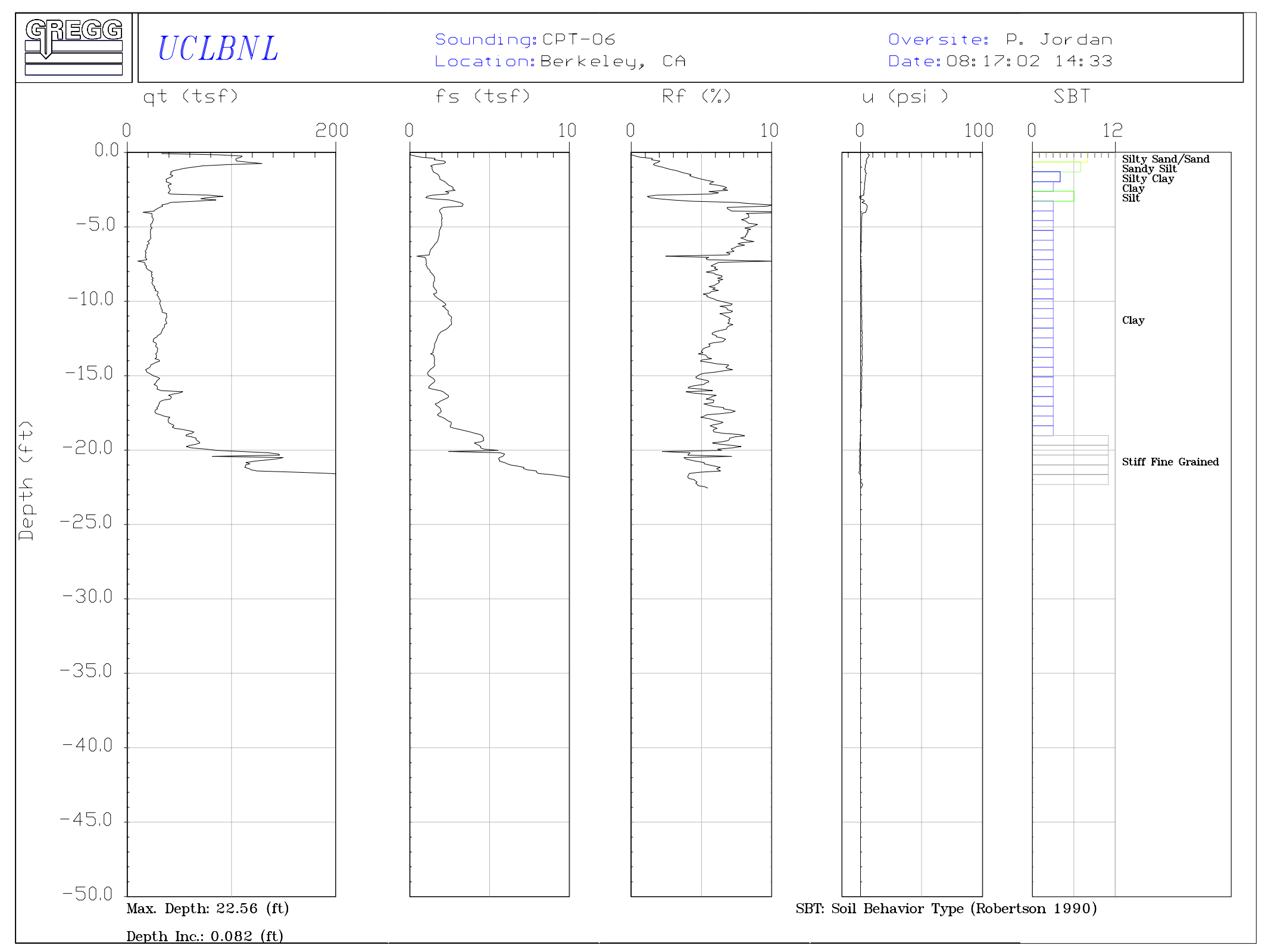


APPENDIX 3: Boring Logs for Temporary Groundwater Sampling Points SB31-02-1 to SB31-02-7 and SB31-03-1 to SB31-03-4 


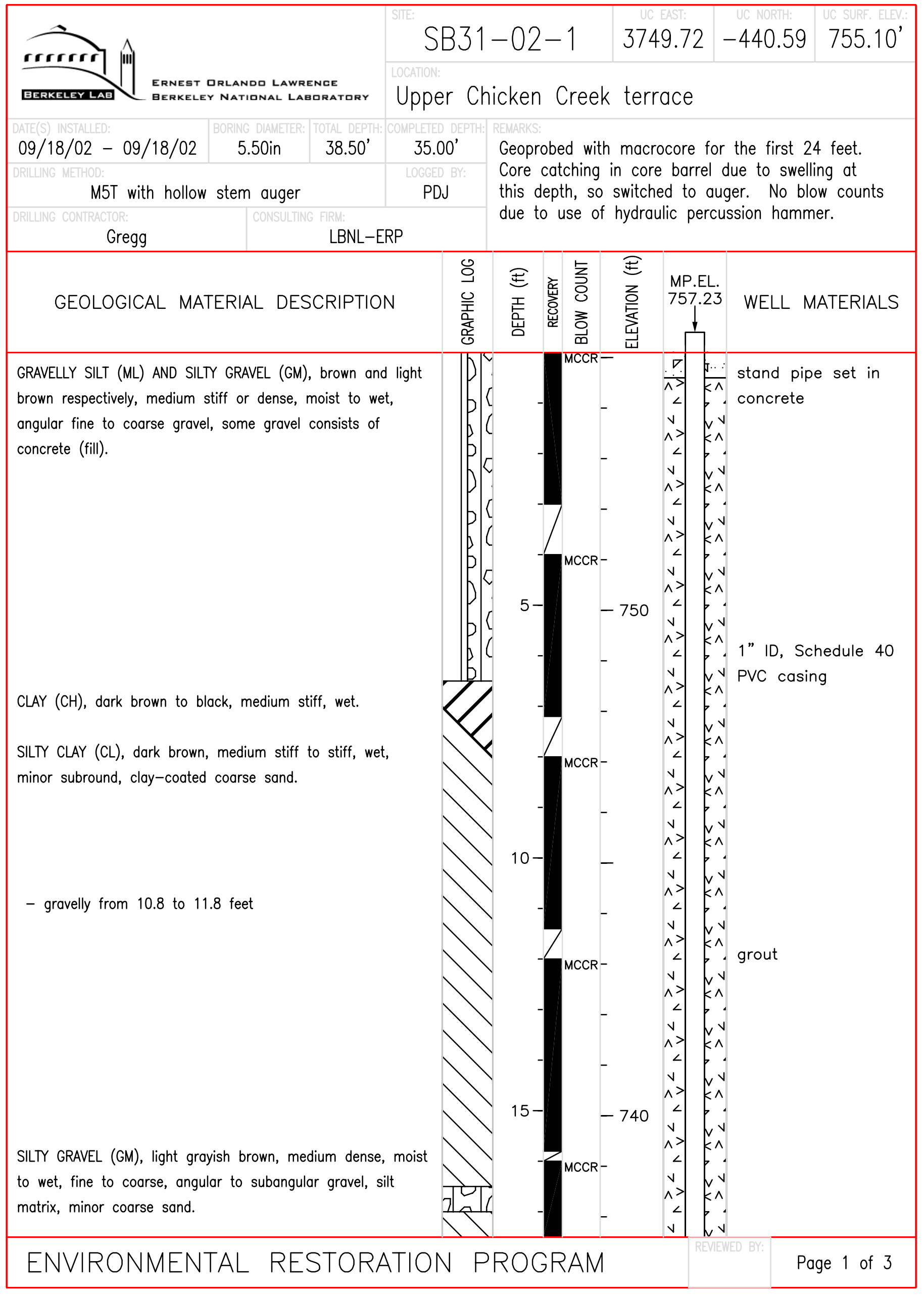




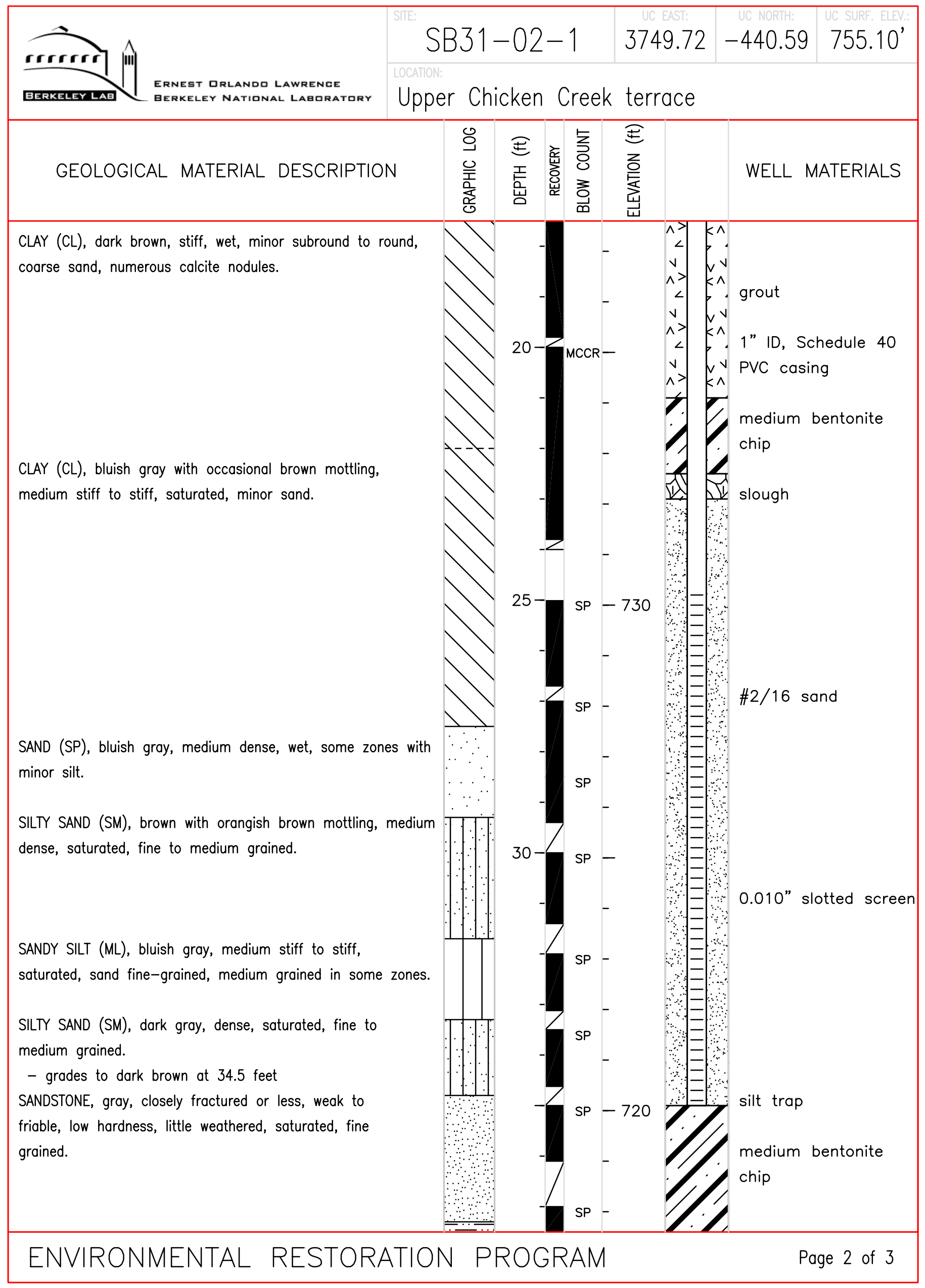




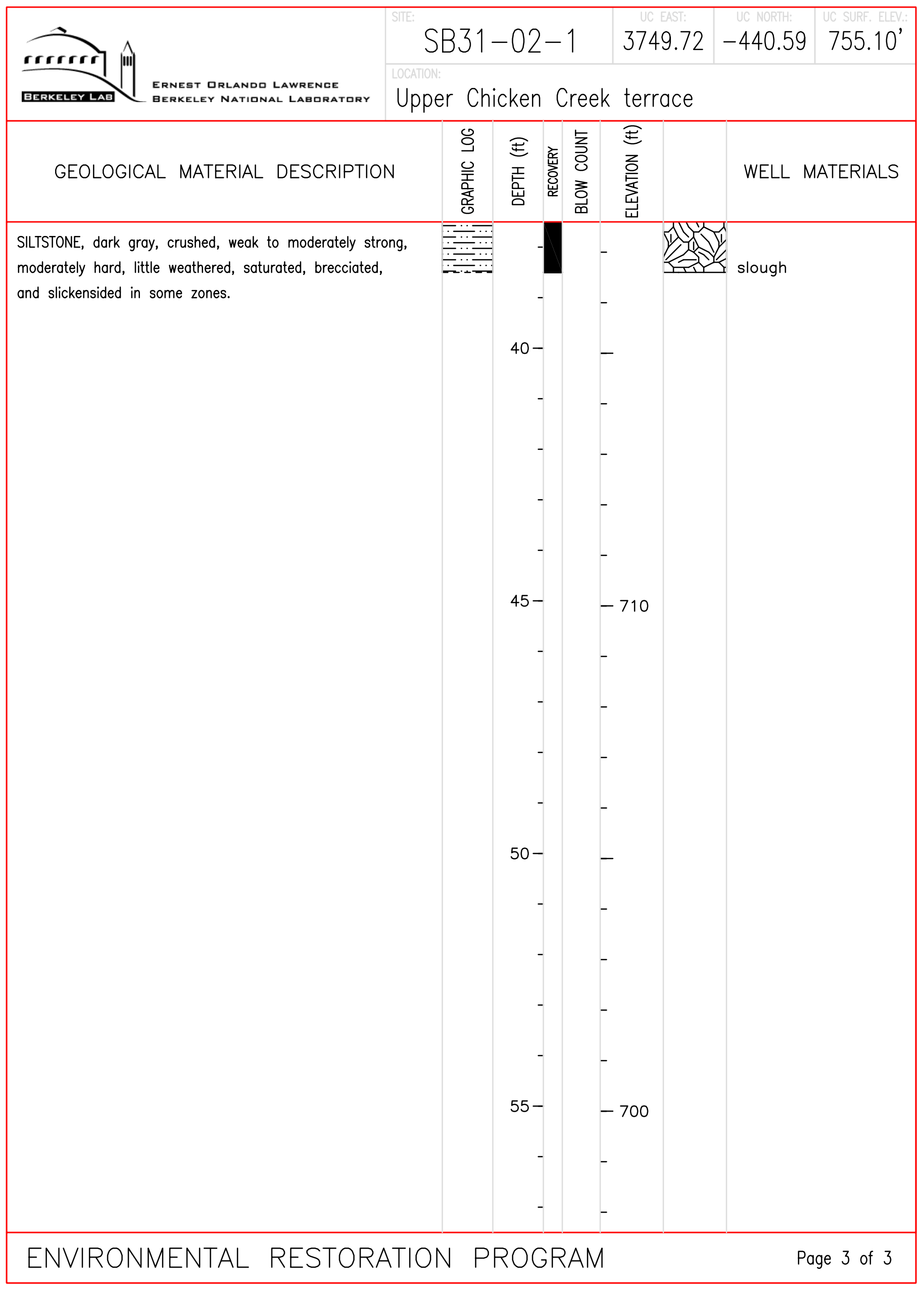




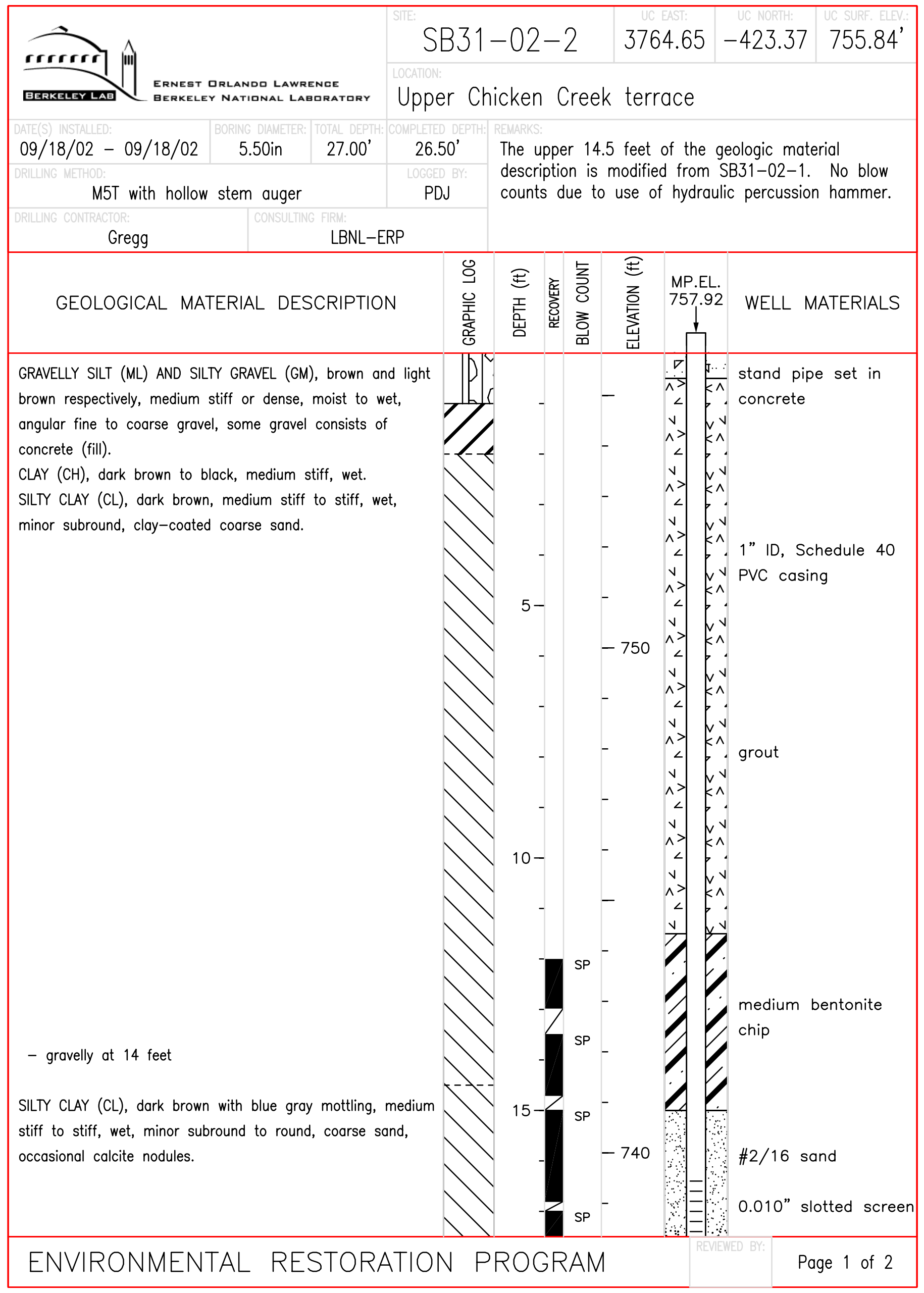




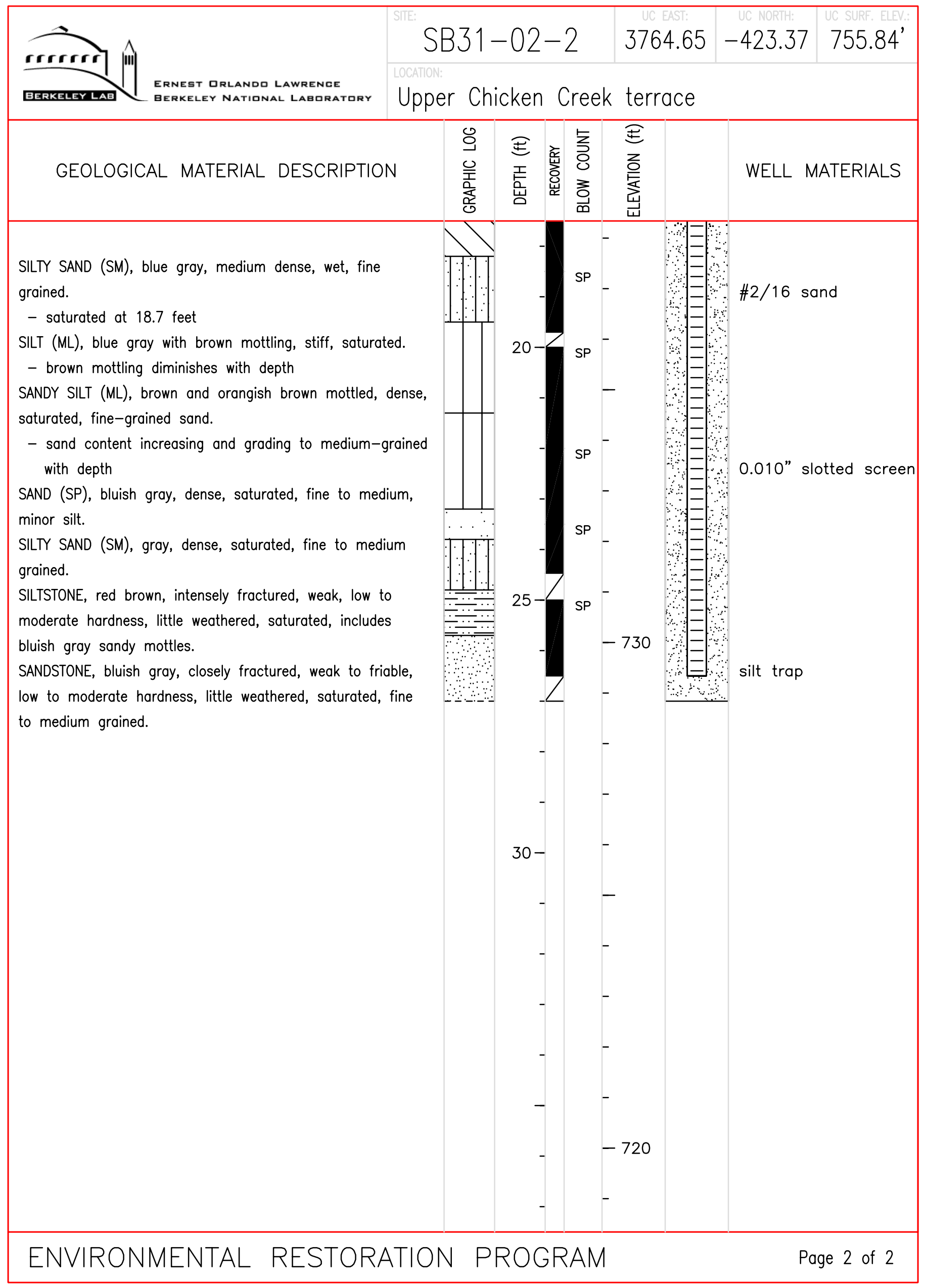




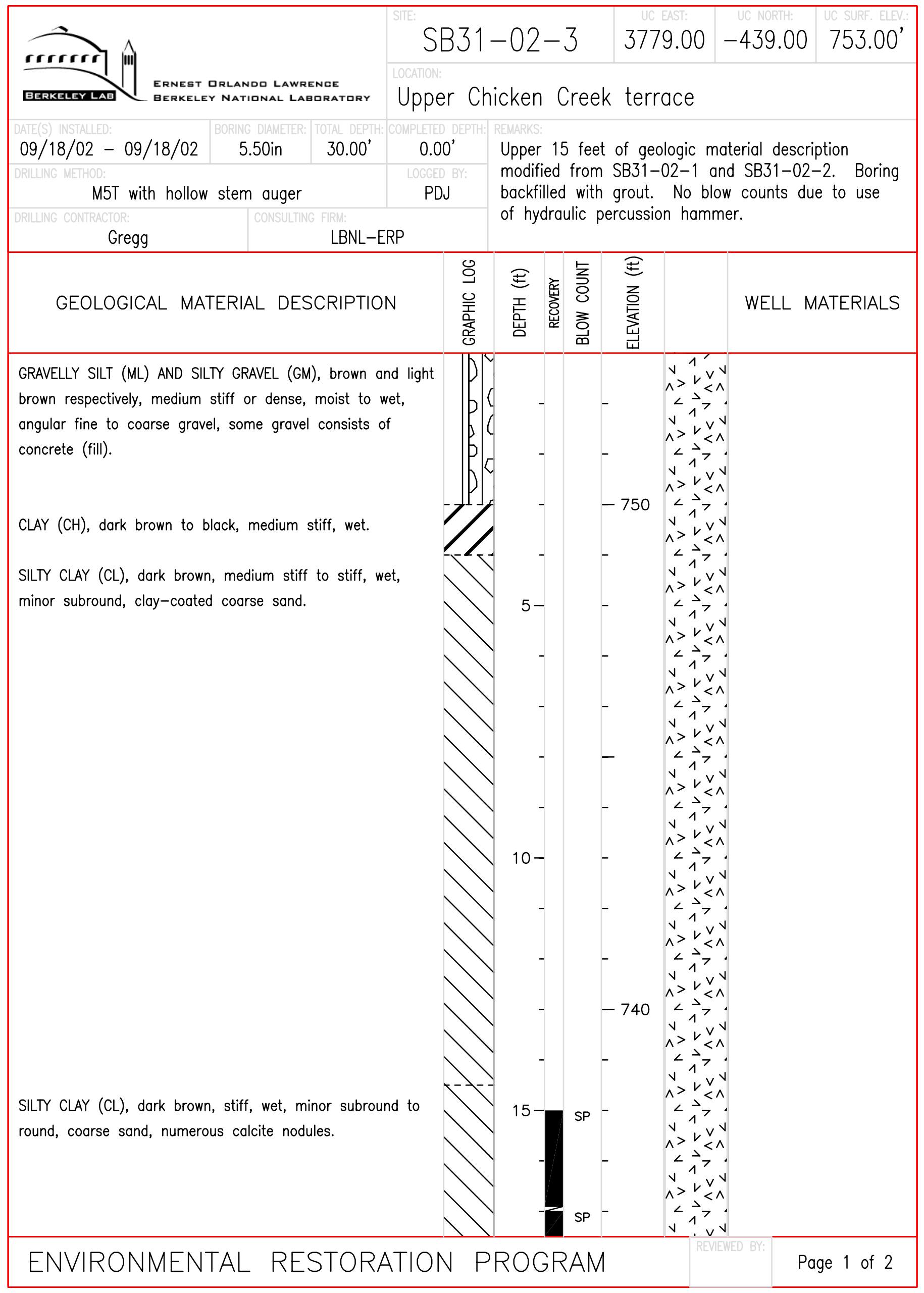




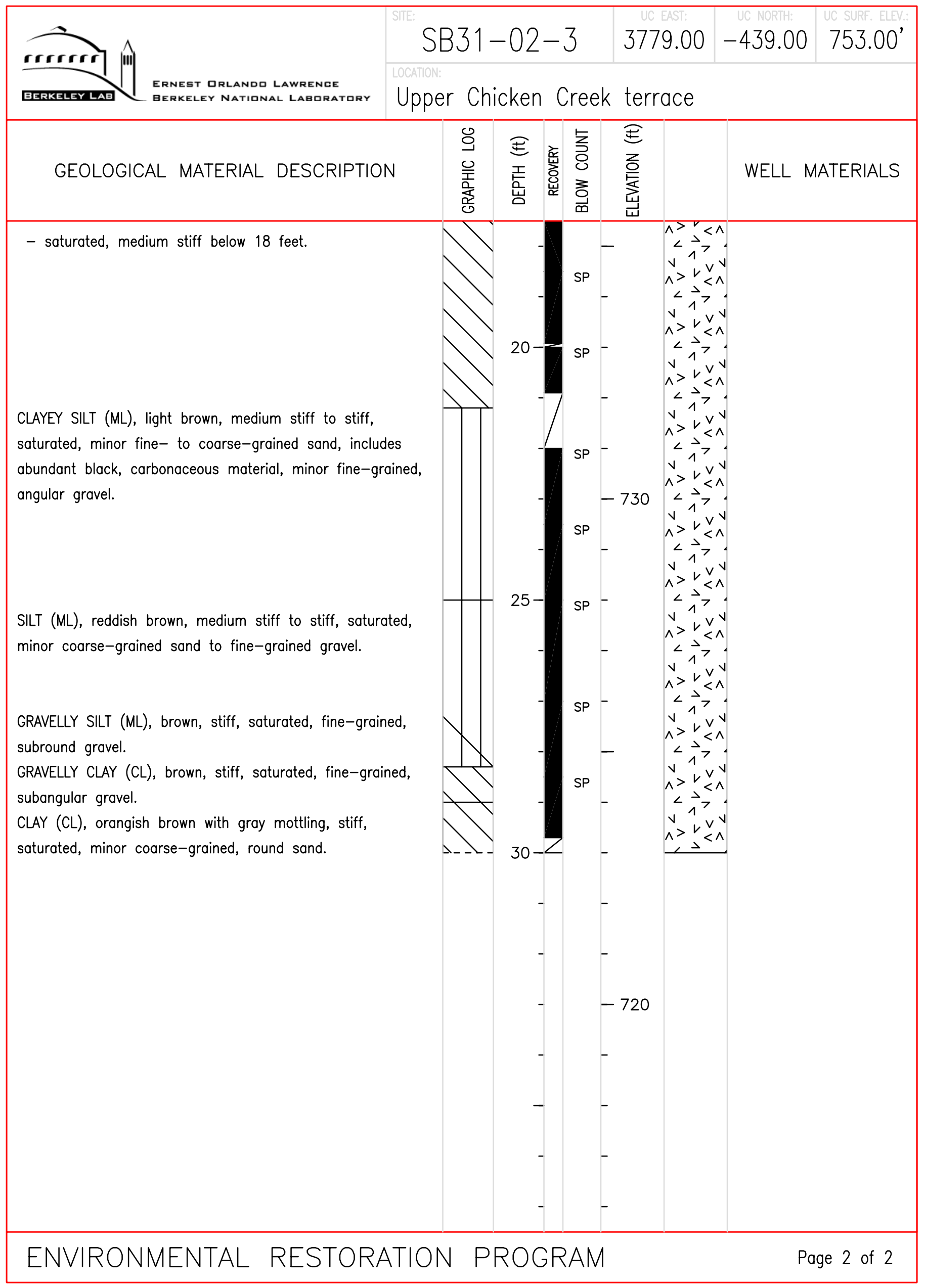




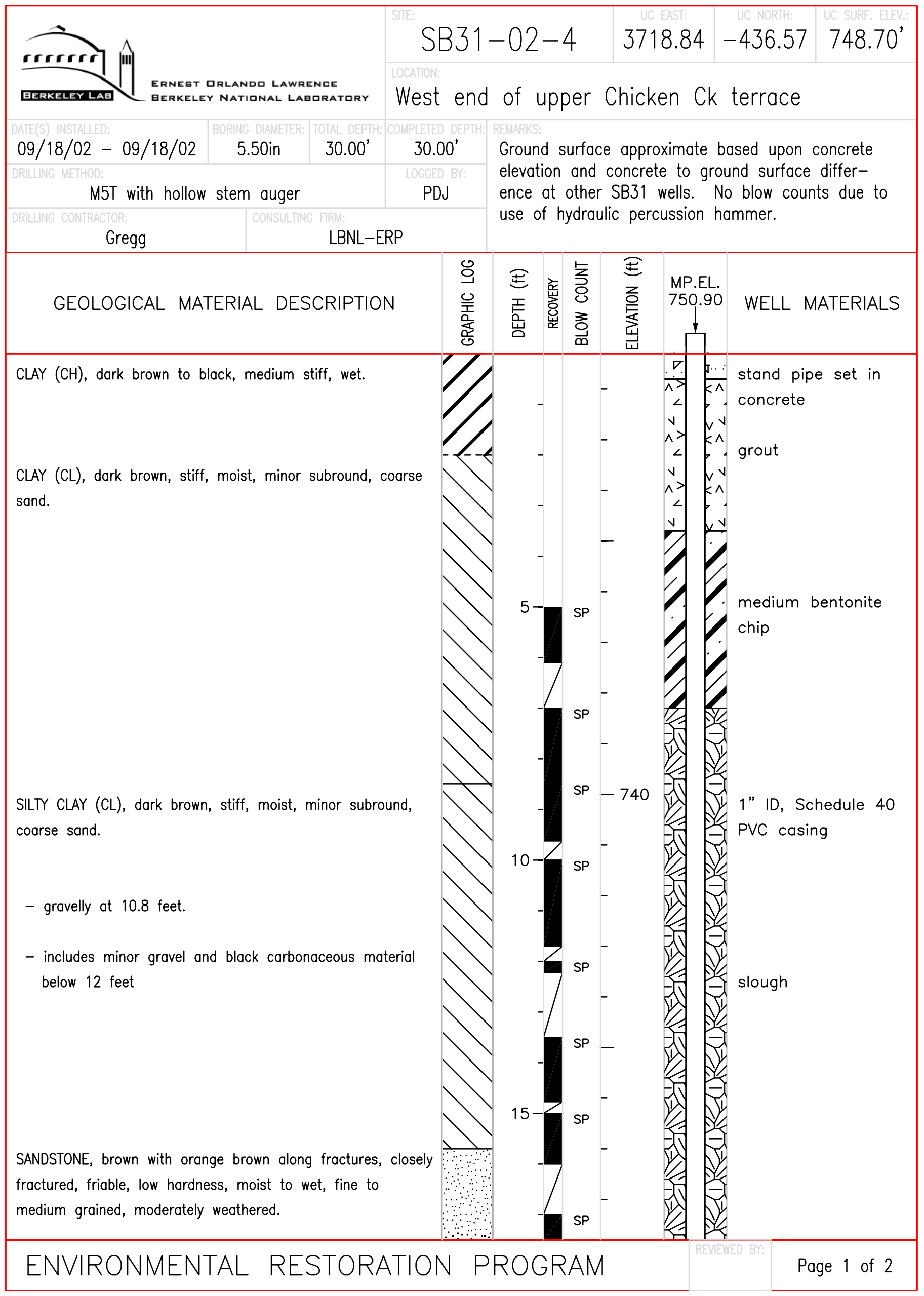




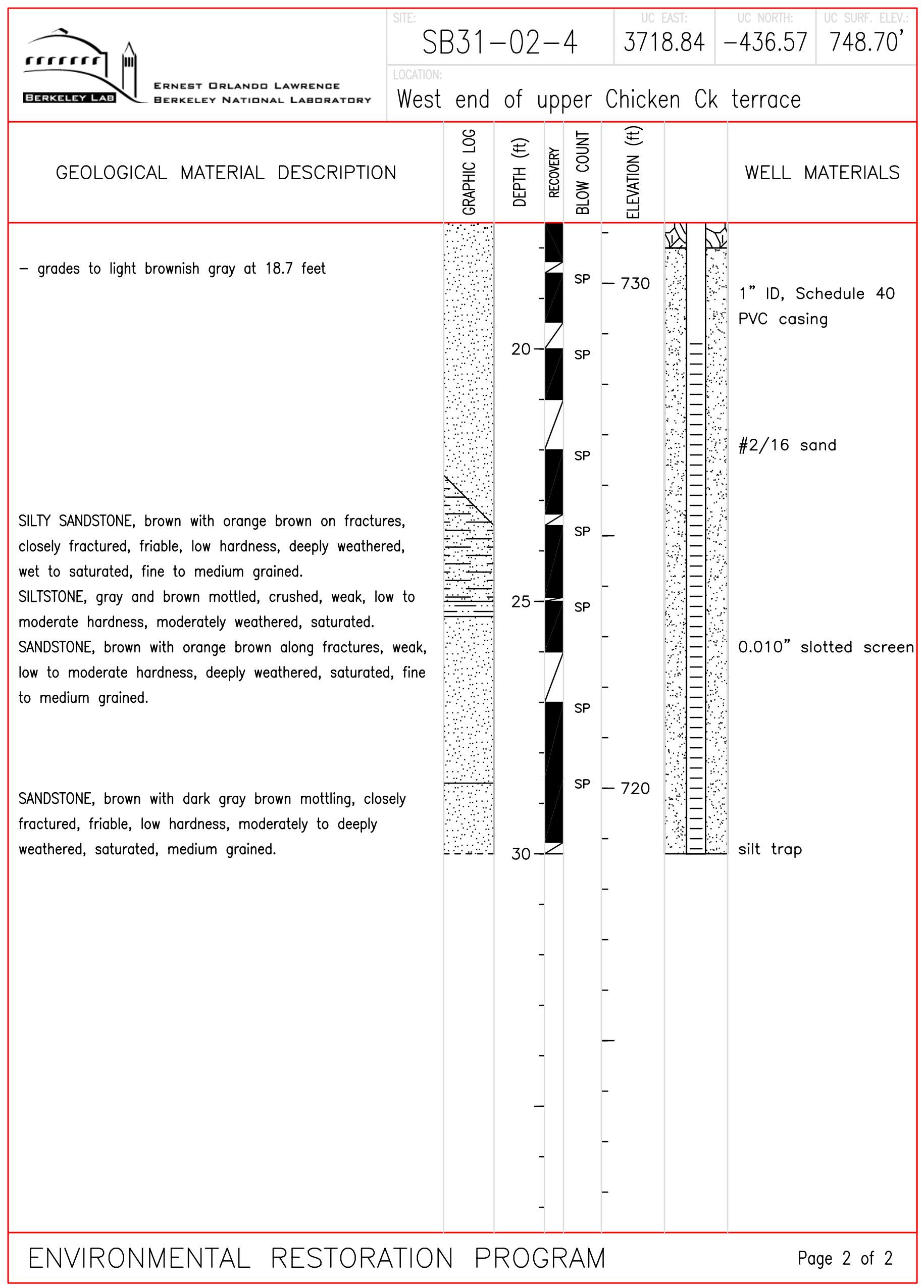




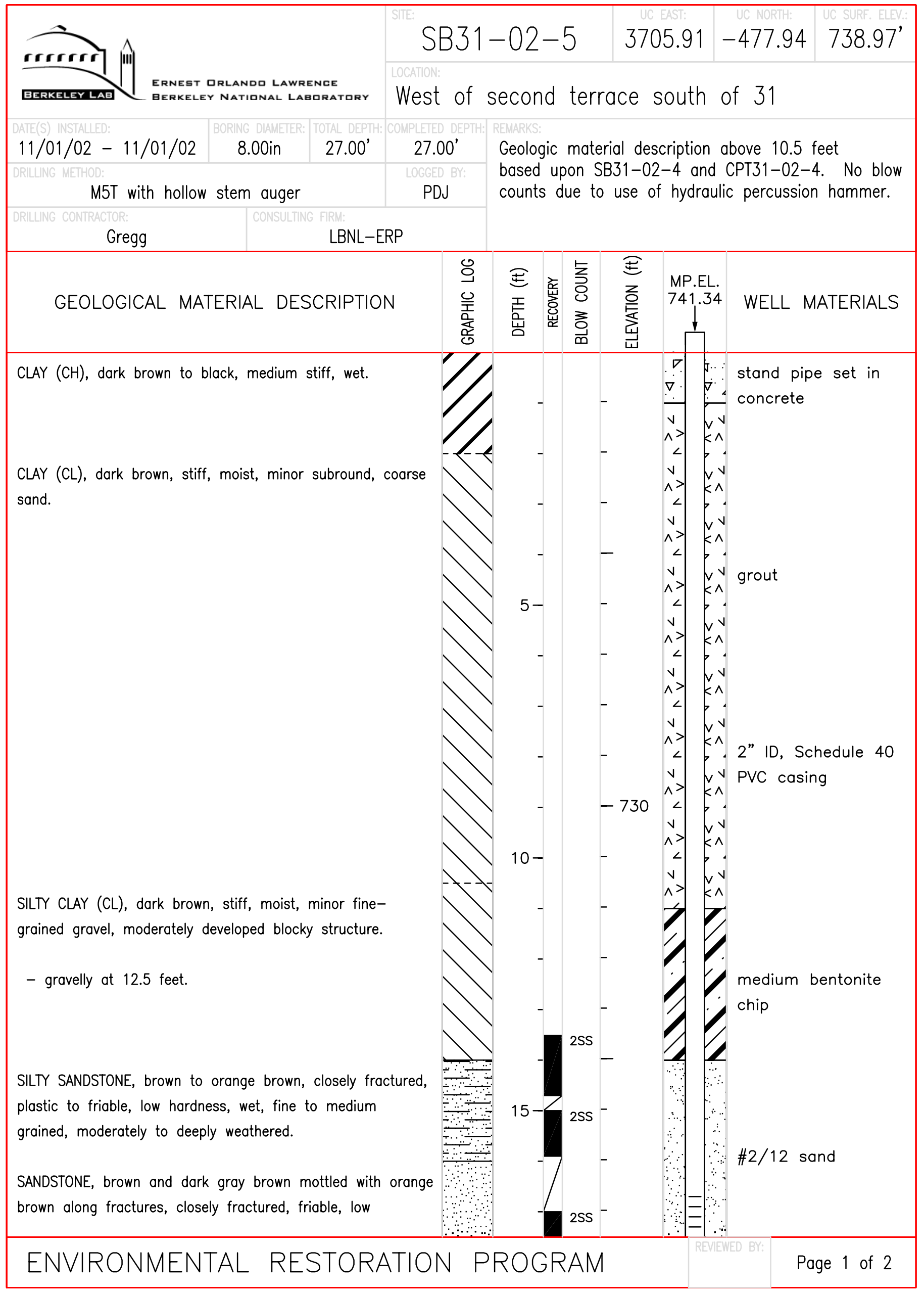




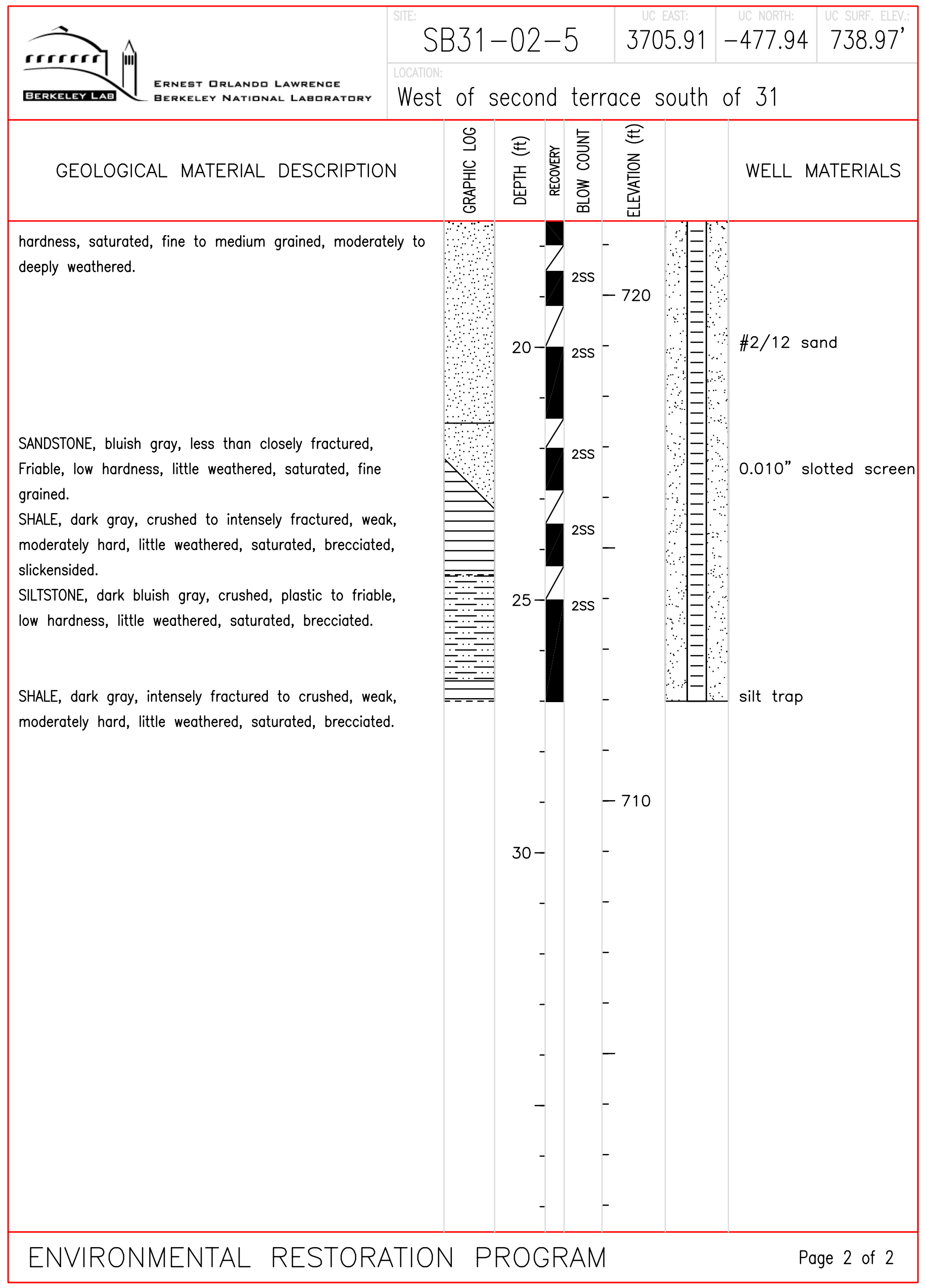




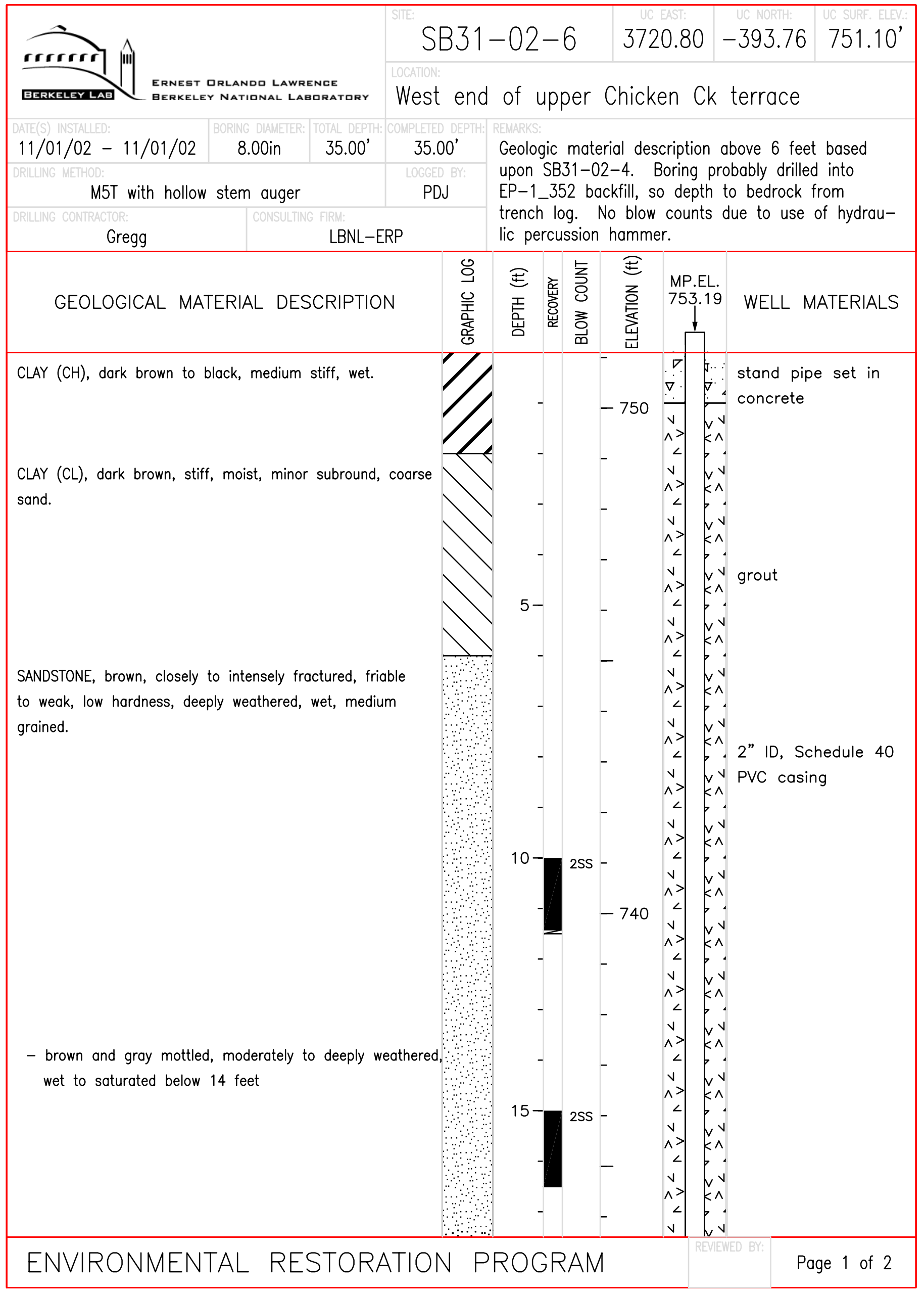




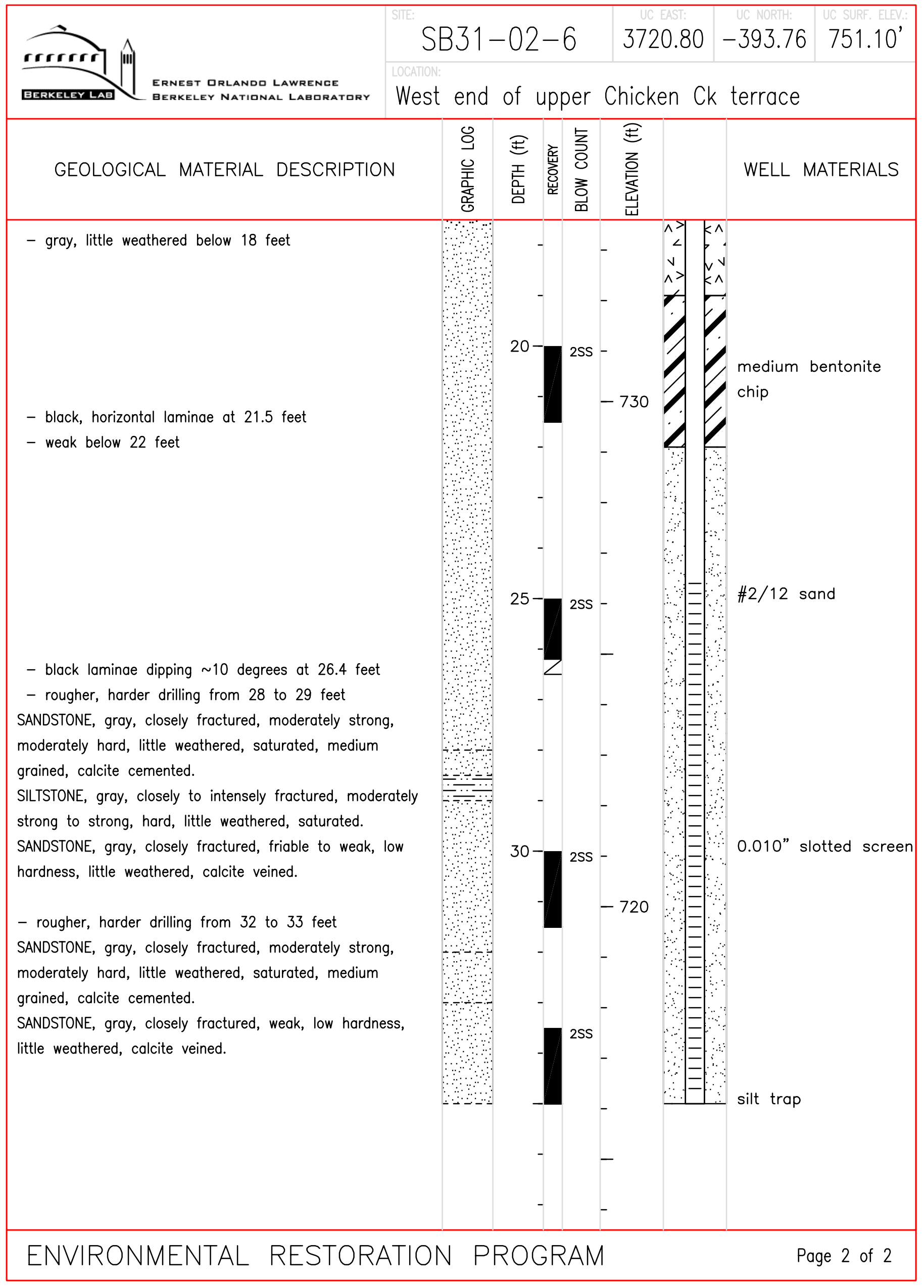




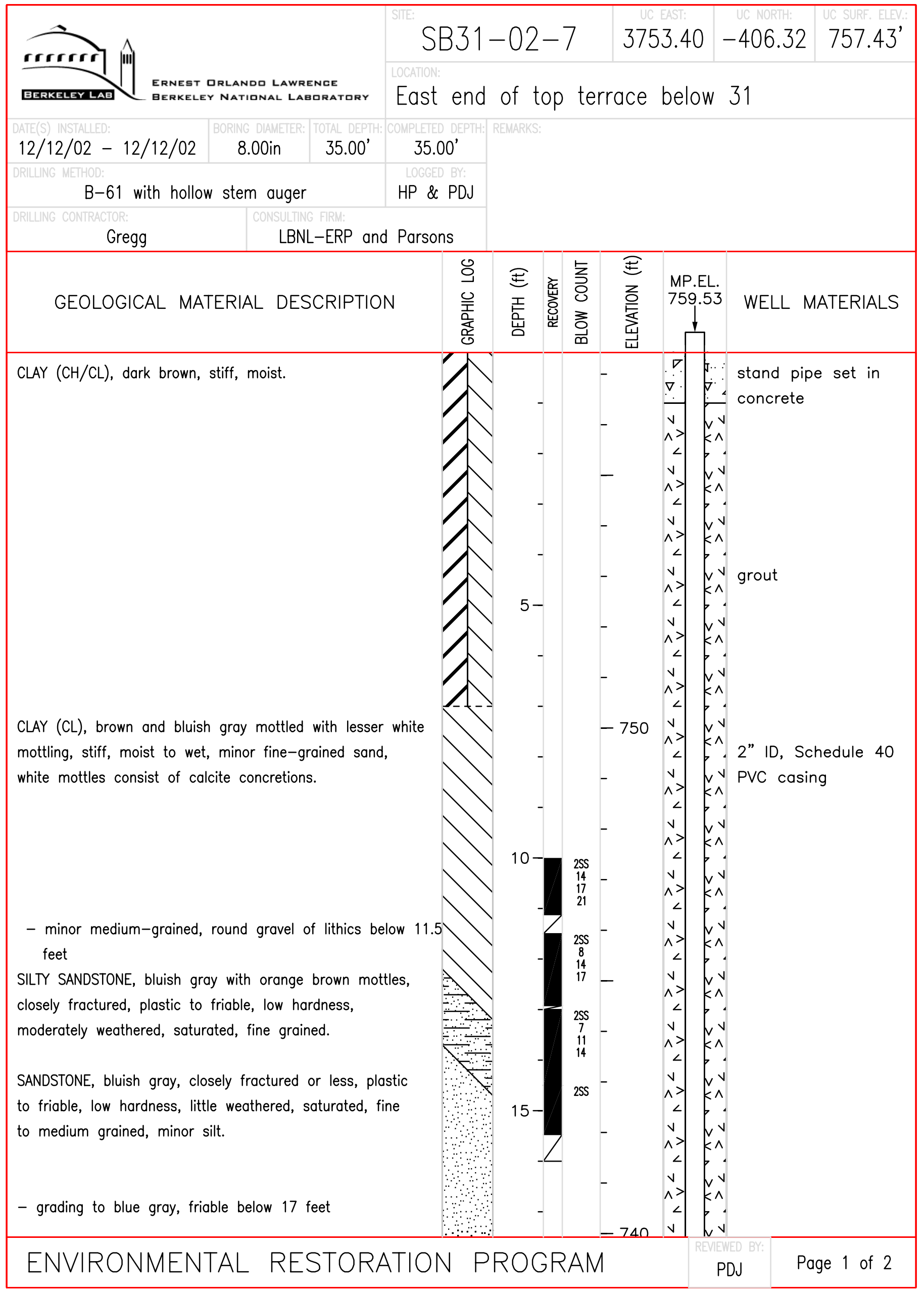




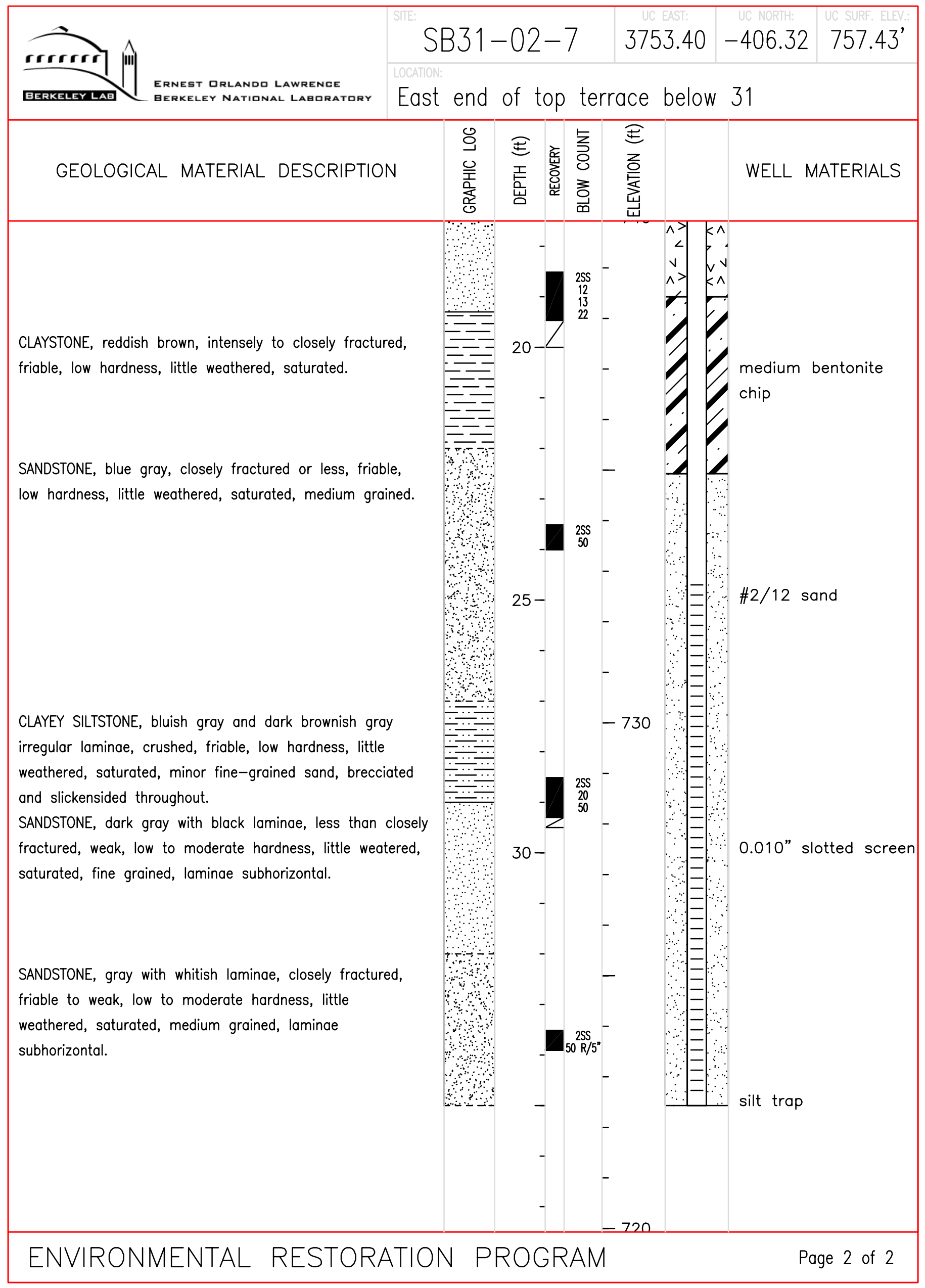




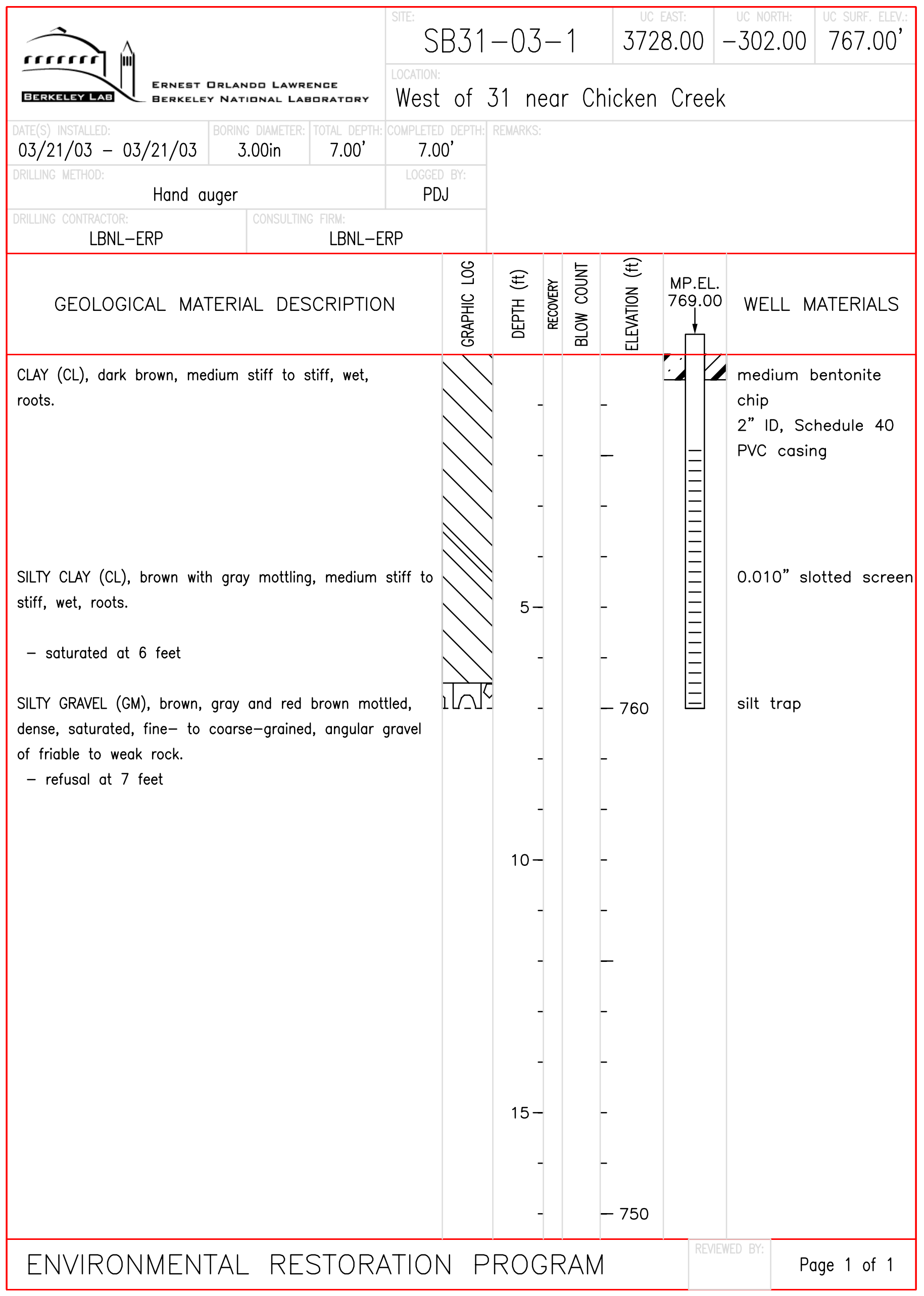




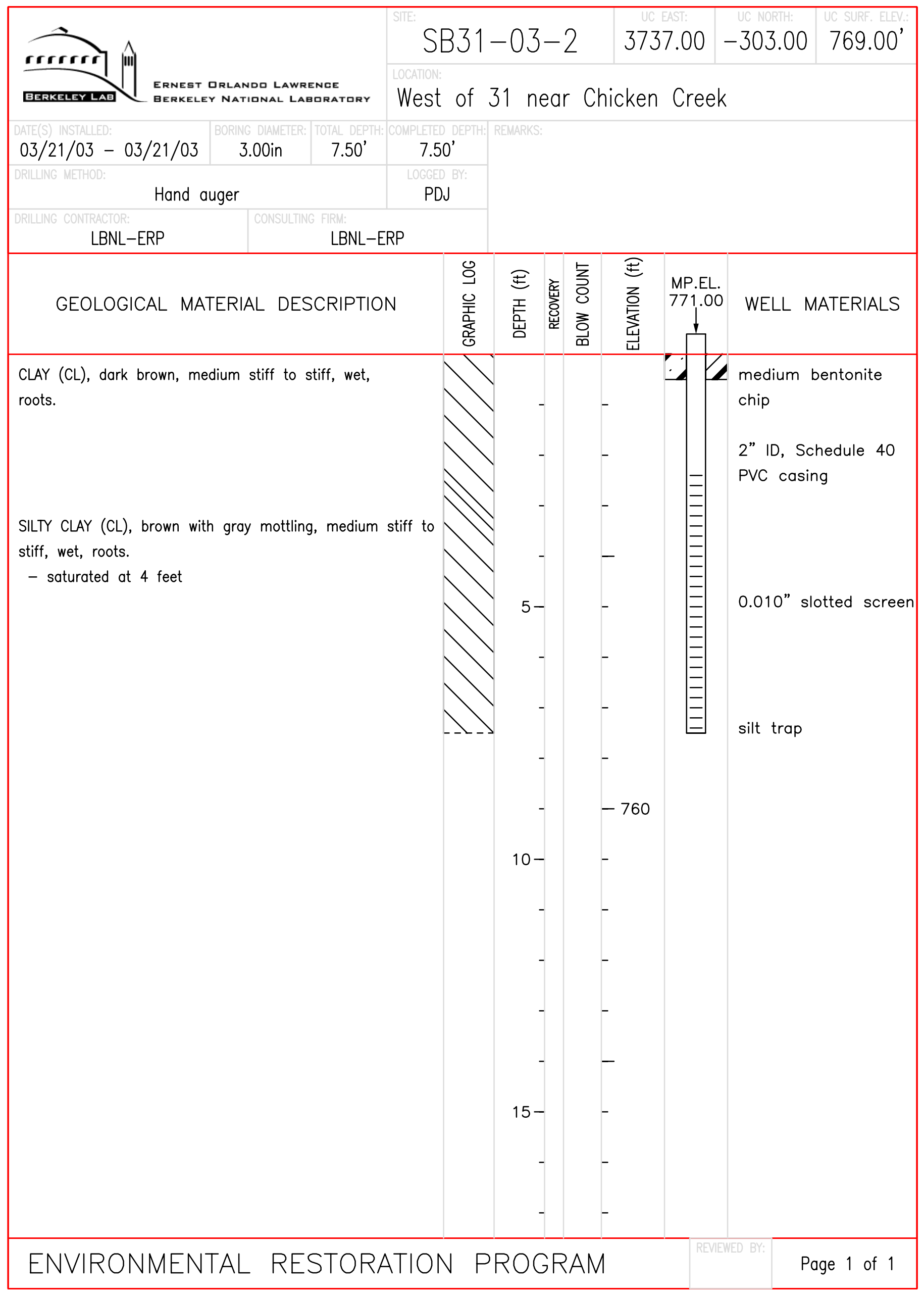




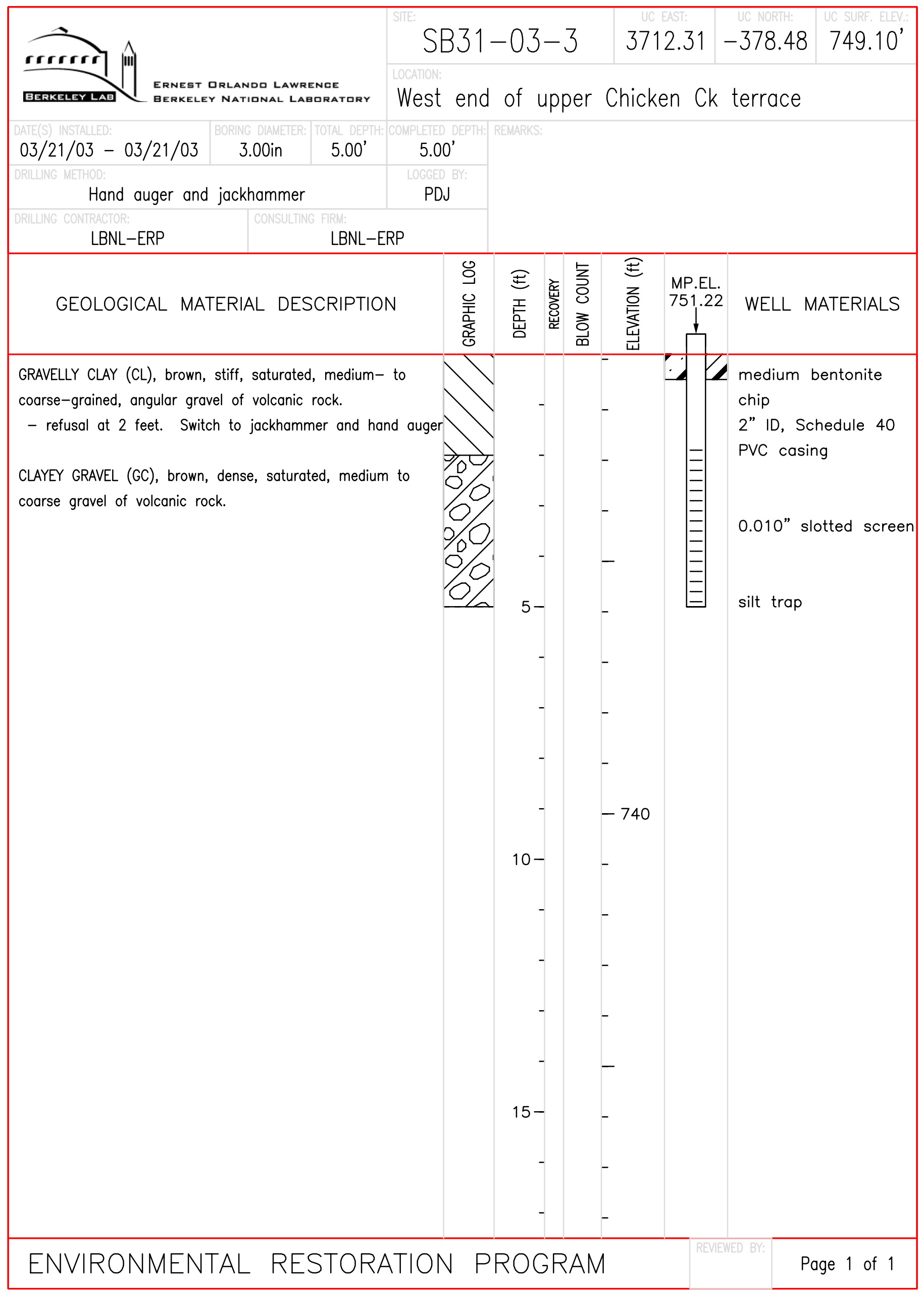




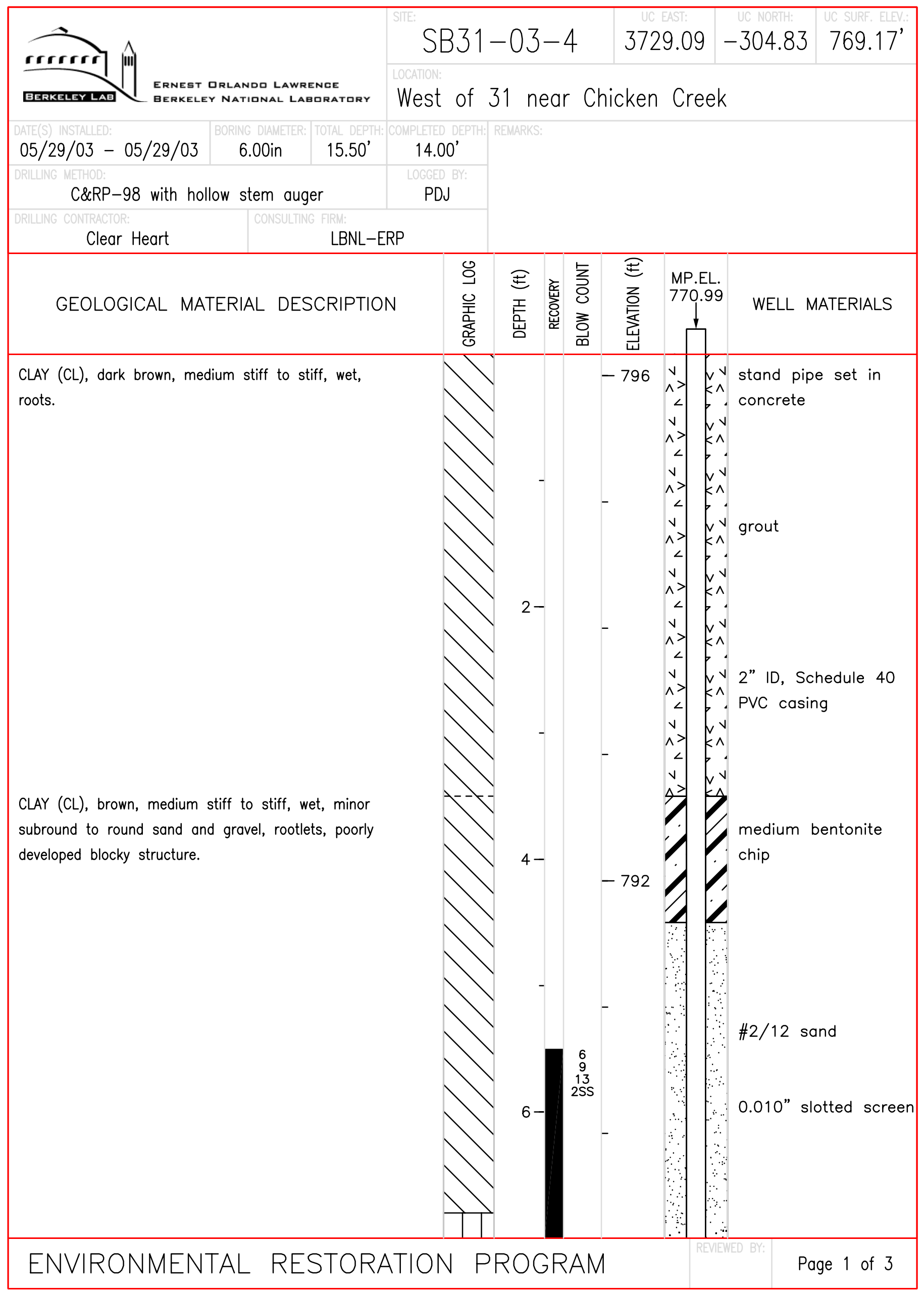




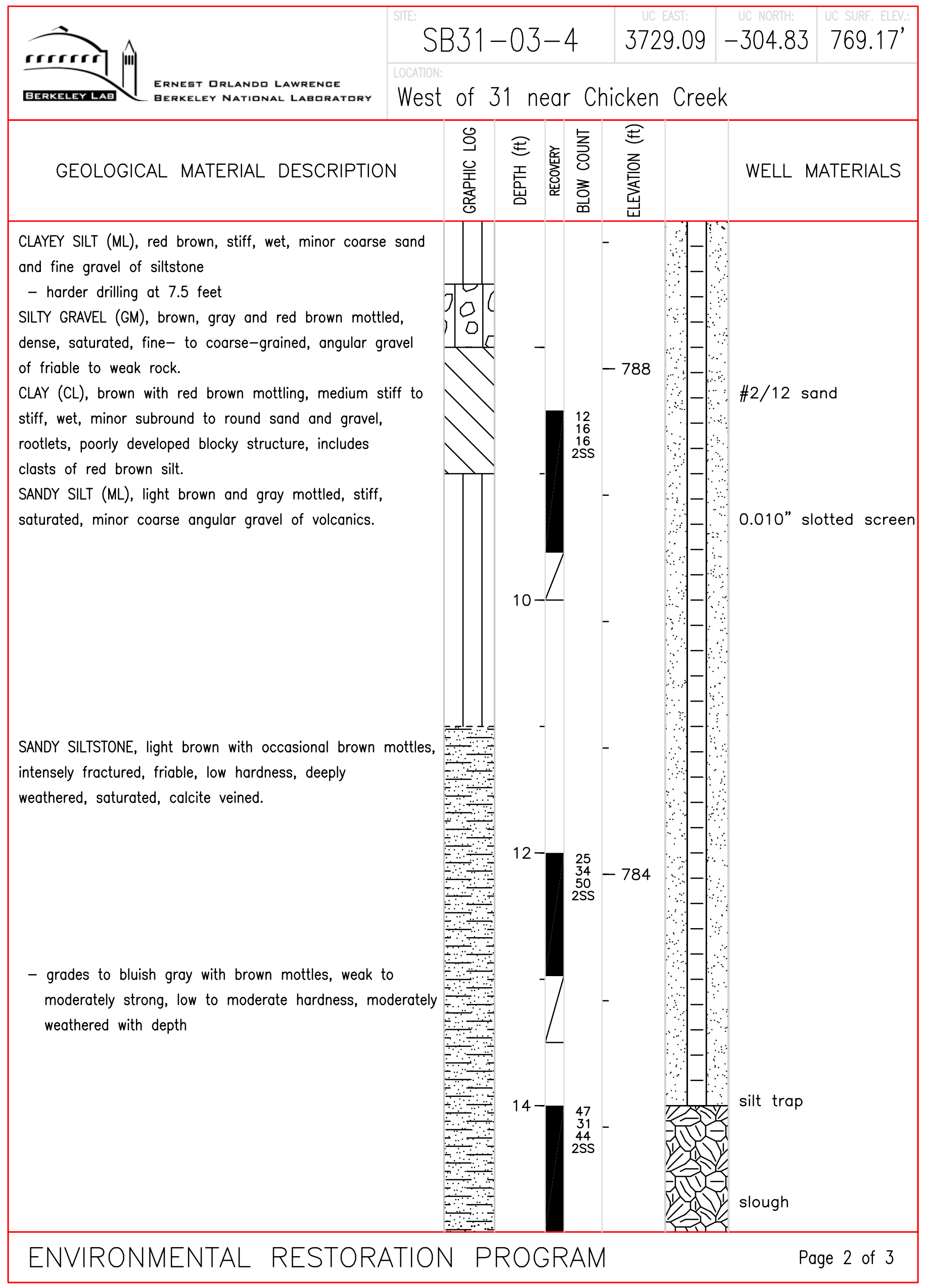




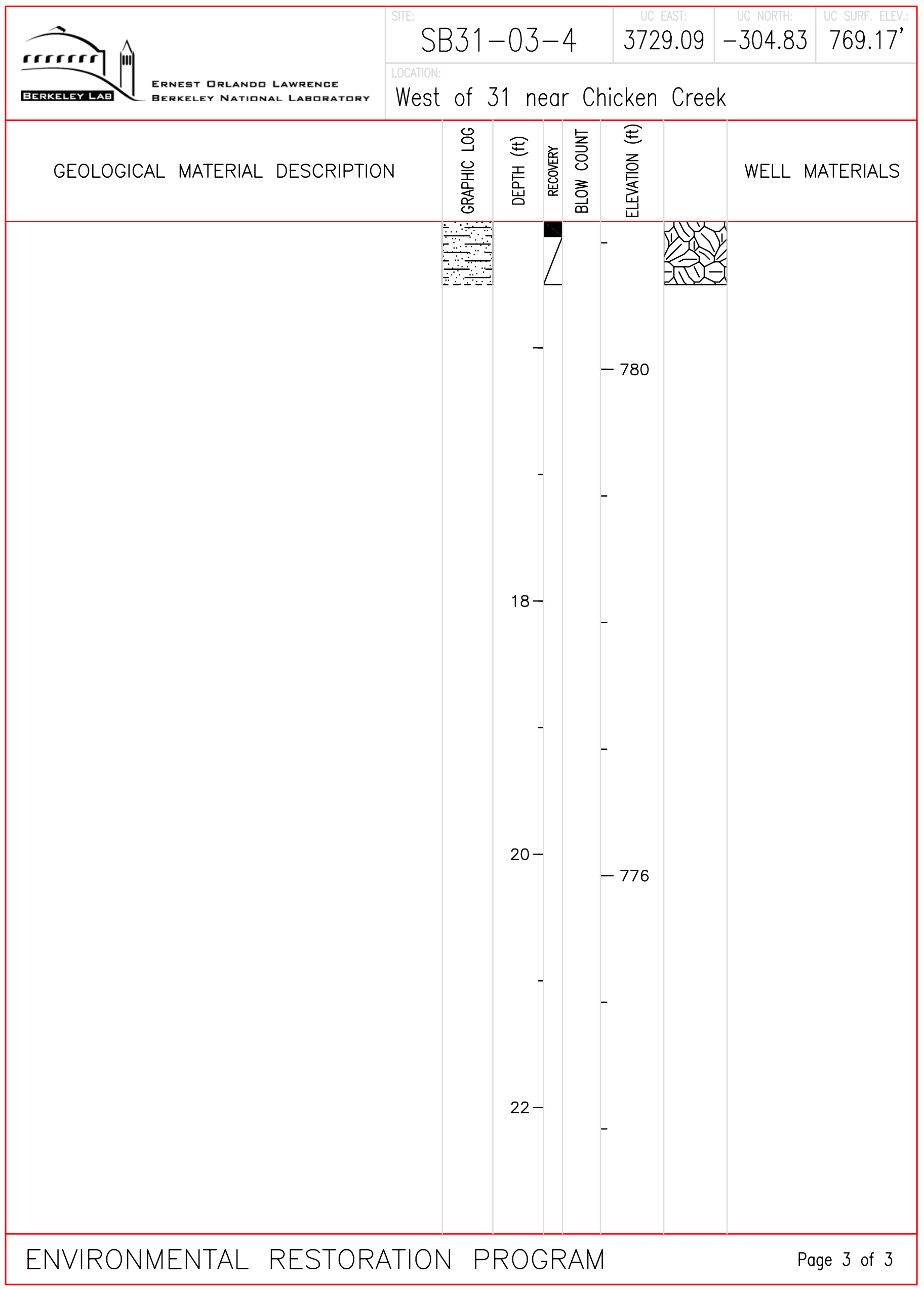

